\title{
RESEARCH FRONTIERS IN SPELEOGENESIS. DOMINANT PROCESSES, HYDROGEOLOGICAL CONDITIONS AND RESULTING CAVE PATTERNS
}

\author{
NOVA PODROČJA SPELEOGENETSKIH RAZISKAV: POVEZAVA \\ MED HIDROGEOLOŠKIMI RAZMERAMI, PREVLADUJOČIMI \\ PROCESI IN TIPI JAM
}

\author{
Philippe AUDRA $^{1} \&$ Arthur N. PALMER ${ }^{2}$
}

\begin{abstract}
UDC 551.435.84

Philippe Audra \& Arthur N. Palmer: Research frontiers in speleogenesis. Dominant processes, hydrogeological conditions and resulting cave patterns

Speleogenesis is the development of well-organized cave systems by fluids moving through fissures of a soluble rock. Epigenic caves induced by biogenic $\mathrm{CO}_{2}$ soil production are dominant, whereas hypogenic caves resulting from uprising deep flow not directly connected to adjacent recharge areas appear to be more frequent than previously considered. The conceptual models of epigenic cave development moved from early models, through the "four-states model" involving fracture influence to explain deep loops, to the digital models demonstrating the adjustment of the main flow to the water table. The relationships with base level are complex and cave levels must be determined from the elevation of the vadose-phreatic transitions. Since flooding in the epiphreatic zone may be important, the top of the loops in the epiphreatic zone can be found significantly high above the base level. The term Paragenesis is used to describe the upward development of conduits as their lower parts fill with sediments. This process often records a general baselevel rise. Sediment influx is responsible for the regulation of long profiles by paragenesis and contributes to the evolution of profiles from looping to water table caves. Dating methods allow identification of the timing of cave level evolution. The term Ghost-rock karstification is used to describe a 2-phase process of speleogenesis, with a first phase of partial solution of rock along fractures in low gradient conditions leaving a porous matrix, the ghost-rock, then a second phase of mechanical removing of the ghost-rock mainly by turbulent flow in high gradient conditions opening the passages and forming maze caves. The first weathering phase can be related either to epigenic infiltration or to hypogenic upflow, especially in marginal areas of sedimentary basins. The vertical pattern of epigenic caves is mainly controlled by timing, geological structure, types of flow and base-level changes. We define several
\end{abstract}

Izvleček UDK 551.435.84

Philippe Audra \& Arthur N. Palmer: Nova področja speleogenetskih raziskav: Povezava med hidrogeološkimi razmerami, prevladujočimi procesi in tipi jam

Speleogeneza je razvoj dobro (samo)organiziranih jamskih sistemov, ko podzemna voda vzdolž toka raztaplja stene razpok. Najbolj poznane so epigene jame v karbonatih, kjer je poglavitni vir kemične agresivnosti pedogeni $\mathrm{CO}_{2}$. Bolj pogoste, kot se je v preteklosti domnevalo, so hipogene jame, ki nastanejo $\mathrm{z}$ dviganjem globokega toka in niso neposredno povezane $\mathrm{z}$ lokalnim napajalnim območjem. Prvotni konceptualni modeli razvoja epigenih jam so se preko modela štirih stanj, ki speleogenezo pojasnjuje s frekvenco prevodnih razpok, razvili do računalniških modelov, ki pojasnijo prilagoditev glavnega toka freatični površini. Povezava jamskih sistemov s položajem erozijske baze ni enostavna, saj moramo pri interpretaciji upoštevati višino prehoda iz freatične $\mathrm{v}$ vadozno cono. Zaradi visokih poplav $\mathrm{v}$ epifreatični coni so lahko temena jamskih zavojev visoko nad erozijsko bazo. Termin parageneza se uporablja za opis razvoja kanalov od spodaj navzgor, ko se spodnji deli zapolnijo s sedimenti. Ta proces pogosto beleži splošen dvig erozijske baze. Vdor sedimentov je tudi razlog za uravnavanje dolgih profilov s paragenezo in prispeva $\mathrm{k}$ prehodu jam $\mathrm{z}$ zavoji $\mathrm{v}$ navpični ravnini $\mathrm{v}$ jame uravnane $\mathrm{z}$ vodnim nivojem. Različne datacijske metode omogočajo določanje časovnega razvoja jamskih nivojev. Speleogeneza lahko poteka tudi v dveh fazah; v prvi fazi voda ob nizkem gradientu raztopi topen del kamninske matrice (angleško Ghost rock weathering), v drugi fazi pa ob visokem gradientu turbulentni tok mehansko odnese preostali del matrice, pri čemer praviloma nastane labirintni tip jam. Prva faza je lahko povezana $z$ epigeno infiltracijo ali s hipogenim dotokom predvsem na mejnih območjih sedimentnih bazenov. Vertikalna geometrija epigenih jam je pogojena s časovnim okvirom, geološko strukturo, vrsto toka in spremembo erozijske baze. Razvoj mladih (juvenilnih) geometrijskih vzorcev nad nivojem neprepustnih plasti, je povezan

\footnotetext{
${ }^{1}$ University of Nice Sophia-Antipolis, CNRS, IRD, Observatoire de la Cote d'Azur, Geoazur UMR 7329 \& Polytech Nice - Sophia, 930 route des Colles, 06903 Sophia-Antipolis, Nice, France, e-mail: audra@unice.fr

${ }^{2}$ State University of New York, Earth Sciences Department, Oneonta, NY 13820, USA, e-mail: arthur.palmer@oneonta.edu

Received/Prejeto: 26.04 .2015
} 
cave types as (1) juvenile, where they are perched above underlying aquicludes; (2) looping, where recharge varies greatly with time, to produce epiphreatic loops; (3) water-table caves where flow is regulated by a semi-pervious cover; and (4) caves in the equilibrium stage where flow is transmitted without significant flooding. Successive base-level drops caused by valley entrenchment make cave levels, whereas baselevel rise is defined in the frame of the Per ascensum Model of Speleogenesis (PAMS), where deep passages are flooded and drain through vauclusian springs. The PAMS can be active after any type of baselevel rise (transgression, fluvial aggradation, tectonic subsidence) and explains most of the deep phreatic cave systems except for hypogenic.

The term Hypogenic speleogenesis is used to describe cave development by deep upflow independent of adjacent recharge areas. Due to its deep origin, water frequently has a high $\mathrm{CO}_{2}$ $\mathrm{H}_{2} \mathrm{~S}$ concentration and a thermal anomaly, but not systematically. Numerous dissolution processes can be involved in hypogenic speleogenesis, which often include deep-seated acidic sources of $\mathrm{CO}_{2}$ and $\mathrm{H}_{2} \mathrm{~S}$, "hydrothermal" cooling, mixing corrosion, Sulfuric Acid Speleogenesis (SAS), etc. SAS particularly involves the condensation-corrosion processes, resulting in the fast expansion of caves above the water table, i.e. in an atmospheric environment. The hydrogeological setting of hypogenic speleogenesis is based on the Regional Gravity Flow concept, which shows at the basin scales the sites of convergences and upflows where dissolution focuses. Each part of a basin (marginal, internal, deep zone) has specific conditions. The coastal basin is a sub-type. In deformed strata, flow is more complex according to the geological structure. However, upflow and hypogenic speleogenesis concentrate in structural highs (buried anticlines) and zones of major disruption (faults, overthrusts). In disrupted basins, the geothermal gradient "pumps" the meteoric water at depth, making loops of different depths and characteristics. Volcanism and magmatism also produce deep hypogenic loops with "hyperkarst" characteristics due to a combination of deep-seated $\mathrm{CO}_{2}, \mathrm{H}_{2} \mathrm{~S}$, thermalism, and microbial activity. In phreatic conditions, the resulting cave patterns can include geodes, 2-3D caves, and giant ascending shafts. Along the water table, SAS with thermal air convection induces powerful condensation-corrosion and the development of upwardly dendritic caves, isolated chambers, water table sulfuricacid caves. In the vadose zone, "smoking" shafts evolve under the influence of geothermal gradients producing air convectionand condensation-corrosion.

Likely future directions for research will probably involve analytical and modeling methods, especially using isotopes, dating, chemical simulations, and field investigations focused on the relationships between processes and resulting morphologies.

Keywords: Speleogenesis, Epigenic cave, Base level rise, Cave level, Cave pattern, Epiphreatic cave, Flooded karst, Juvenile cave pattern, Looping cave, Mature Through Caves, Per ascensum Model of Speleogenesis, Vauclusian cave, Water-table cave, Paragenesis, Ghost-rock karstification, Hypogenic Cave, Sulfuric Acid Speleogenesis (SAS), Condensation-corrosion, Regional Gravity Flow, hyperkarst, geode caves, 2-3D caves, Giant ascending shafts, Upwardly dendritic caves, Isolated chambers, Water table sulfuric caves, Smoking shafts. s hitrimi tektonskimi dvigi in vrezovanji erozijske baze. V pogojih omejenega odtoka ob spremenljivem napajanju zaradi poplavljanja epifreatične cone nastajajo zavoji v navpični ravnini (angl. loops). Jame vodnega nivoja nastajajo na področjih, kjer je kras pokrit z delno prepustnimi plastmi oz. kjer je speleogeneza uravnotežena z največjimi poplavami. Spreminjanje erozijske baze ob vrezovanju dolin se odraža v jamskih nivojih, medtem ko dviganje erozijske baze diktira razvoj jam od spodaj navzgor (Speleogeneza Per ecensum, PAMS) in nastanek izvirov vokluškega tipa. PAMS se lahko aktivira ob različnih vrstah dviga erozijske baze (zaradi transgresije, rečnega naplavljanja, tektonskega ugrezanja) in pojasnjuje nastanek večine globokih freatičnih jamskih sistemov, razen hipogenih. Izraz hipogena speleogeneza se uporablja za opis razvoja jam zaradi dviganja globokega regionalnega toka. Zaradi izvora iz globin ima voda pogosto visoko koncentracijo $\mathrm{CO}_{2}-\mathrm{H}_{2} \mathrm{~S}$ in temperaturno anomalijo. Pri hipogeni speleogenezi lahko sodelujejo številni procesi raztapljanja, ki so povezani $\mathrm{z}$ globokimi viri $\mathrm{CO}_{2}$ in $\mathrm{H}_{2} \mathrm{~S}$, "hidrotermalnim" ohlajanjem, korozijo mešanice, speleogenezo žveplene kisline (Sulphuric Acid Speleogenesis, SAS), itd. Zlasti SAS vključuje kondenzacijsko-korozijske procese, zaradi česar prihaja do hitrega nastanka jam nad vodno gladino v atmosferskem okolju. Hidrogeološke razmere pri hipogeni speleogenezi so povezane $\mathrm{z}$ regionalnim gravitacijskim tokom, kjer je korozija najmočnejša na območju stekanja in dvigovanja vodnih tokov. Vsak del porečja (obrobni, notranji, globoka cona) ima posebne pogoje. Eden od podtipov je tudi obalno območje. V deformiranih slojih je tok bolj zapleten in strukturno pogojen, pri čemer sta vodni tok in hipogena speleogeneza praviloma vezana na strukturne vrhove (prekrite antiklinale) in na območja večjih strukturnih prekinitev (prelomi, narivi). V prekinjenih bazenih geotermalni gradient "črpa" meteorske vode $\mathrm{v}$ globine, kar povzroča zanke na različnih globinah in $\mathrm{z}$ različnimi značilnostmi. Vulkanizem in magmatizem tudi povzročata globoke hipogene zanke s "hiperkraškimi" značilnostmi, ki nastajajo zaradi kombinacije globokih virov $\mathrm{CO}_{2}, \mathrm{H}_{2} \mathrm{~S}$, termalnih procesov in mikrobiološke aktivnosti. Geometrijski vzorci jam v freatičnih pogojih lahko vključujejo geode, 2-3D jame in navzgor razvijajoča se brezna izjemnih razsežnosti. Nad vodno gladino se zaradi termalne konvekcije in kondenzacijske korozije ob prisotnosti žveplove kisline razvijajo različni geometrijski vzorci jam; dvigajoče se razvejane jame, izolirane dvorane in jame vodnega nivoja nastale $\mathrm{z}$ delovanjem žveplene kisline. V vadozni coni nastajajo tudi "parna« brezna, ko se na območjih termalnih vodonosnikov topel vlažen zrak dviga, ohlaja in kondenzira vzdolž razpok in jih na ta način širi v brezna. V prihodnosti bodo raziskave speleogeneze verjetno temeljile na analitičnih in modelskih pristopih, izotopskih, datacijskih in geokemičnih metodah ter terenskih raziskavah, ki se bodo osredotočala na odnose med procesi in posledično morfologijo.

Ključne besede: speleogeneza, epigena jama, dvig erozijske baze, jamski nivo, geometrijski vzorci jam, epifreatična jama, poplavljen kras, juvenilni geometrijski vzorec, jama $\mathrm{z}$ zavoji, zrele tunelske jame, model speleogeneze Per ascensum, vokluška jama, jama vodnega nivoja, parageneza, Ghost- Rock zakrasevanje, hipogena jama, speleogeneza žveplove kisline, kondenzna korozija, regionalni gravitacijski tok, hiperkras, geodske jame, 2-3D jame, brezna izjemnih razsežnosti, navzgor razvejane jame, izolirane dvorane, žveplene jame na nivoju podtalnice, "parna" brezna. 


\section{INTRODUCTION}

Speleogenesis is the development of well-organized cave systems by water flowing through initial fissures of a soluble rock. Not all fissures will enlarge homogeneously through dissolution. The specificity of cave systems in karst relies on the selective process of fissure enlargement that progressively produces human-size passages, which are well-organized and where flow concentrates with high discharge.

Most cave systems are formed by dissolution of meteoric water infiltrating from the land surface. Aggressiveness toward carbonate rocks is caused mainly by carbon dioxide absorbed from the air and soil. Such caves are called epigenic caves. Beside epigenic caves, a minority of explored cave systems owes its origin to deep upflow, the so-called hypogenic caves. Aggressiveness toward evaporate rocks does not depend on $\mathrm{CO}_{2}$. Such caves were only recently recognized as a widespread phenomenon. They generally contain features and patterns that show evidence for up-flowing of deep water, often with high $\mathrm{CO}_{2}-\mathrm{H}_{2} \mathrm{~S}$ concentration and with a thermal component.

The first conceptual models of cave patterns were based on field experience. They recently evolved thanks to the application of analytical then numerical modeling inputting hydraulics and chemical constraints and also thanks to the extension of field knowledge. Assessing the role of the fractures, of the geological framework, of the recharge and flow regime, modeling allows demonstrating the demonstrating the patterns of flow and the resulting caves in a variety of specified conditions.

One of the main processes controlling the development of epigenic caves is the evolution of the baselevel position, not only while dropping in successive steps as valleys entrench, but also while rising. Flow regime, and especially flooding have an important role in cave development in the epiphreatic zone, which is flooded during high water. Recently, ghost-rock karstification has been recognized as an important process of cave development in certain conditions. In addition to the classical tools used in Earth Sciences such as sedimentology, hydrology, geomorphology, etc., the recent development of dating methods offers new highlights for understanding not only the chronological frame, but also the relationships between cave development stages and the corresponding environmental states. The epigenic cave patterns patterns depend on the combination of the combination of the main parameters (geology, recharge, timing) acting during the development of the cave systems.

Hypogenic caves result from the combination of complex dissolution processes often involving deep-seated acidic sources, sometimes originating from the mantle or from volcanic activity, but also from "normal" rising meteoric water. The importance of regional flow was recently stressed to explain the distribution and characteristics of rising flows at the basin scale. Flow convergence, upflow and outflow loci are responsible for focusing hypogenic speleogenesis, allowing the development of cave systems in specific settings, which are controlled by both topography and hydrogeology. The pattern of hypogenic caves shows a development in phreatic conditions, sometimes at great depth, and also close to the water table. Recent investigations stressed the role of thermal air convections making condensation-corrosion, which can produce caves in short time spans due to extreme acidic conditions, especially in presence of sulfuric acid.

In this paper, we present epigenic and hypogenic speleogenesis. For each, the main controlling parameters and speleogenesis processes are discussed, resulting in specific patterns of cave systems.

\section{EPIGENIC SPELEOGENESIS}

The epigenic caves are formed by water that acquires its solutional capacity from surface conditions. In particular, the ability of water to dissolve carbonate rocks is derived from carbon dioxide absorbed from the atmosphere and especially the soil. Organic acids may contribute to the solutional potential, although their role is not so well understood. Fresh infiltrating water is, of course, capable of dissolving evaporite rocks. On a world-wide basis, epigenic caves probably account for at least $80-90 \%$ of known caves.

While passing through limestone or other type of soluble rock, water from diffuse inputs converges and generally emerges at discrete springs located at the bottom of a valley. The type of flow determines the distribution between vertical zones of karst, as well as the profiles of cave passages (Fig. 1). The vadose zone contains conduits with free-surface streams similar to those on the surface. In the phreatic zone, closed-conduit flow takes place along gentle gradients. In between is the epiphreatic zone, which is flooded during high water and drained during low water, and thus contains both types of flow. As water flows through the initial fissures in a karst massif, it dissolves the surrounding rock and gradually produces well-organized cave systems. Such cave systems are controlled by passive parameters (lithologic and tectonic) and by boundary conditions (type of recharge, topographic gradient, base-level position, etc.). Cave patterns depend mainly on geologic structure, type of recharge, and changes in base level.

The vertical development of epigenic karst is intimately associated with the geomorphic evolution of 


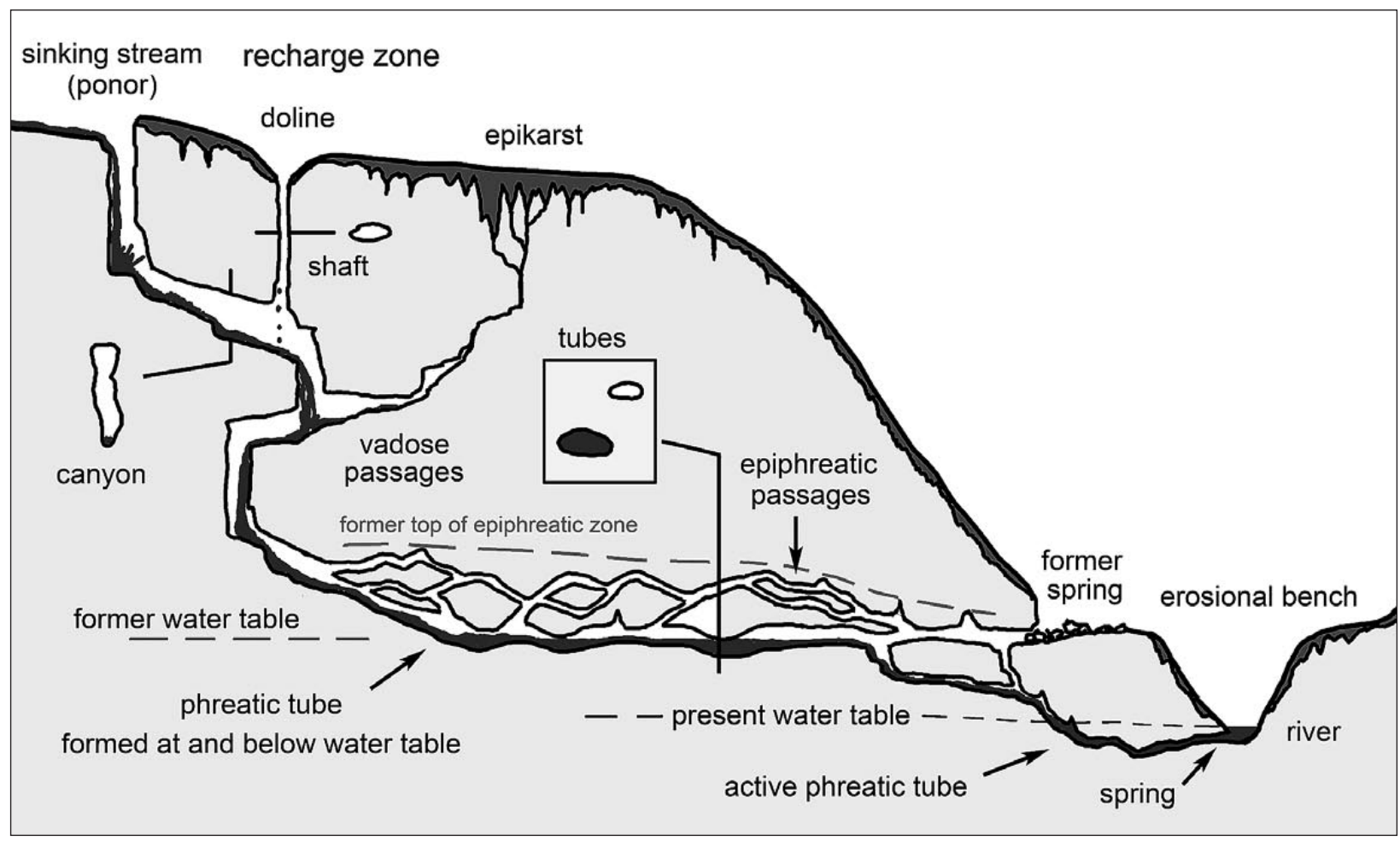

Fig. 1: Idealized cross section through a typical epigenic karst system. Recharge takes place through sinking streams, dolines, and the epikarst to form the tributaries of a branching cave system. Vadose passages (formed above the water table) include shafts and canyons. At the water table, groundwater follows a relatively gentle gradient to springs in nearby valleys. Most phreatic passages are tubular and form at or just below the water table, although many contain vertical loops. During floods (especially in caves fed by rapid runoff), the phreatic passages may be unable to transmit all the incoming water, so complex looping overflow routes form in the epiphreatic zone (zone of water-table fluctuation). Large phreatic passages form when the erosional base level remains at one elevation for a long time, as when erosional benches are formed. As the base level drops and the surface river erodes downward, phreatic passages tend to drain through diversion routes, but the old phreatic passages give evidence of the former base level.

the surrounding landscape. Cave profiles and levels of development reflect the local base level and its changes through time. These cave features tend to be preserved far longer than correlative surface features, which are more susceptible to weathering and erosion. As a result, cave morphology offers abundant clues that are helpful in reconstructing the regional geomorphic history (Ford \& Williams 2007).

\section{Concepts and modeling of cave origin, especially concerning vertical development}

There have been many attempts to construct various models of karst and cave development (Palmer et al. 1999). Conceptual models are based on field observations and the qualitative application of scientific principles. Analytical models rely on quantitative application of the guiding principles, mainly hydraulics and chemical kinetics. Digital models are constructed by finite-difference or finite-element analysis, in which the aquifer is considered to be composed of many small pieces, and the appropriate analytical equations are applied to each by computer software to simulate karst development with time.

\section{Conceptual models}

One of the earliest controversies in karst involved the nature of its groundwater flow. Grund (1903) viewed it as similar to any other kind of groundwater in porous material, with a discrete water table. Katzer (1909) and Martel (1921) disagreed, citing evidence from caves that subsurface water in karst follows interconnected conduits, as though in a plumbing system, with no discrete water table. Today, most hydrologists recognize the merits of both models. Soon afterward there were debates as to where cave development took place relative to the water table. Davis (1930) and Bretz (1942) proposed that caves form deep beneath the water table, when groundwater flowpaths are likely to remain stable for long time periods. Swinnerton (1932) contended that caves are more likely to form where groundwater flow is most vigorous, i.e., at and just below the water table (Fig. 2). This origin can account for the low-gradient profiles of many 


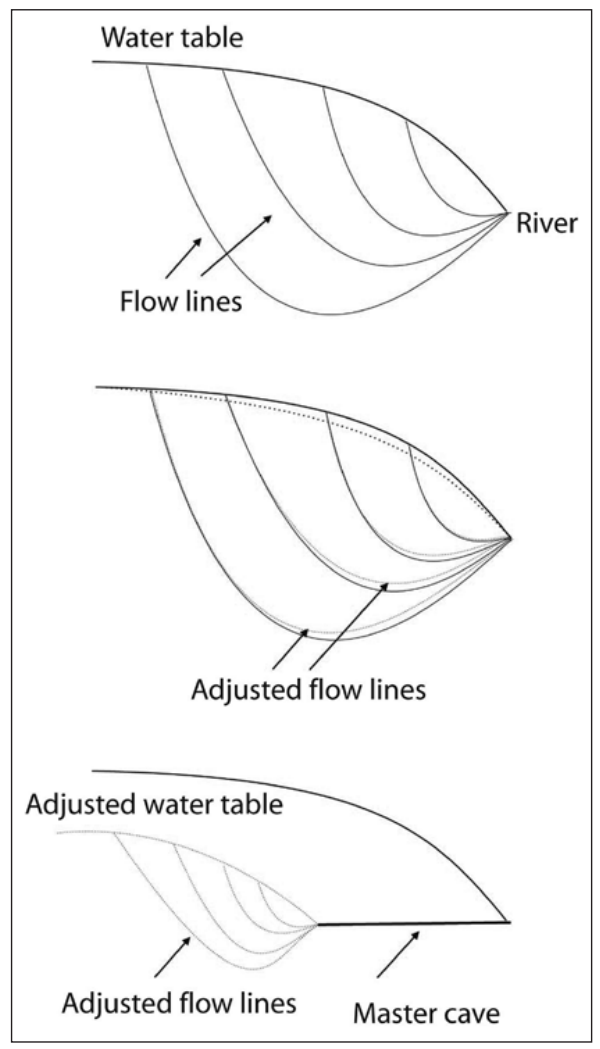

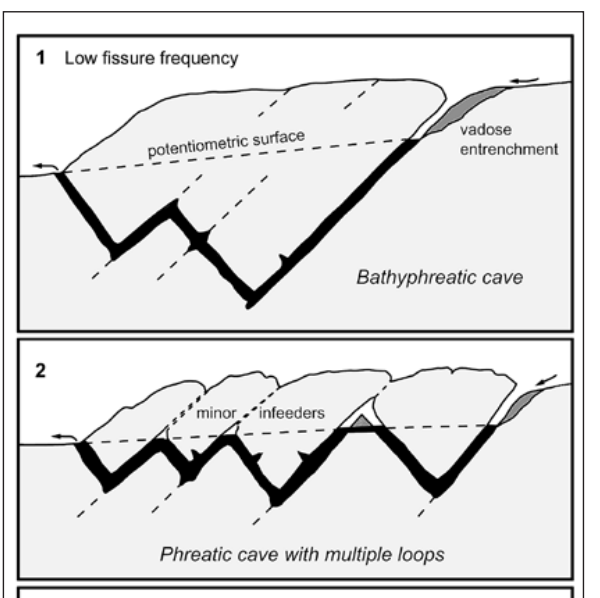
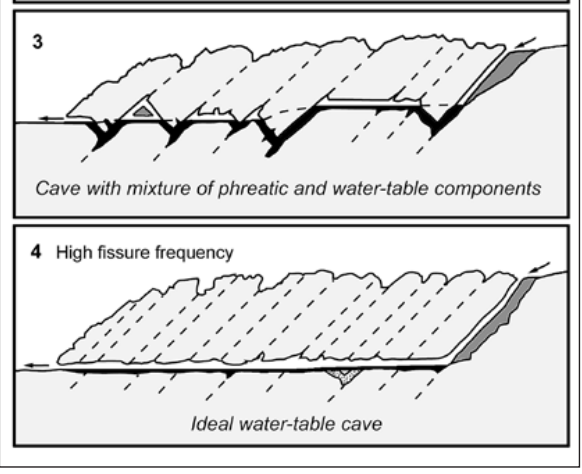

Fig. 2: Left: the water-table cave hypothesis proposed by Swinnerton (1932). Right: The four-state model of Ford and Ewers (1978). Depending on fissure frequency, various types of caves evolve: low fissure frequency (state 1) produces bathyphreatic caves. With increasing fissure frequency the number of phreatic loops increases (states 2 and 3). High fissure frequency (state 4) results in water-table caves. Extremely low or extremely high fissure frequency does not allow evolution of caves (state 0 and 5, not shown here). The four states do not necessarily follow one another (after Ford 1999). phreatic passages. He considered the zone of water-table fluctuation to be most favorable for cave origin.

Ford (1971), and Ford and Ewers (1978) proposed a model based on groundwater flow fields and the spatial density of fissures (i.e., fractures and partings). They envisioned a four-state model with the following sequence (Fig. 2): (1) Where fissure frequency is low, only a few fissures are available to transmit enough water to form caves. In this case, there is a tendency for only a few phreatic loops to form - or perhaps just a single loop. (2) Where fissure frequency is greater, multiple loops develop that are shallower than in case 1. (3) Where fissures are still more numerous, both phreatic loops and watertable segments are able to develop. (4) Where fissure frequency is so great that phreatic loops cannot form at all, cave passages develop almost entirely along the water table. There is a tendency for these states to follow one another with time, as fissures become more numerous with time, owing to pressure release. In this situation, caves may evolve from deep systems with few phreatic loops to shallow systems dominated with water-table passages where fissures are numerous. For an illuminating discussion on the topic, both pro and con, see Ford (2014).

Worthington $(2004,2005)$ questioned the validity of the Ford-Ewers model by noting the development of sub-horizontal caves as much as $100 \mathrm{~m}$ below the water table. He also showed statistically that depth of phreatic cave development is proportional to the overall length of flow paths and angle of the stratal dip.

\section{Analytical models}

Palmer (1991) combined hydraulics with chemical kinetics to explain cave patterns: (1) Early cave enlargement rates depend on the ratio of discharge to flow length $(\mathrm{Q} / \mathrm{L})$. Differences in this ratio account for the varied growth rate among the competing flow paths. (2) Along any path, enlargement rates increase with discharge, but only up to a certain limit. From then on, greater discharge affects the enlargement rate only slightly. (3) Only a few paths reach cave size, while others stagnate with little further growth. Branchwork caves with relatively few passages are formed. (4) Maze caves form where Q/L is large along many alternate routes. Epigenic mazes form by recharge through adjacent permeable but insoluble rock (small $L$ and/or uniform $Q$ ), or where floodwaters with large discharge are ponded behind constrictions so that water is injected under pressure into all fissures in the adjacent bedrock.

\section{Digital models (computer simulation)}

Using finite-difference modeling, Dreybrodt (1990, 1996) and Palmer (1991) independently determined the breakthrough time $\left(t_{\mathrm{b}}\right)$ needed for a fissure to reach its maximum growth rate. They both showed that $t_{\mathrm{b}}$ decreases with 
the cube of the initial fissure width, and with roughly the $4 / 3$ power of the hydraulic gradient and the $-4 / 3$ power of the flow distance. Thus the most favorable paths for cave development are (by far) the widest initial openings, and (less importantly) the steepest hydraulic gradients and shortest flow distances. Breakthrough time also decreases at higher $\mathrm{CO}_{2}$ partial pressures and lower water temperatures (Palmer 1991). Breakthrough times on the order of $10^{5}$ yrs are typical in epigenic caves. Gabrovšek (2000) showed that mixing of waters of varied $\mathrm{CO}_{2}$ content can decrease the breakthrough time, but that large differences in $\mathrm{CO}_{2}$ concentration are necessary.

Dreybrodt and others (2005) summarized the previous 15 years of karst modeling. Among their many conclusions are: (1) The main solution conduits tend to concentrate at or near the water table (Fig. 3). The presence of relatively wide fractures in the initial system can lead to phreatic loops, but only if they develop prior to those at the water table. (2) Depth of penetration of solution conduits below the water table is affected very little by aquifer thickness, because the water at depth is mainly saturated with dissolved carbonate minerals.

These last advances established that main drains develop along the water table or at shallow depth, with possible loops of various depths if prominent fractures are present. Within this general context, passive parameters (geology) and boundary conditions (discharge, base-level position ...) will play a key role to determine the cave pattern.

\section{Some of the most important processes acting in epigenic speleogenesis Complex relationships between cave levels and base level}

As a surface stream erodes its valley deeper, karst springs that emerge in the valley tend to shift to progressively lower elevations. The cave passages that feed the springs also migrate downward, following the drop in the water table. Therefore, in most caves the highest passages are the oldest and the lowest are younger. A cave level consists of one or more passages that are confined to a narrow vertical range. This term should apply only to passages that correlate with present or former base levels. Where structural or stratigraphic features are responsible for a narrow vertical range, the term tier or story is more appropriate.

If a stream valley deepens rapidly, cave streams tend to shift to lower routes so frequently that their passages do not remain active long enough to reach a large size. When there is a pause or slowing of entrenchment, the valley bottom broadens into a floodplain, and cave passages at that level have time to acquire large cross sections. These passages constitute a true cave level. The level may be represented by a single passage, but the

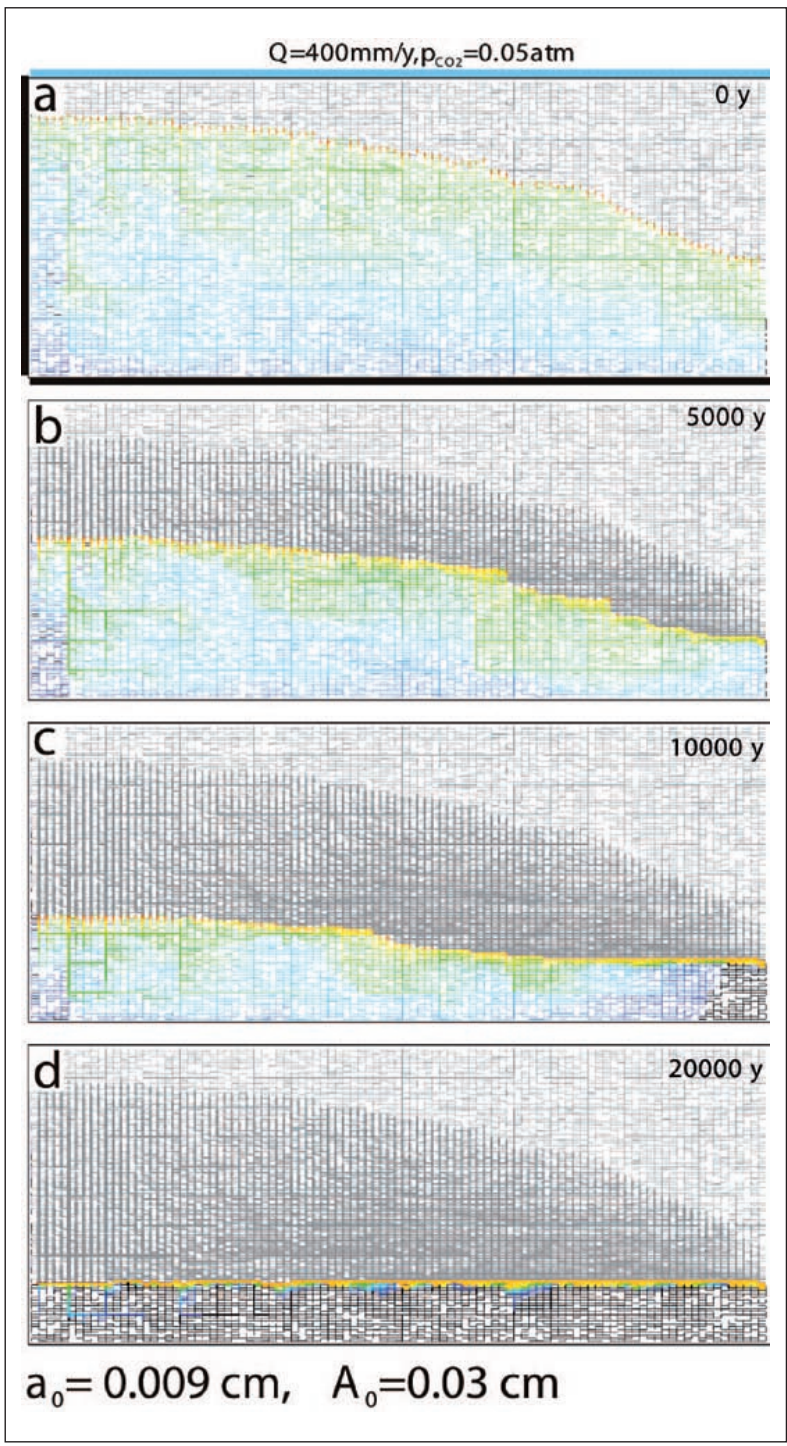

Fig. 3: Simulation of vertical profiles of cave development (Dreybrodt et al. 2005). Dissolutional widening is most active in a restricted region below the water table, where maximum flow occurs. Gradually, by headward erosion, the water table becomes almost horizontal, whereas diffuse flow in the phreatic zone simultaneously decreases. In this network, the initial aperture width $a_{0}=0.009 \mathrm{~cm}$ and the dissolved solute entering the system is at $90 \%$ saturation. The blue line shows a surface recharge of $400 \mathrm{~mm} / \mathrm{y}$. There is no flow across the left and bottom boundaries; the river at base level provides a constant-head boundary (right). Flow rate is shown in color (increasing from blue to red); fissure aperture is shown in grey. Successive runs at $t=0,5,10$, and $20 \mathrm{ky}$. Eventually a low-gradient water table concentrates most of the flow toward the spring at the base level.

interpretation is greatly supported if several passages in the same cave, or in adjacent caves, all have similar elevations. It is not the average elevation of a passage that is important, but instead the elevation of the present (or former) vadose-phreatic transition. 
Fluvial base levels change irregularly, often with periods of valley filling, according to changes in sea level, climate, and rates of uplift of the land. Glacial advances and retreats have a large effect, as do adjustments in the pattern of surface rivers. Some cave levels correlate with river terraces (Davies 1960; Droppa 1966; White \& White 2001), which suggests cave origin at or just below the water table. But in recent decades a growing number of researchers have found that the relationship of cave passages to the water table is more complex.

The presence of a vadose passage shows that, while it was forming, the floor of its outlet valley must have been at a lower elevation than the passage. Vadose passages cannot qualify as true cave levels because they form along the descending paths of gravitational water, which are independent of one another. A poorly soluble bed may cause perching of vadose passages at a common elevation, but this is a structural phenomenon that does not relate to the position of base level.

A valid interpretation of cave levels, in the geomorphic sense, requires the recognition of vadose-phreatic transition zones (see Fig. 1). The hydraulic gradient in a water-filled cave passage is so low, except during major floods, that these transition zones are only slightly higher in elevation than the local spring. Although caves enlarge fastest during floods, floodwater dissolution extends over a wide vertical range, with no single dominant elevation, and this process can blur the distinction between cave levels.

\section{Epiphreatic cave development and significance of vadose-phreatic transition}

The depths of phreatic loops do not invariably diminish in progressively lower passage levels. In Mammoth Cave, Kentucky, USA, the deepest known phreatic loop (21 m) is in the lowest and most recent of the major passages (Palmer 1987). This is the result of thick-bedded, prominently jointed strata at that elevation.

Many epiphreatic passages, which form above the low-flow water table under hydraulic pressure, also have irregular profiles with high-amplitude loops. Audra (1994) emphasized the influence of the epiphreatic (floodwater) zone for speleogenesis of passages of apparent phreatic origin, and Häuselmann et al. (2003) subsequently refined the model, explaining speleogenesis of Bärenschacht (Switzerland) on the basis of floodwater fluctuations. Water chemistry measurements as well as direct observations in caves have shown that floodwaters are much more corrosive and erosive than low waters (Palmer 2007), and that, for instance, scallops size reveals the high floodwater flow velocity (Lauritzen et al. 1983). We thus can ascertain that floodwater effects are very important in speleogenesis and mainly results in looping tubes developing in the epiphreatic zone (see below "Looping caves"). In such caves, high-level passages with large vertical loops are not necessarily the oldest.

\section{The widespread effect of rising base level: phreatic lift and paragenesis}

Rises in base level may disrupt the tendency for passages in a cave to become progressively younger with depth. Some possible causes include rising sea level, decreasing stream flow, and glacial depression of the Earth's. Most of these effects are relatively short-lived, on the order of thousands or tens of thousands of years, but some have endured for millions of years. Even brief episodes can have long-lasting effects.

A base-level rise is usually accompanied by sediment filling in valleys to that new level. In most cases, the sediment is deposited by the river itself (alluviation), although glacial or marine deposits may also be responsible. Cave passages below this level become flooded. They may eventually become sediment-filled, especially if their flow is feeble or is diverted into formerly abandoned passages at a higher level.

Paragenesis is the upward dissolution of the ceiling in a water-filled cave passage because of sediment accumulation on the underlying floor (Renault 1970; Farrant 2004; Farrant \& Smart 2011; Pasini 2009; Lauritzen \& Lauritsen 1995). The sediment shields the floor from aggressive water, leaving only the upper surfaces of the passage exposed to dissolution (Fig. 4). As the ceiling dissolves upward, more sediment accumulates on the floor to maintain the

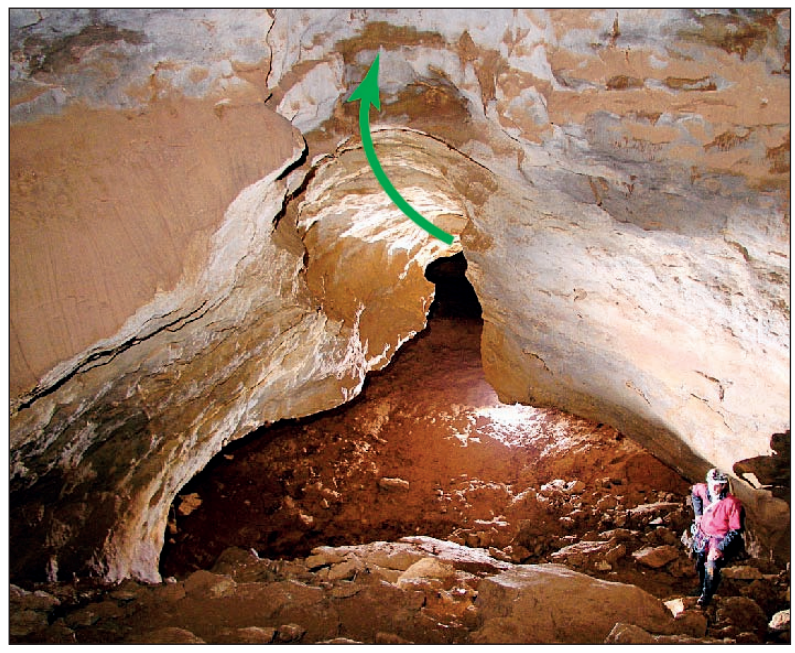

Fig. 4: Paragenetic ceiling channel, Camelié Aven, France (Photo: J.-Y. Bigot). It developed by water flowing on top of a sediment filling, here later removed by erosion. The presence of generalized sediment filling associated to wall and ceiling channel make possible to distinguish such paragenetic feature from rising half tubes and condensation-corrosion channels, which are generally devoid of any sediment. 
equilibrium among erosion, deposition, and water velocity. Upward migration stops when the tube reaches the water table. Later, as the water table drops, the passage is either abandoned or its sediment is excavated by the cave stream. Paragenesis is often caused by floodwaters, which are highly aggressive, sediment-laden, and abrasive.

The paragenesis process was previously often considered only local in scale, resulting in passage collapse or various kinds of discrete plugging. Recent studies (Farrant \& Smart 2011; Mocochain et al. 2009) found that paragenesis is generally widespread and may result from base-level rise that is either regional (e.g., from glaciation) or widespread (e.g., from transgression).

The influx of sediments by sinking streams contributes to paragenesis by plugging the lower parts of the loops resulting in regularized long profiles. Consequently, sediment influx and paragenesis also contribute to the evolution toward the watertable pattern.

\section{The development of dating methods}

Because the vertical arrangement of an epigenic cave system has such a close relation to the regional geomorphic history, dating of cave passages can be of great benefit to reconstructing and interpreting that history. The main difficulty is that the caves themselves are voids that cannot be dated directly. However, dating of deposits in the caves can show the minimum ages of cave origin. Chemical deposits (speleothems) are easiest to date, but their ages generally have little direct bearing on cave origin. Most useful are dates on detrital sediment, because the sediment was presumably carried in by the same water that participated in the last phase of passage enlargement.

Paleomagnetic measurements of cave sediments have been successfully used for geomorphic interpretations. However, the method relies on determining the positions of polarity reversals, and continuity of the sediment sequence is required to assure that there are no time gaps (Schmidt 1982; Sasowsky 2005). Measurement of the cosmogenic radionuclides ${ }^{26} \mathrm{Al}$ and ${ }^{10} \mathrm{Be}$ in quartz sediment is most appropriate, because it gives a continuous range of numerical dates, with no gaps; and its useful range extends to about 5 million years, which is sufficient to cover the entire genetic history of most caves (Granger \& Fabel 2005). In Mammoth Cave, Kentucky, USA, dates of passages at various levels have been obtained from ${ }^{26} \mathrm{Al} /{ }^{10} \mathrm{Be}$ ratios in detrital sediment from the last $3.5 \mathrm{Ma}$ (Granger et al. 2001; Audra \& Palmer 2013). Evolution of the cave has been controlled by the regional Ohio River system, which in turn has been affected by continental glaciation. Major alterations of the river pattern resulted in episodes of incision and aggradation that controlled the successive stages of cave development and sedimentation. Using
K-Ar dating of illite originating from hydrothermal neoformation, Osborne et al. (2006) shown that part of Jenolan Caves (Australia), formed in the Carboniferous Period (342 to $335 \mathrm{Ma}$ ). This is by far the oldest absolute age of a cave deposit found in a currently open cave. Similarly, Ar-Ar dating of K-bearing neoformation minerals such as jarosite and alunite were successfully used to date sulfuricacid caves millions of years old sulfuric caves (see section Special focus on sulfuric acid speleogenesis (SAS) and condensation-corrosion).

\section{Ghost-rock karstification}

Ghost-rock karstification is a process that was first identified in Belgium (Vergari 1997), then Italy, Switzerland and France and which is in fact present in many areas (Dubois et al. 2004, and references herein). It differs from the traditional single-stage process of karst development that proceeds in a total removal of rock along initial fissures. The first stage of ghost-rock karstification is characterised by chemical dissolution and removal of the most soluble crystals of a grain-heterogeneous rock, i.e. the calcite grains in impure limestone, or the smallest micritic crystals vs. sparite in pure limestone. It requires low hydrodynamic energy and creates a ghost-rock feature, mimicking the fracture pattern filled with the residual weathering products, the ghost. It has a highly porous texture where initial rock features are preserved, such a calcite dikes and fossils. The ghost-rock karstification can develop at considerable depth below base level, providing some fresh flow is able to maintain the aggressivity and to transport the solutes during a long-lasting time, several orders of magnitude longer than in the classical epigenic speleogenesis. The second stage is characterised by mechanical erosion of the remaining undissolved particles of the ghost. It requires high hydrodynamic energy, i.e. a base level drop after uplifting and/or valley incision, and it is only then that open galleries are created, mostly by mechanical erosion and transport of the fine grains. It results in cave systems adjusted to the fracture pattern, such as mazes. However, branching patterns are also present after ghost-rock karstification, since flow driven by gravity may select only some of the ghost directions corresponding to the flow lines. Passage morphologies are very similar to those of phreatic passages, with round profiles, bridges, dead ends, etc.

The ghost-rock karstification process has been poorly recognized up to now. Firstly, because the second phase of mechanical removing of the ghost erases the initial evidence, which may remain only in dead ends and in areas protected from turbulent flow (Fig. 5), and secondly, because the resulting morphologies (maze pattern with phreatic-like passages) were often misinterpreted as phreatic in origin. 

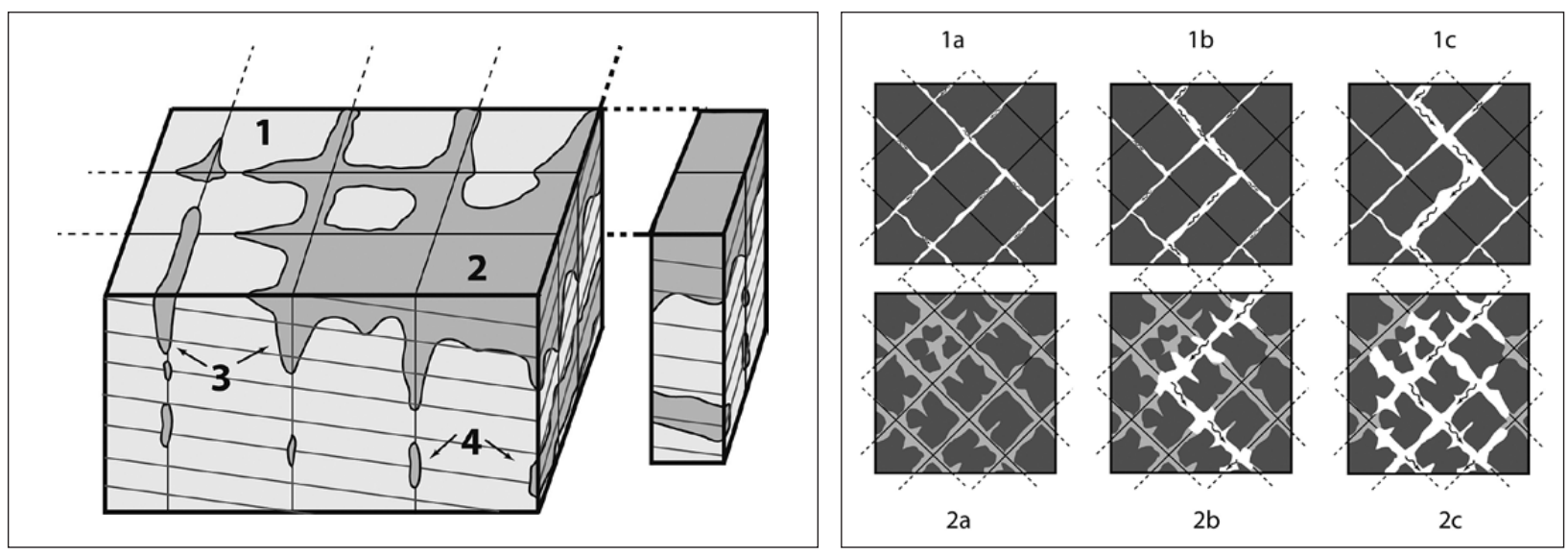

Fig. 5: Left: different types of ghost rocks. The unweathered rock (1) is cut by numerous discontinuities (joints and bedding planes), which are partly used by the ghost-rock karstification. The ghost-rock occurs as weathered masses (2), as pockets and corridors (3), and as pseudo-endokarst with a hard rock ceiling, which prefigures the future cave passages (4). Upper right (1a, b, c): "normal" karst evolution by complete removing of rock and branching pattern development. Lower right $(2 a, b, c)$ : ghost-rock karstification. In the early stage of low-gradient, slow flow produces the residual matrix but cannot export it (A). After a base-level drop resulting in a steep hydraulic head, turbulent flow appears and exports the fine particles by headward erosion (B). Gradually, the fracture frame is revealed and a maze appears in lieu of the initial ghost (C). The remote parts, away from the turbulent flow, remain filled with the ghost (Bruxelles et al. 2009).

Originally, the rock-ghost karstification has been attributed to epigenic processes, i.e. a kind of weathering slowly developing downward from the surface (Quinif 2010, and references therein). Such an origin is evident in many places, and it now appears that entire regions of ghost-rock karstification have been clearly affected by hypogenic flows (Bruxelles \& Wienin 2009). In France, most of the marginal areas of basins at the contact of cratons were subject to hypogenic processes by deep upflow expelled from the basin central deep zones (peripheries of Central Massif, Vosges Mountain...). Such low regions are now characterized by the association of mineralized sulfide ores and caves of predominantly maze pattern. These caves result from the removal of the ghost rock following the rearrangement of the karst drainage after the recent uplifts. If the process is now well understood at the scale of the ghost (Quinif 2010) a more general conceptual model at the regional scale will probably soon integrate the ghost-rock karstification with both epigenic and hypogenic processes.

\section{GUIDANCE ON VERTICAL CAVE PATTERNS}

The geological structure, the type of flow, and the steps of base-level changes play a key role in organizing the vertical pattern of epigenic caves. Thus, vertical cave pattern is mainly controlled by time, by the position of the aquifer (perched vs. dammed), by recharge type (regular vs. irregular), and by base-levels changes (lowering vs. rising) (Audra 2001; Palmer \& Audra 2004; Audra \& Palmer 2013).
The juvenile pattern: a time-dependent pattern The juvenile pattern prevails when soluble rocks are first exposed by uplift and removal of any impermeable cover. During cave inception, the mixing of saturated groundwater with aggressive water forms points of recharge that allows corrosion to take place along a steep water table. Because of sparse fracturing, the water table can be steep and located high above fluvial base level (Fig. 6). Initial phreatic paths are later entrenched as the water table drops and the flow becomes vadose. Vadose

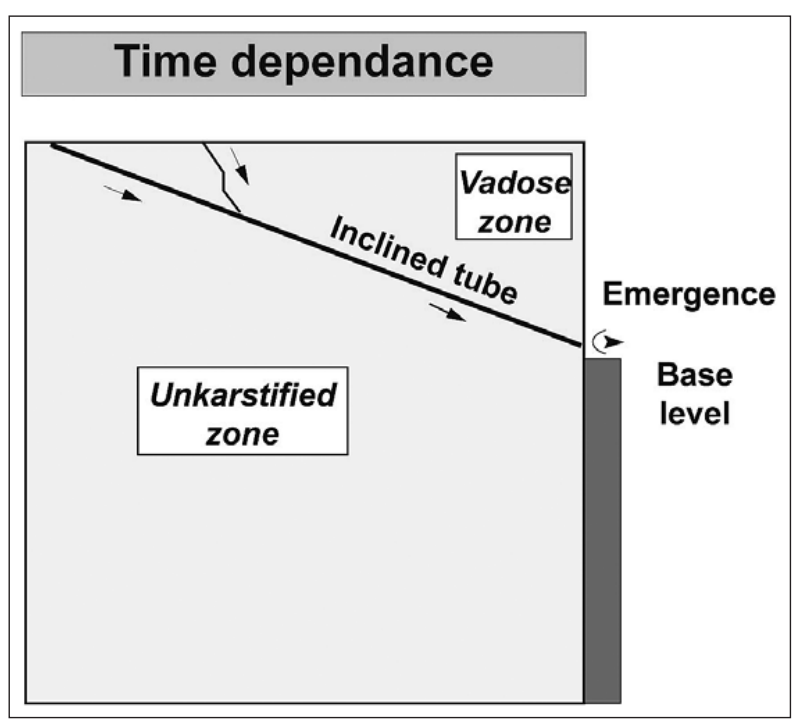

Fig. 6: Juvenile pattern: in the first stage of karstification, when high gradient is present, a cave system develops a steep profile with the greatest hydraulic gradient. 
enlargement, as shafts, meanders, and canyons, often obscures the initial phreatic paths, which are sometimes preserved as ceiling channels. The juvenile pattern often corresponds to the initial phase for most vertical cave passages (shafts). These are common in young, rapidly developing karsts (Fig. 7) such as:

- in karst subjected to intense dissolution, after rapid uplift and great rainfall: Nakanai Mountains, Papua New Guinea;

- in evaporite rocks where sinkholes deliver water to through-caves directly connected to resurgences: Gébroulaz in gypsum, France; caves of the Mount Sedom in halite, Israel (Frumkin 1998);

- in limestone exposed for the first time by glacial erosion, which has removed the impermeable cover, Grand Marchet, France.

\section{Perched caves and their geological control}

Where the aquifer is perched above base level on an underlying aquiclude, there is no significant phreatic cave development (Fig. 8). Shafts and canyons converge to form conduits at the aquiclude top and feed springs along hillslopes. Major springs drain into the heads of pocket valleys. Mechanical erosion, aided by detrital sediment, quickly enlarges the main routes by entrenching the underlying aquiclude, especially if it is soft material such as marl. Such mechanical erosion of the impervious basement is responsible for the development of one the second-largest underground chamber of the planet (Sarawak Chamber in Gunung Mulu). Large galleries develop by collapse of the limestone ceiling and may fill with boulders. Base-level lowering promotes headward retreat of the spring but does not noticeably affect the cave pattern.

\section{Dammed karst and its control by base-level position}

In "dammed karst" the karst aquifer extends below the spring outlet, which is determined by a fluvial or structural base level. In turn, the spring position determines the water-table elevation inside the karst. The main drain becomes established at the water table, at the end of the

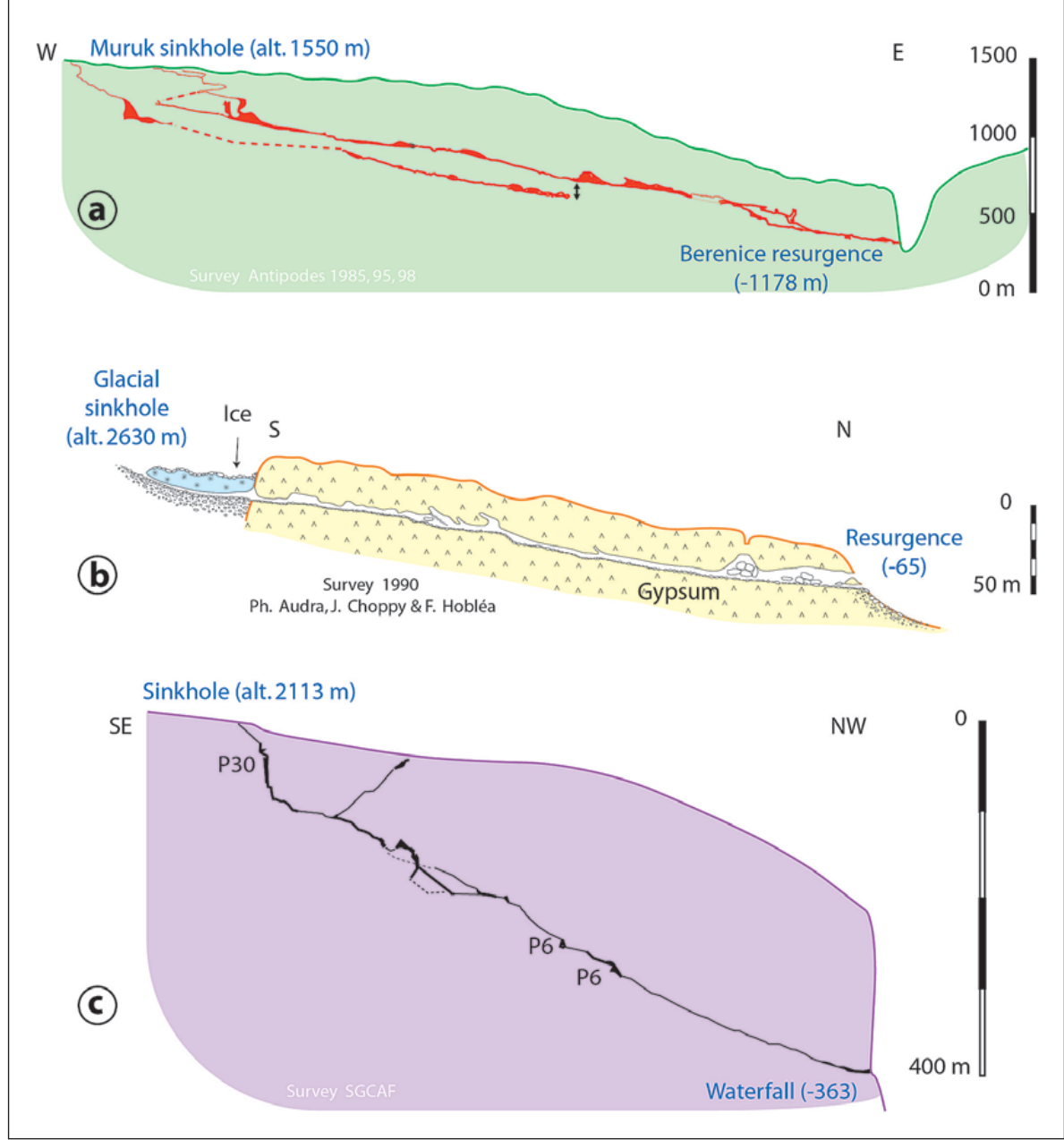

Fig. 7: Examples of juvenile cave patterns, displaying a straight long profile, where a sinkhole feeds through-caves directly connected to the resurgence. Flow is vadose, and no significant phreatic zone is present (profile with no vertical exaggeration).

1. Muruk System (Nakanai Mountains, Papua New Guinea). Intense rainfall $(>10 \mathrm{~m} / \mathrm{y})$ generates surface runoff on clay covers, which feeds numerous sinkholes. Huge cave systems develop into recently uplifted soft Miocene limestone. High-discharge rivers flow through large galleries and canyons (Audra et al. 2011).

2. Gebroulaz Cave (Vanoise, France). Glacial meltwater sinks rapidly into a gypsum body and flows through it in a $350 \mathrm{~m}$-long gallery with a gentle gradient (Audra \& Hobléa 1996).

3. Grand Marchet Sinkhole (Vanoise, France). A small stream sinks into a marble body. The passages develop along metamorphic schistosity and lithologic contacts (Audra \& Palmer 2013). 


\section{Geological constraint}

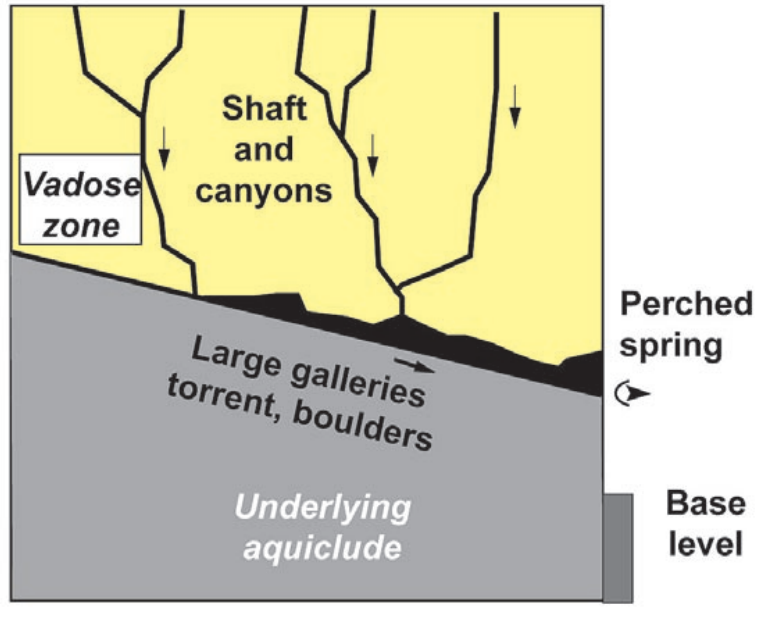

Fig. 8: Perched caves: a vadose system develops at the contact of the underlying aquiclude. The mechanical erosion of soft underlying material enlarges galleries, sometimes forming huge chambers. Collapses of the limestone ceiling have partly filled the gallery with boulders.

passage with the lowest elevation. Major passages either follow the water table or contain shallow phreatic loops.

\section{Looping caves in the epiphreatic zone formed by} irregular recharge

During high flow, water rises in phreatic lift tubes and emerges at overflow springs, e.g., Castleguard Cave,

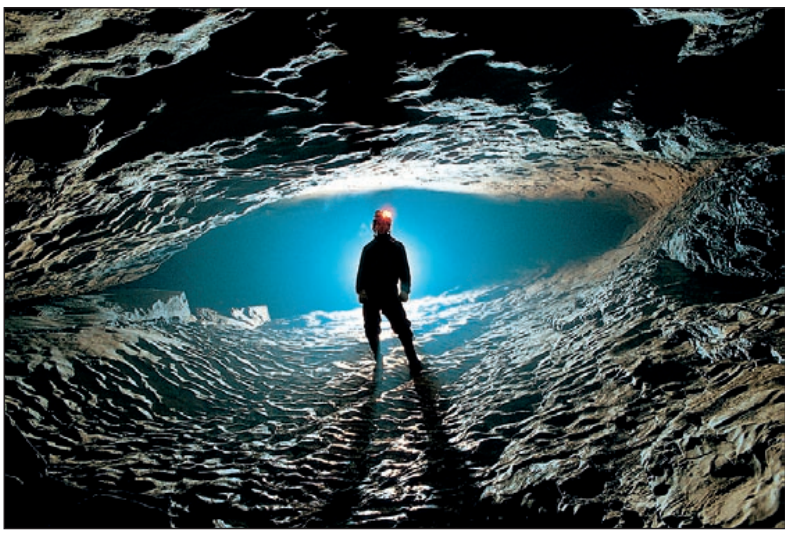

Fig. 10: The Hölloch System (Alps, Switzerland) is a maze of active and ancient epiphreatic passages. Such tubes flood over more than $200 \mathrm{~m}$ depth during high water (Photo: courtesy U. Widmer).

Canada (Ford 1983). During low flow the water emerges at springs at lower elevations. (Fig. 9). In the Siebenhengste Cave System (Switzerland), Häuselmann (2002) studied the shifting from gravitational downcutting forming canyons to tubular passages formed by closed-conduit flow (Fig. 10, 11). This study allows reconstruction of the vadose-phreatic transition zones corresponding to former water-table positions. He demonstrated that these transition elevations decrease toward the springs and record the top of the epiphreatic zone, i.e. the highest position of the water table. Consequently, this study shows that high-amplitude looping passages form in the epiphreatic zone and are enlarged by aggressive high flows. Passage amplitudes can exceed $200 \mathrm{~m}$.

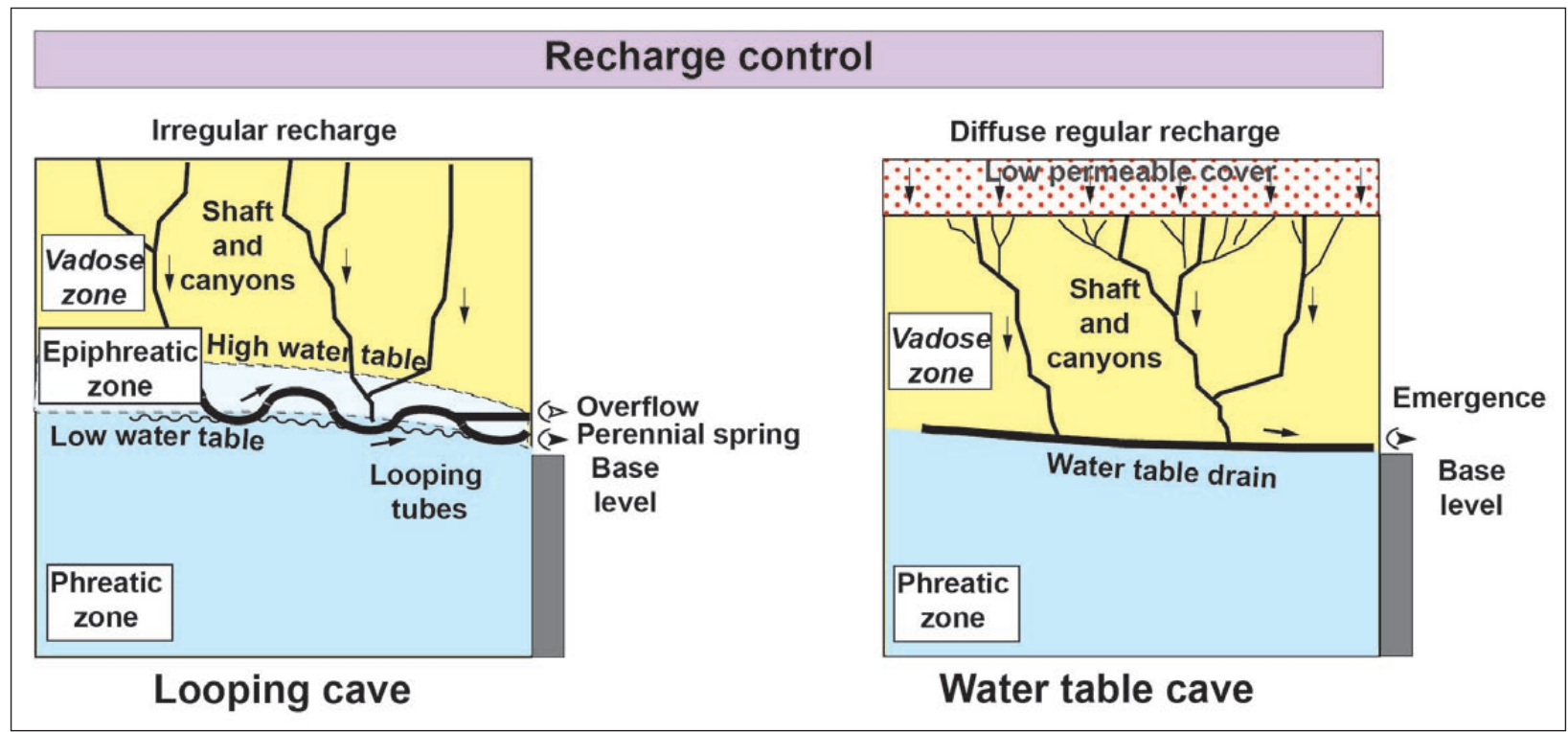

Fig. 9: Left - An epiphreatic cave: irregular recharge causes backflooding; drains develop throughout the epiphreatic zone, with looping profiles resulting from the influence of structural openings. Right - A water-table cave: recharge through a poorly permeable cover is diffuse and regular, so the water-table level remains stable with time and the drain develops at the water table. 


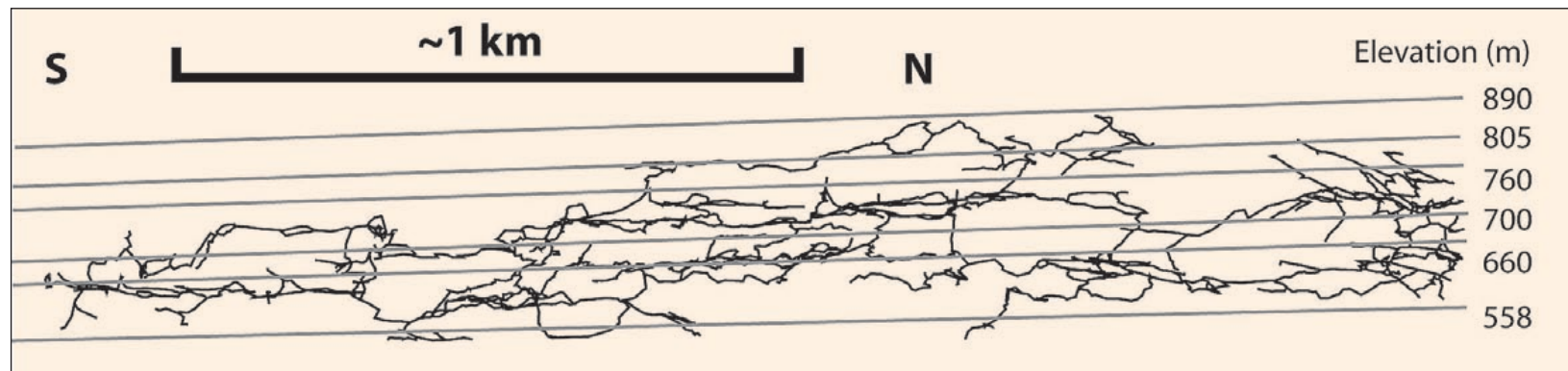

Fig. 11: Cross section of the southern part of Bärenschacht, with indications of the speleogenetic phases (after Häuselmann et al. 2003; Häuselmann \& Granger 2005). Loops with amplitudes as high as $150 \mathrm{~m}$ are visible, and mazes are due to flooding and draining processes. The successive lowering of base level produces several speleogenetic levels. Passages are braided because the amplitude of epiphreatic loops is higher than the altitude difference between each speleogenetic phase. It results in a complex maze connecting active and fossil passages, altogether developing several dozen kilometers of passages.

This observation shows that cave levels effectively record the base-level positions, but the cave-level altitudes can be noticeably above that of the corresponding base level. In addition, the amplitude of the loops depends on the vertical amplitude of the epiphreatic zone, and thus on the height and suddenness of flooding. Consequently, epiphreatic speleogenesis is due to an irregular discharge, either from storms or from glacial or snow melt), or as the result of concentrated surface runoff into dolines (Audra 1994).

Water-table caves: regulated recharge or low head losses in mature through caves

When a karst is overlain by a thick semi-permeable cover that acts as a filter, there is little fluctuation in recharge. The regulated seepage induces the regularization of the transfer (Fig. 9). In contrast to bare karst, flooding and the development of an epiphreatic zone are very limited. The main drains concentrate at the water table where the water flow is continuous. Cave systems display low-gradient passages with extensive pools.

Similar long profiles are characteristic of throughcaves fed by extensive impermeable catchment areas providing coarse sediments and where base level re-

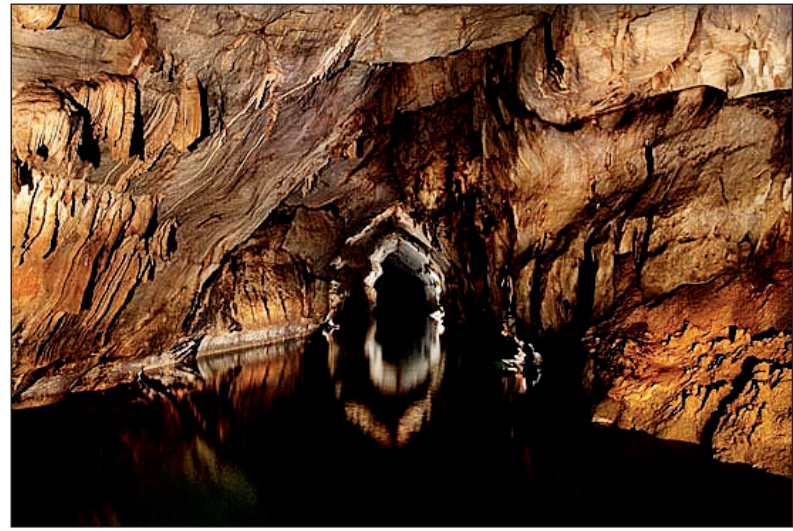

Fig. 12: Saint Paul Cave (Palawan Island, Philippines) is a 24 $\mathrm{km}$-long cave system. The resurgence opens along the shoreline and the cave extends inland several kilometers. The main drain consists of a large water-table conduit in which the influence of tides is felt as much as $6 \mathrm{~km}$ inside the cave (Photo: courtesy E. Procopio).

mains stable over extensive periods. When such caves reach the equilibrium state, their passage size is large enough to allow the transfer of all stages of flow, including seasonal peaks. Such through-caves are frequent on stable platforms such as in Brazil and in monsoonal

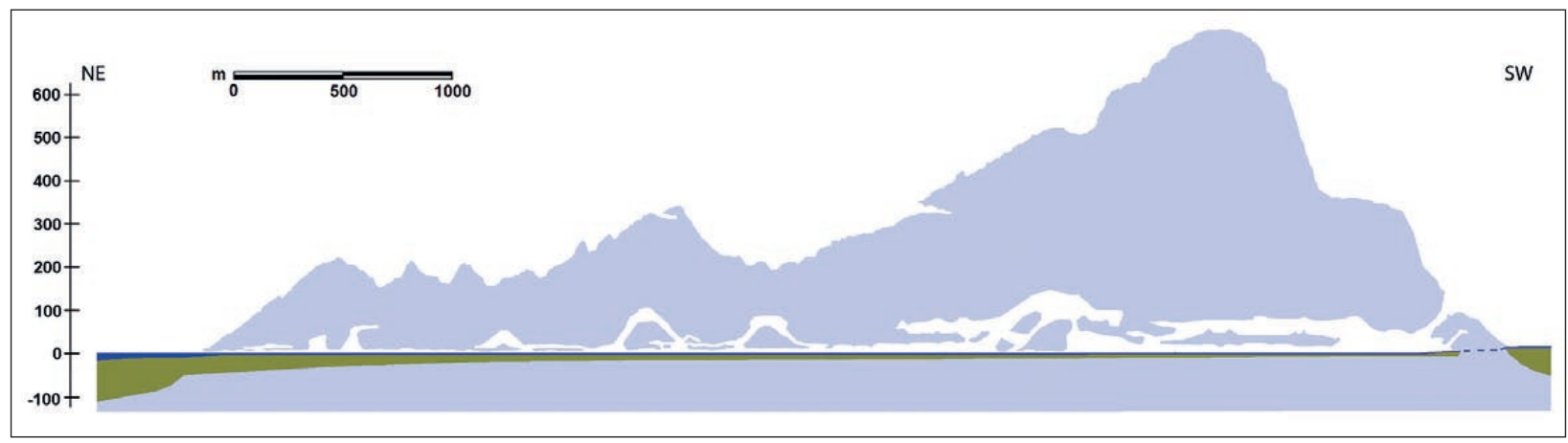

Fig. 13: Profile of Saint Paul Cave (Palawan Island, Philippines). The cave drains a polje at low altitude through a $6 \mathrm{~km}$ long passage along the water table and discharges to the sea (Piccini \& Iandelli 2011). 


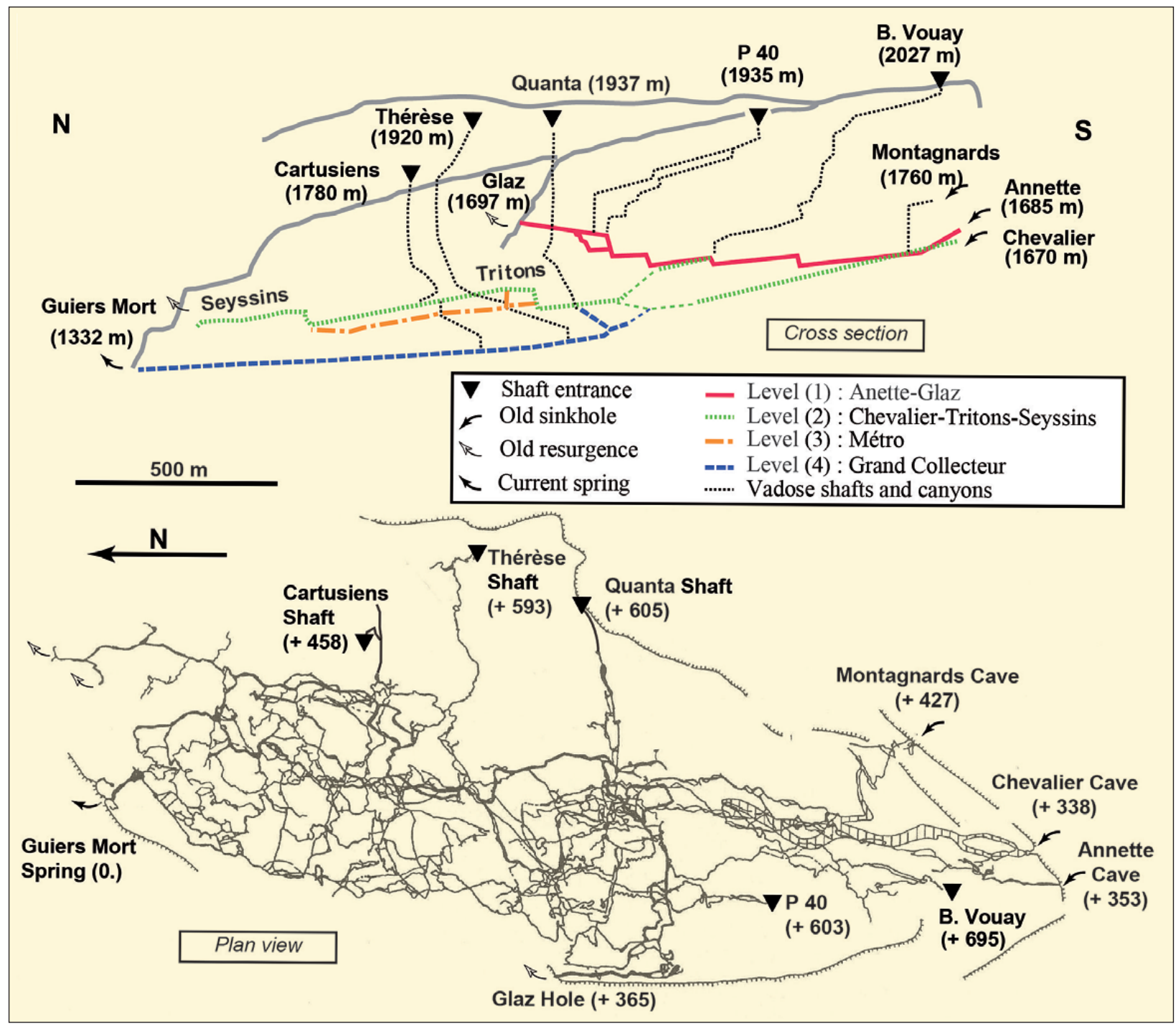

Fig. 14: The Dent de Crolles system, France, contains $57 \mathrm{~km}$ of passages over almost $700 \mathrm{~m}$ of depth, below a surface less than $1.5 \mathrm{~km} \mathrm{~m}^{2}$ in area. The cave consists of vadose shafts and canyons originating from the plateau surface, and which connect to four distinct semihorizontal levels. The three highest levels are perched fossil galleries within the limestone mass; the lowest one, at the contact with the underlying aquiclude, is active.

southeast Asia (Laos, Vietnam, China, Thailand, Philippines; Figs. 12, 13).

\section{Development of cave levels resulting from base-level lowering}

In dammed settings the inner organization of karst drainage strongly depends on the base-level position. Any change in base level affects the position of the water table itself and induces a reorganization of the drainage. If fluvial base-level drops stepwise, successively lower phreatic passages develop (Fig. 15). Pauses in base-level lowering produce cave levels that correlate with river terraces, e.g., at Mammoth Cave, USA (Granger et al. 2001). Vadose shafts and canyons extend the vadose zone down to the new water table. Former conduits and springs are abandoned and partly filled with floodwater sediments and speleothems. Perched in the vadose zone, old phreatic conduits are cut by new "invasion" shafts and canyons that feed active conduits.

Most of the large cave systems in the world correspond to this type of system with integrated cave levels recording successive base level lowering, respectively: Mammoth Cave, USA; Siebenhengeste, Switzerland; Clearwater Cave, Malaysia; Dent de Crolles, France (Fig. 14). 


\section{Base level change control}

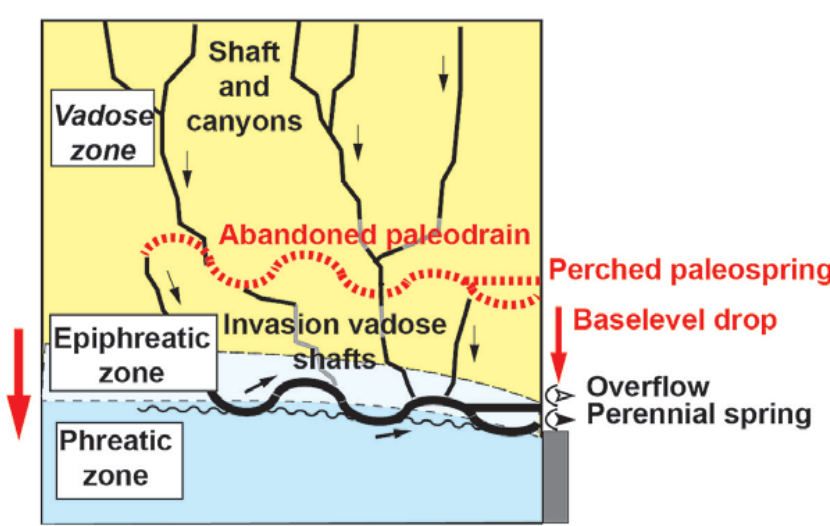

Cave levels

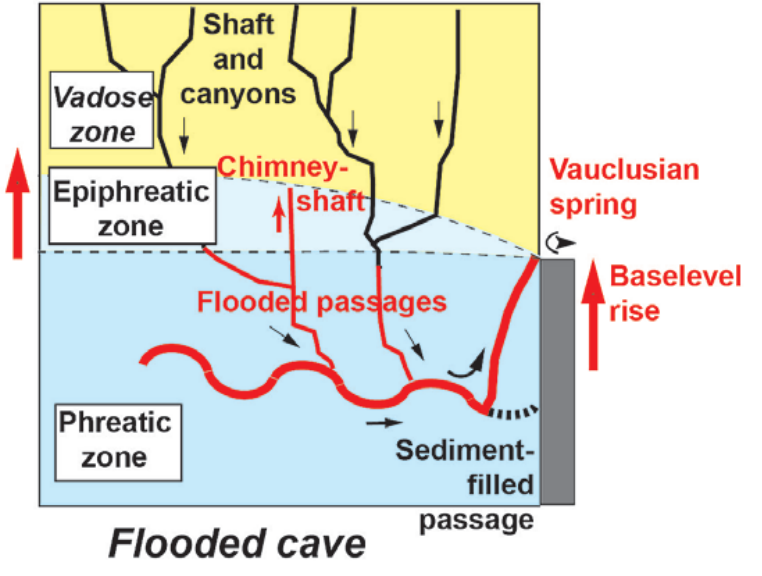

Flooded cave

Fig. 15: Influence of base-level change on cave pattern. Left: cave levels. A base-level drop causes the lowering of the karst drainage. The old drains are abandoned and remain perched. Right: Flooded cave. A base-level rise floods the deep part of the cave system. The main deep passages remain active; the water rises through a phreatic lift (chimney-shaft) and discharges at a vauclusian spring.

\section{Base-level rise, vauclusian caves and the Per Ascensum Model of Speleogenesis (PAMS)}

(Audra et al. 2009a)

Per ascensum is used here for cave originating from a deep loops in which meteoric water rises. Such flow can be influenced by local recharge. It strictly differs from hypogenic speleogenesis, where rising water is not directly connected to nearby recharge areas (see 2.1), and where hydrology is generally characterized by its regularity.

The depth that phreatic loops can extend below the water table is a matter of debate (Audra \& Palmer 2013; Ford 2014). Some water-filled passages have been dived through their springs to depths of several hundred meters, at the limit of present-day techniques, and yet they still continue downward out of sight (Exley 1994). Most are located along major faults. Lift tubes up to $100 \mathrm{~m}$ in relief have been mapped in caves in Sarawak, Malaysia (Farrant \& Smart 2011; Farrant et al. 1995). They are now abandoned and resemble vertical shafts.

Rises in base level cause flooding of conduits. Some become sediment-filled, but the main flow lines remain active (Fig. 15). New ascending routes, or reactivation of relict conduits, may form phreatic lifts (chimney-shafts) and vauclusian springs such as Fontaine de Vaucluse, France. In Mediterranean karsts, the Messinian Salinity Crisis induced first a deepening of the karst systems, then a flooding after the Pliocene transgression, and finally a reorganization of the drains after this base level rise (Audra et al. 2004, 2009a). This is the reason why deep phreatic cave systems are so frequent around the Mediterranean basin (Fig. 16, 17).

Currently, some cave systems remain flooded and others have been partly or entirely drained after Pleistocene re-entrenchment of the valleys. In partly exhumed canyons, the lower part of the karst has remained flooded since the beginning of the Pliocene, and they discharge

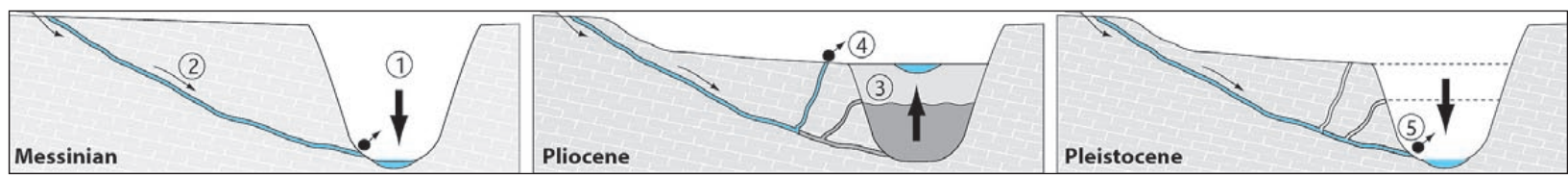

Fig. 16: Per ascensum model of speleogenesis (PAMS) during the Messinian-Pliocene cycle around the Mediterranean (Audra et al. 2004, 2009a). Left. During the Messinian, the Mediterranean drying-up caused the entrenchment of canyons (1) and the deepening of karst drainage (2). Center. Pliocene base level rise occurred in two steps - by marine ingress (dark gray - 3), then by fluvial aggradation (light gray - 4). Deep drainage uses phreatic lifts to emerge as vauclusian springs, recording successive positions of the base level. If the Messinian canyon is located below the current base level, it remains buried; the karst remains flooded and discharges by a vauclusian spring (Fontaine de Vaucluse type). Right. If the Messinian canyon is located above the current base level, the canyon is eventually exhumed and the karst is drained. The current drainage reuses the deep Messinian drain (5); the Pliocene phreatic lifts are abandoned as fossil "chimney-shafts". 


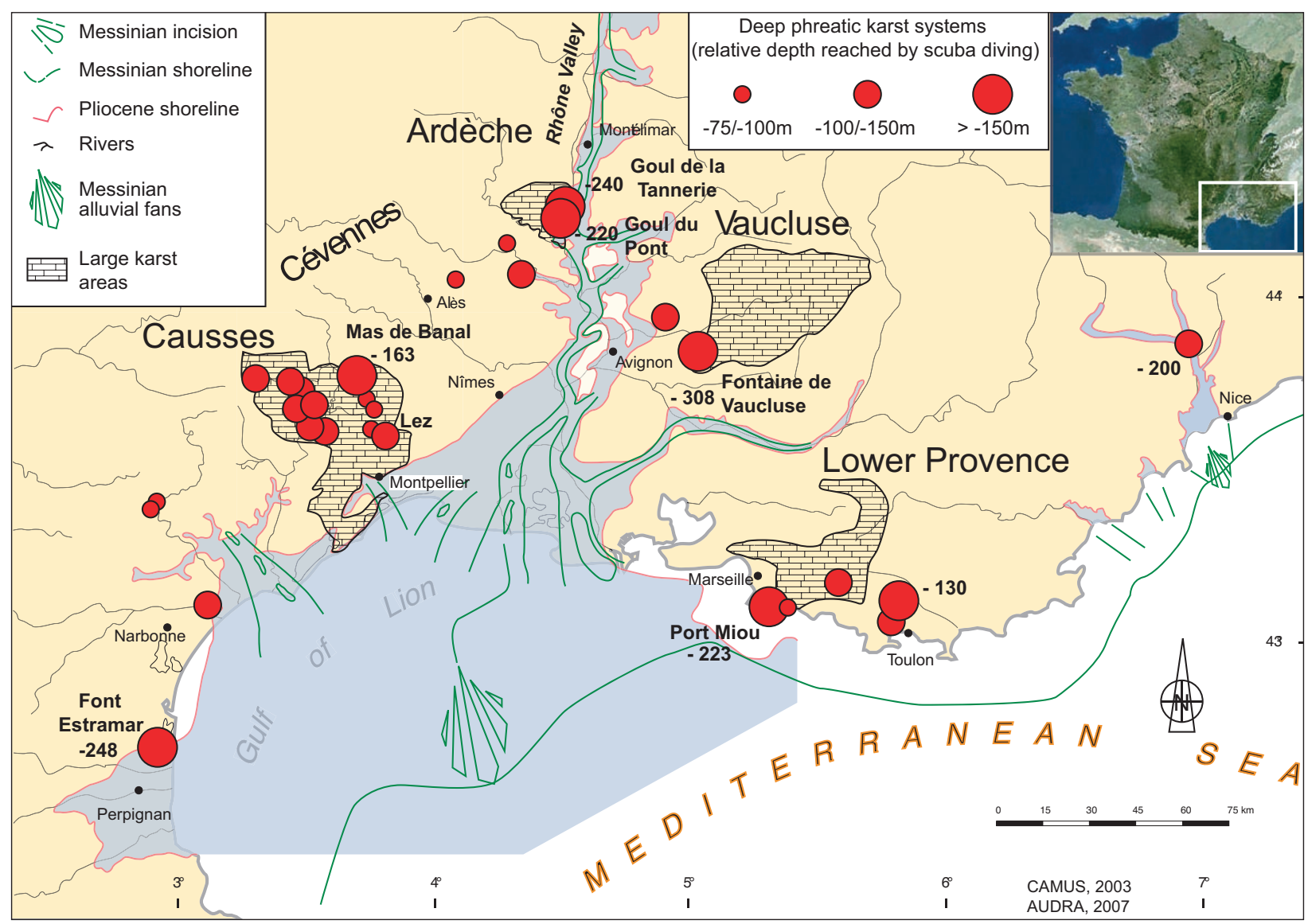

Fig. 17: Deep-phreatic cave systems in Mediterranean France. All cave systems are connected to the Mediterranean or to the Pliocene rias ("flooded valleys").

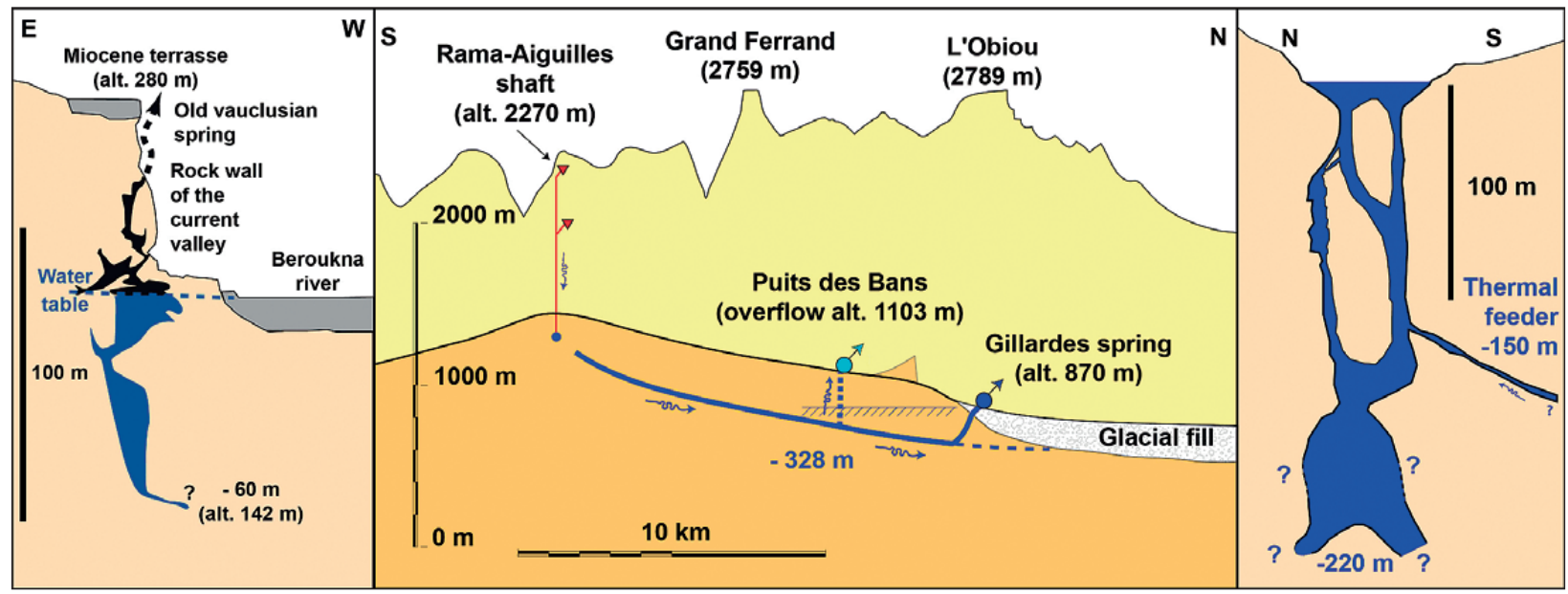

Fig. 18: Per ascensum model of speleogenesis, caused by eustatism, valley filling, and tectonic, respectively.

Left: Podtratová jeskyně, Moravian karst, Czech Republic, a 140-m high chimney-shaft, the lowest part of which is flooded below the Beroukna valley (Bruthans \& Zeman 2003). It may show a record of the base-level rise of the hydrologic network after pre-Badenian entrenchment.

Center: The Puits des Bans and the Gillardes Spring, French Alps. The basin fill (glacial, lacustrine, and fluvio-glacial) has blocked the Gillardes Spring. In high water, the Puits des Bans, a 300m-high chimney-shaft, floods and overflows.

Right: Lagoa Misteriosa, Brazil, a 200-m deep ascending shaft, a window in a karst aquifer flooded after continental subsidence of the Pantanal region (survey by G. Menezes). A hydrothermal feeder also points at least partly toward a hypogenic origin. 
as vauclusian springs (Fontaine de Vaucluse type) (Fig. 16 , center). In the entirely exhumed canyons, the karst is now drained and the chimney-shafts are fossil (Fig. 16, right).

Other causes of base-level rise (marine transgression, fluvial aggradation, continental subsidence), that are less significant in amplitude have the same effect on per ascensum speleogenesis (Fig. 18). The deep karst is flooded and phreatic lifts connect to vauclusian springs.
Consequently, there should be a global genetic model for most deep-phreatic systems. Some of them have a hypogenic origin (part 2 of this paper). However, most of them could correspond to a base-level rise inducing the per ascensum speleogenesis, which first flooded the karst and then allowed the development of phreatic lifts, "chimney-shafts", and of vauclusian springs.

\section{HYPOGENIC SPELEOGENESIS}

A constantly increasing number of caves are being classified as hypogene caves since their clear distinction occurred only a few years ago (Klimchouk 2007, 2009).

\section{HYPOGENIC SPELEOGENESIS DEFINITION}

The definition of hypogenic speleogenesis has been strongly debated during the recent decade (for detailed discussion, see Dublyansky 2014, and references therein). Actually, it was difficult to consolidate under a unique category caves as different as thermal, sulfuric, cold meteoric, mineralized with ore deposits, breccia pipes and sagging structures, huge horizontal or 3D mazes, giant ascending shafts, etc. Successive attempts focused on geochemistry, stressing the deep-seated origin of aggressivity (Palmer 1991, 2000), or on hydrogeology, pointing out the rising direction of upwelling (Klimchouk 1992, 2007), and on geomorphology, trying to classify caves patterns according to flow type and structural setting (Audra et al. 2009).

The greatest support for hypogenic speleogenesis is given by Klimchouk (2007, and earlier papers) as the formation of solutionally-enlarged permeability structures by the upwelling groundwater flow, independent of recharge from the overlying or immediately adjacent surface. The upwelling is focused along main regional fault lines allowing cross-formational flow.

As a consequence the following trends are generally observed for hypogenic speleogenesis:

- From a geochemical point of view, caves are generated by upwelling water in which the aggressiveness has been produced at depth beneath the surface, independent of surface or soil $\mathrm{CO}_{2}$ or other near-surface acid sources (Palmer 2000). Such aggressiveness involves deep-seated sources of $\mathrm{CO}_{2}$, of sulfides, and/or thermal processes (see below). Accordingly, water chemistry often shows significant higher concentrations in sulfides, sulfates, or dissolved carbon dioxide, together with metals and trace el- ements. Due to consumption of oxygen at shallow depth below the recharge areas, deep upwelling waters are generally depleted in oxygen, i.e., reducing, allowing transport of metallic species which otherwise are not mobile and precipitate in oxidized conditions. Incidentally, this is the genesis of "hydrothermal" ores, which represent in karst environment some of the largest concentrations such as MVT deposits.

- Deep water contribution is the most frequent case. However some variants involve cold meteoric freshwater, such as artesian waters rising across evaporites where aggressiveness is not produced at depth and do no rely on any acids (Klimchouk 2013).

Water that rises rapidly from considerable depth can remain relatively warm compared to the local surface groundwater, within a range of a couple of degrees above the average temperature up to sometimes almost $100^{\circ} \mathrm{C}$. Again, if thermalism is frequent or at least visible with slight temperature anomalies, some cases cases involve »normal " cold temperature, such as Frasassi Caves (Galdenzi \& Menichetti 1995).

- Due to the considerable distance between recharge and discharge areas often reaching dozen of kilometers or more, groundwater flow is driven by regional hydraulic gradients, rather than by local shallow gradients, with permeability mostly provided by porosity and fissures, rather than conduits such as those in epigenic karst. As a consequence, outflows are generally not, or only weakly, influenced by rain events or seasonal climatic cycles, displaying regular flow rates with low velocity. Mineralization is much more stable, and no solid load is observed.

Deep upwelling water is rarely of a pure deep origin. Cross-formational rising flow tends to mix with successive types of water encountered during the upwelling along faults, each defined aquifer having its specific characteristic. The uppermost aquifers are influenced more by meteoric recharge, up to surficial aquifers of "pure" meteoric fresh water. Accordingly, deep water mixes with 
various amounts of shallower waters, which are less mineralized, colder, and more oxygenated. Solid load from typical epigenic karst aquifer can also be incorporated at shallower depth. Between "pure" deep and shallow water end-members, all intermediate types of mixing can occur, and the outflow may be more or less influenced by the surface following recharge events, with decreases in temperature and mineralization, discharge, turbidity and bacteriological peaks, whereas long recessions allow the return of low discharge of less influenced deep water.

- Due to the typically long distances of their rising water, hypogenic caves tend to have no relation to karst features formed by surficial processes. They can, however, help to form surface features by collapse into hypogenic voids. Hypogenic caves are often located where typical surficial karst features are absent, in low cave density areas, simply because of the speleogenesis having a deep-seated origin that focuses toward the surface along discrete fractures. Except for their deep-rooted source, however, their relationship with the surface is strongly dependent to topography, since discharge areas tend to be located in topographic lows (e.g., valleys) where groundwater flow converges and wells up. Accordingly, these convergences produce a positive feedback that may partly explain the presence and development of piedmont and plain valleys. And since discharge areas, where hypogenic speleogenesis is focused, are commonly located in areas of low topography, hypogenic caves often represent excellent proxies for base-level records and highly valued milestones for the reconstruction of landscape evolution over long time spans.

- Hypogenic speleogenesis, i.e. mainly due to deep water upwelling, must not be confused with meteoric deep phreatic loops, such as vauclusian systems. Epigenic cave systems may have deep phreatic loops, reaching sometimes several hundreds of meters. Vaucluse spring, in France, reaches at least $300 \mathrm{~m}$ deep (see "base level rise" in this paper). In such vauclusian epigenic systems, water is simply flowing along deep loops before discharging. Consequently, the speleogenetic processes are typically epigenic. Springs are highly influenced by irregular recharge with a large range of discharges and unstable mineralization.

\section{HYPOGENIC SOLUTIONAL PROCESSES}

Many solutional processes from upwelling hypogenic flow account for speleogenesis (Klimchouk 2007, 2013a; Palmer 2000, 2013). Among the following, one process is dominant but generally combines with one or more secondary processes.

- Dissolution of evaporites, in fact simple dissociation, which occurs when meteoric undersaturated water enters from below. Such a process accounts for the giant maze caves in gypsum in Ukraine and elsewhere (Klimchouk 2000a; Vigna et al. 2010).

- Carbonic acid solution due to deep-seated sources of $\mathrm{CO}_{2}$ such as volcanism, mantle, and metamorphism (Gary \& Sharp 2009).

- Increasing solubility of calcite along ascending flowpaths due to water cooling, which is frequently called "hydrothermal speleogenesis".

- Sulfuric acid solution. Deep sulfate beds are first converted to $\mathrm{H}_{2} \mathrm{~S}$ in presence of hydrocarbons (petroleum, methane) or organic carbon from marls. Deep $\mathrm{H}_{2} \mathrm{~S}$-rich upwelling water mixes with shallow meteoric oxygenated water, producing sulfuric acid. This process commonly called "sulfuric acid speleogenesis" (SAS), occurs at shallow depth in the phreatic zone but especially above the water table due to $\mathrm{H}_{2} \mathrm{~S}$ degassing in cave atmosphere (see below). It accounts for some of the largest hypogenic caves in the world, such as Lechuguilla Cave and Carlsbad Cavern in New-Mexico (Hill 1987; Palmer \& Palmer 2000a; Polyak et al. 1998).

- Hydrosulfuric acid solution. This process may occur at depth around reduction zones. However, since simultaneous oxidation of hydrocarbons leads calcite to supersaturation and $\mathrm{H}_{2} \mathrm{~S}$ is a weak acid, such a process remains marginal (Palmer 2013).

- "Mixing corrosion" of waters of contrasting chemistry. Such a process may occur along upwelling flowpaths when given water mixes with the encountered water body, including shallow meteoric waters. Mixing corrosion is probably the most active process a depth, when different solutions are converging. At depth, mixing of waters of contrasting $\mathrm{H}_{2} \mathrm{~S}$ content can produce undersaturated solutions (Palmer 1991). This process must take place in a closed system to prevent $\mathrm{H}_{2} \mathrm{~S}$ from oxidizing, as well as loss of any $\mathrm{CO}_{2}$ generated by the dissolution reaction.

- Common-ion effect with mixing of sulfates and carbonates producing dedolomitization.

- Other process may occur at depth involving organic acids at high temperature conditions, and silica solution in alkaline, high temperature and high pressure conditions.

\section{SPECIAL FOCUS ON SULFURIC ACID SPELEOGENESIS (SAS) AND CONDENSATION- CORROSION}

The voids in SAS caves are mostly formed above the water table by waters which dissolving capacity is enhanced by abiotic and/or biotic oxidation of $\mathrm{H}_{2} \mathrm{~S}$ deriving from a deep source (Galdenzi \& Maruoka 2003). $\mathrm{H}_{2} \mathrm{~S}$ can be generated by volcanic activity, reduction of sulphates such as gypsum or anhydrite, in the presence of hydrocarbons (petroleum, methane) or organic carbon from marls, and is brought to 
the surface through deep tectonic structures. The origin of the sulphur can usually be ascertained using its stable isotope signature and that of its possible sources (Onac et al. 2011). The oxidation of $\mathrm{H}_{2} \mathrm{~S}$ produces sulphuric acid that reacts instantaneously with the carbonate host rock producing replacement gypsum and carbon dioxide. $\mathrm{CO}_{2}$ can dissolve in water again and increase its aggressiveness even more. Also the local oxidation of sulphides, such as pyrite, often present in carbonate sequences, can generate sulphuric acid, boosting rock dissolution (Tisato et al. 2012; De Waele et al. 2016).

Sulphuric acid also reacts with other minerals such as clays and can cause the formation of a typical suite of sulphates including jarosite, alunite, halloysite, basaluminite, etc. Some of these minerals, especially those containing potassium such as alunite and jarosite, can be dated with radiogenic methods (Polyak et al. 1998). Also gypsum can be dated using the U/Th method (Sanna et al. 2012; Piccini et al. 2015). The ages of minerogenesis exactly corresponds to the most recent phase of cave formation, when the SAS process was active. Thus SAS byproducts offer a unique opportunity to date the speleogenesis phases, on the contrary to other classical methods where dating is made on the cave filling, which postdates the cave itself.

Sulphuric acid caves are thus often intimately related to the contact zone between the water level, from which $\mathrm{H}_{2} \mathrm{~S}$ rises, and the air. Enlargement of the voids mainly happens by condensation-corrosion processes in a highly acidic environment (Audra et al. 2007). Condensation is greatly enhanced in the presence of thermal differences between the upwelling waters and the cave walls and atmosphere, even in low thermal environment where the temperature contrast reaches only a few degrees (Gàzquez et al. 2015; Sarbu \& Lascu 1997). Dissolution of carbonate rock in these conditions is extremely fast compared to normal epigenic caves and can cause the formation of sizeable cavities in probably only a few thousands of years.

\section{HYDROGEOLOGICAL SETTING}

The principle of hypogenic speleogenesis relies on recharge at distance or at depth, slow transfer at depth, and focused discharge in topographic lows, typically along faults allowing fast and easier cross-formational upwelling. Flow transfer in the upper portion of basins is described by the "Regional Gravity Flow" concept (Tóth 1970, 2009), adapted to hypogene speleogenesis by Klimchouk $(2013$ b, c). Topographic highs act as recharge areas, whereas topographic lows act as discharge areas (Figs. 19, 22). At shallow depth, local loops of meteoric water are dominant. For deep aquifers within gravity-driven meteoric flow, most of the marginal recharge is discharged in marginal areas, whereas the internal area of the basin displays mainly vertical flow, with very low contribution of lateral flow from basin margins (Fig. 19). In confined aquifer systems, lateral flow is dominant in more pervious units, whereas vertical flow is dominant in less pervious units. Klimchouk (2013b,c) distinguished several hydrogeological settings with different regularities of localization of upwelling flows and hypogenic speleogenesis. These include large cratonic artesian basins (divided in marginal areas, internal areas, and deep zones), coastal aquifer systems in large carbonate platforms, fold/thrust regions, young disrupted intramontain basins, and areas of young volcanism. We follow his hydrogeological typology in the next paragraphs.

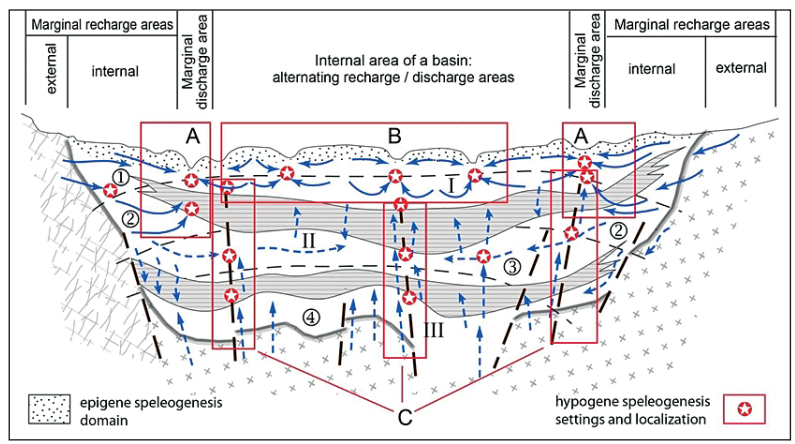

Fig. 19: Regional hydrodynamics of a basin showing decrease in communication and a progressive shift from lateral to ascending flow with depth. Boxes distinguish marginal areas (A), internal areas (B) and deep zones (C). Hypogenic speleogenesis occurs in zones of convergence, where mixing occurs (Klimchouk 2013c, after Vsevolozhskiy 2007).

\section{Marginal basin areas}

In marginal areas of the sedimentary basins, meteoric water descending from recharge areas mixes with deep basinal water and wells up along topographic lows (typically river valleys), forming a belt of hypogenic speleogenesis with large sinkholes corresponding to deep breccia pipes and sagging zones (Fig. 20). Numerous examples are present in USA, for example the Roswell basin feeding the Pecos River (Land 2003), and the Prairie aquifer in the Western Canadian Basin (Wright 1984). Most of the German caves -excluding epigenic alpine caves- in Iberg-Harz, Swabian Alb and Franconian Alb seem to be related to a similar hydrogeological context (Kempe 2014a, b). In the NW European coal basin stretching between Northern France and Belgian Hainault, such breccia pipes were first described in XIX ${ }^{\text {th }}$ century and called "geological orgues" (organs), "Dièves shafts" (Renault 1970) or "crans" (Quinif 1994). They are buried under upper cretaceous strata, some 


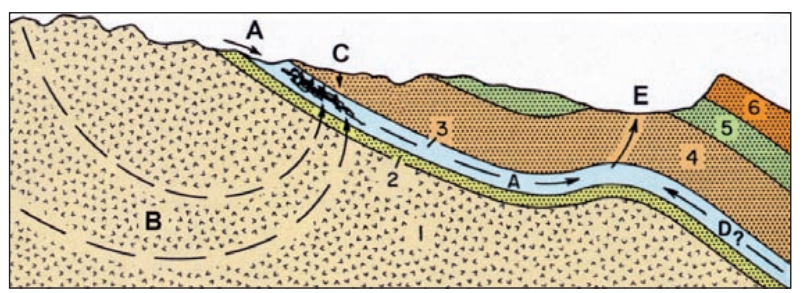

Fig. 20: Cave development along the margin of low-permeability igneous-metamorphic rocks, Black Hills, South Dakota (Palmer \& Palmer 2009). $A$ = direct recharge from the surface; $B=$ deep groundwater flow through Precambrian rocks; $C=$ infiltration through thin sandstone; $D=$ recharge from deep within the aquifer (questionable); $E$ = discharge to springs through confining beds. There is evidence that infiltration through the sandstone $(C)$ achieves low $\mathrm{PCO}_{2}$ by closed-system dissolution at the top of the limestone and regains aggressiveness where it mixes with deeper water from $A$ and perhaps B, e.g., at Wind and Jewel Caves.

reaching a depth of $1200 \mathrm{~m}$, and contain dinosaurs. In the Crimean Piedmont deep upflow toward sedimentary cover is focused along a suture zone (Fig. 21).

\section{Internal basin areas}

In the upper hydrogeological storeys of internal areas of the basins, the layered aquifer/aquitard system displays topography-controlled flow pattern (Klimchouk 2013c). In aquitards, vertical flow is predominant with downward cross-formation communication below topographic highs and upward communication below valleys (Fig. 22). Large valleys can induce upward flow with vertical relief up to $1.5 \mathrm{~km}$. In aquifers, lateral flow is directed from topographic highs to lows. Because of relief undulations, areas of recharge with downward flow alternate with discharge areas with upward flow. In Podolia plain, Ukraine, meteoric water flowing in a limestone aquifer flows upward through gypsum strata making the largest gypsum maze caves in the world.

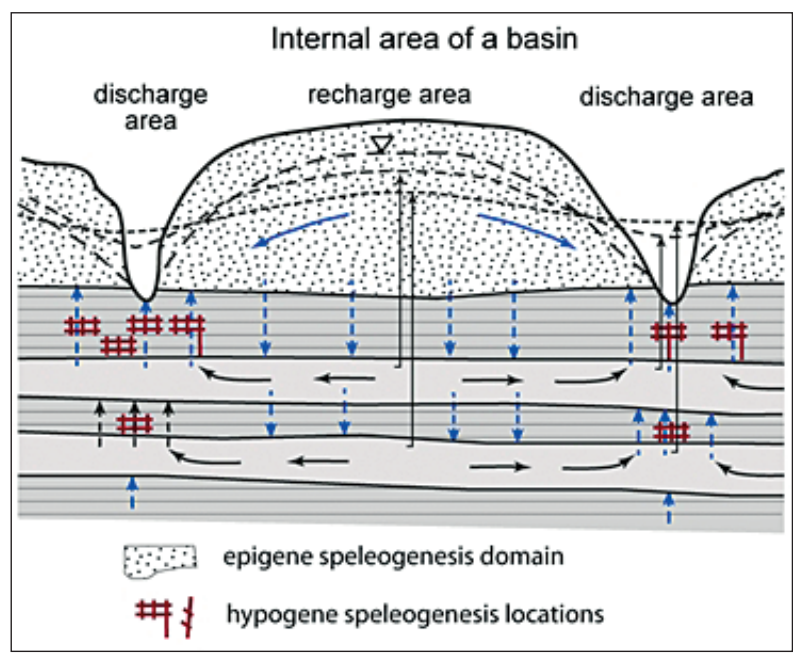

Fig. 22: Alternation of recharge areas with downward flow and discharge areas with upward flow fed by convergence of lateral flow in aquifers and cross formational upward flow across aquitards. Hypogenic speleogenesis focuses in convergence zones where undersaturated water enters the aquifer from below (Klimchouk 2013b).

\section{Basin deep zone}

In deep basinal zones, flow is predominantly vertical along blocks and faults where deep fluids from the basement and upper mantle are rising and mix with upper stratiform aquifers (Klimchouk 2013b). Flow and pressure are highly irregular. Physical-chemical parameters evolve along upwelling flowpaths causing selective solution and precipitation. Thermal and geochemical anomalies thus develop in the upper storeys (Fig. 23).

\section{Coastal basins}

Coastal basins represent a variant where sea water plays the part of the confined basin internal area. Upward flow in the coastaland submarinedischargezonecanbedriven byboth

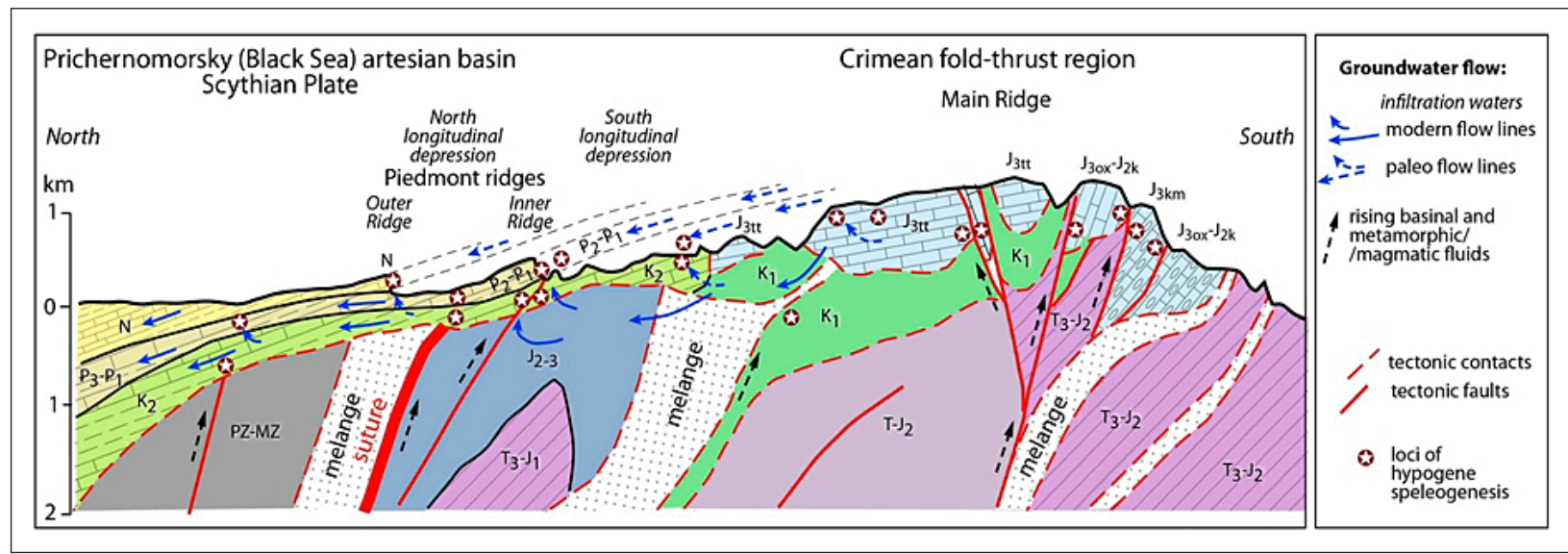

Fig. 21. In the Crimean Mountains, deep flow upwelling along faults of the suture zone mixes with lateral flow in stratified aquifers of the Black Sea basin margin, where hypogenic karstification takes place (Klimchouk 2013c). 


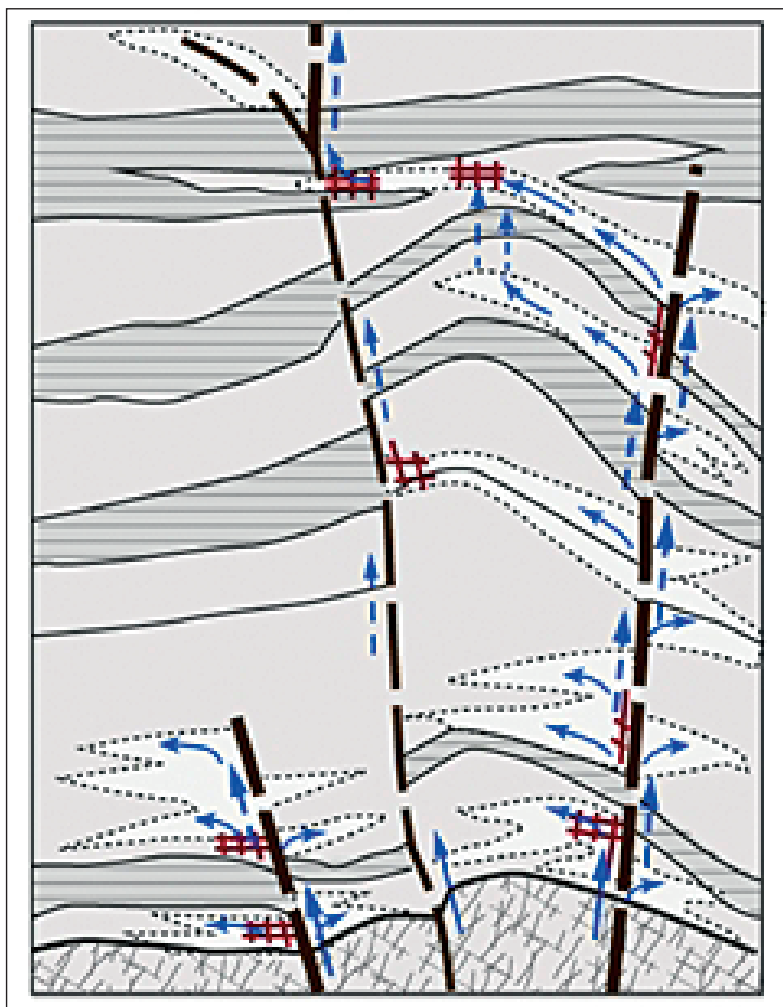

\section{\# hypogene speleogenesis locations}

Fig. 23: In deep zones, flow partly originating from the basement or mantle is mainly vertical along faults, producing strong physical-chemical contrasts where dissolution occurs (Klimchouk 2013b)

topography-induced head and density gradients where freshwater aquifers extend below saline water aquifers and the seawater, plus geothermal heating of seawater entering the platform at deep levels (Fig. 24). In Florida and Yucatàn, thermal and chemical anomalies are observed in the aquifer, together with "cenotes" revealing solution down to considerable depth (>200 m), rising springs with deep components, and huge seafloor "dolines" occurring

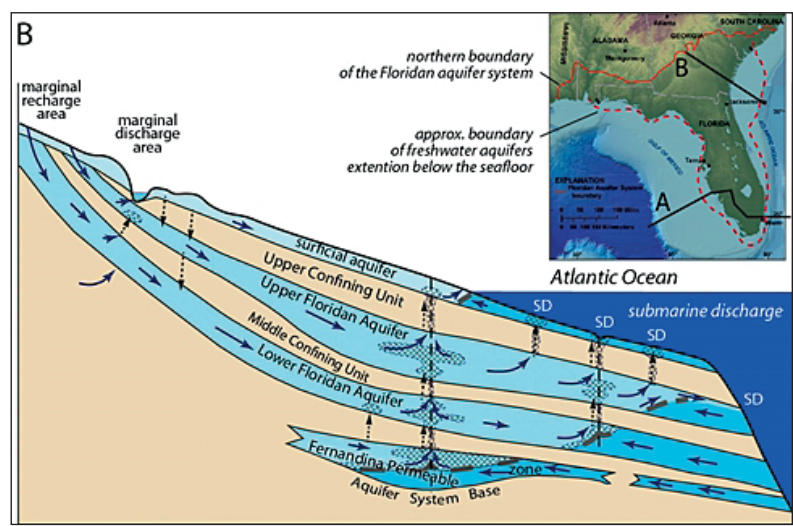

Fig. 24: In coastal basins confined by seawater, such as Florida, topographic head, density gradients and thermal heating produce upflow and dissolution in convergence and mixing zones, revealed by cenotes and off-shore depressions (Klimchouk 2013c, after Krause \& Rundolf 1989 and Spechler 1994)

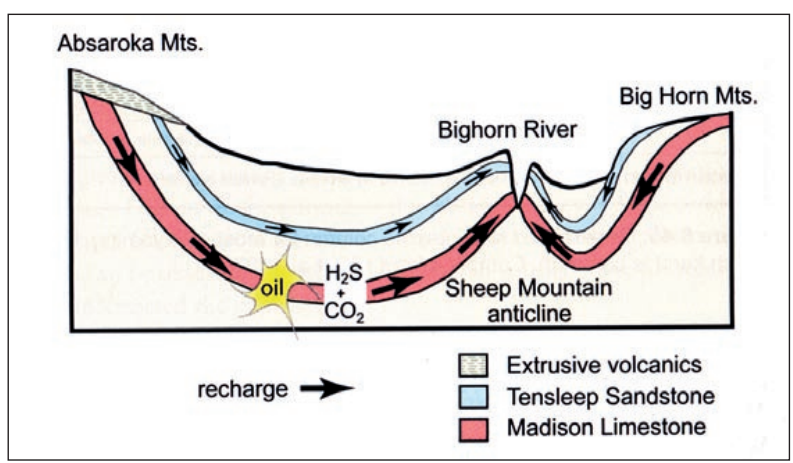

Fig. 26: The Bighorn River cut through the Sheep Mountain anticline allowing upflow of a deep aquifer discharging sulfuric water at Kane Caves, Wyoming, USA (Palmer \& Palmer 2009, after Egemeir 1981).

offshore at depths up to $600 \mathrm{~m}$ (Cunningham \& Walker 2009; Thomas 2010; Klimchouk 2013c).

\section{Deformed strata}

In deformed strata, as in marginal areas of the sedimentary basins, meteoric water descending from recharge areas

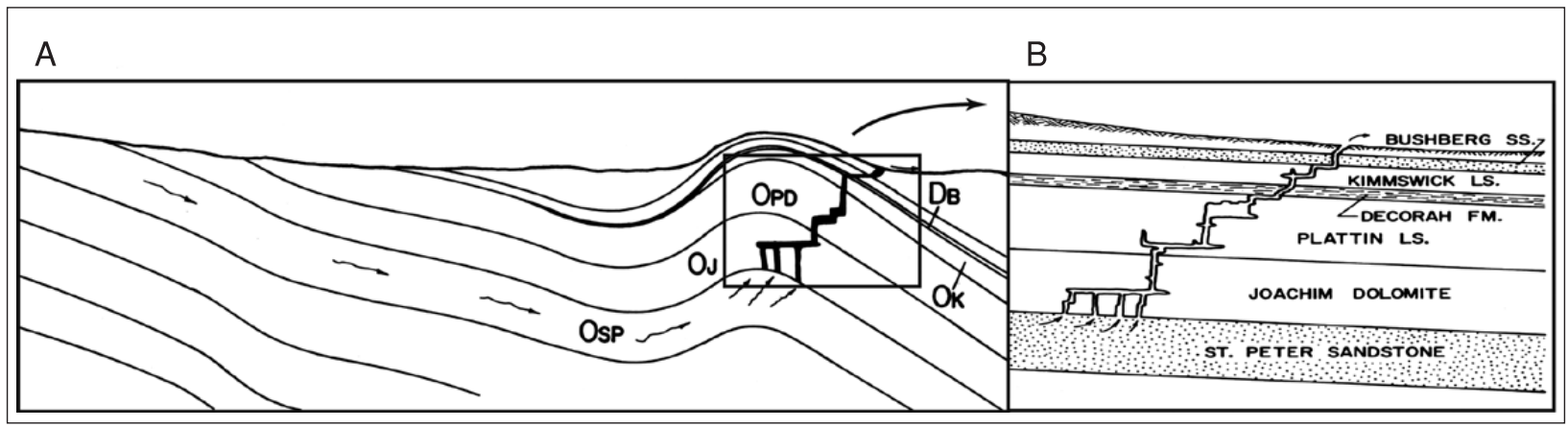

Fig. 25: Upward flow of groundwater from a deep sandstone aquifer into overlying carbonate rocks along an anticline, where many fissure caves developed, eastern Missouri, USA (Brod 1964). 


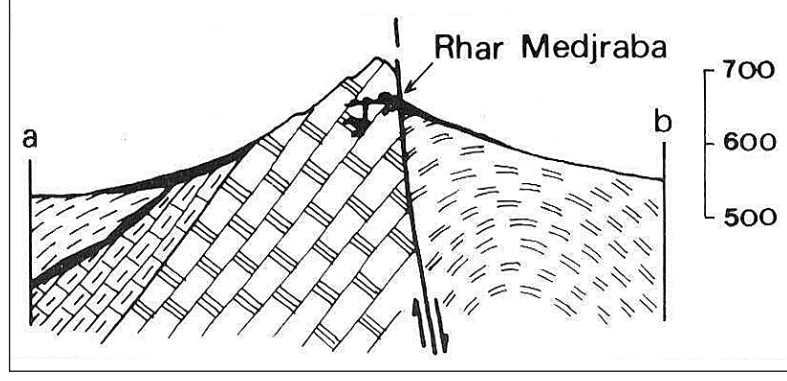

Fig. 27: The thermal aquifer now discharging at $80{ }^{\circ} \mathrm{C}$ at the foot of the Azrou anticline, Algeria, formerly discharged through caves now perched along the faulted anticline after valley incision (Collignon 1990). mixes with deep basin water and wells up along faults or highs, allowing groundwater to discharge at topographic lows. These topographic lows lows are valleys cutting through the geological structures, where valleys act as windows in the aquifer. Many valleys are incised by the influx of deep aquifer water, which has risen along brecciated zones (Camus \& Bruxelles 2013). Upflow uses anticlines such as the classical examples of Eastern Missouri, USA, recharged from underlying sandstone strata (Fig. 25) and Kane Caves in Wyoming, USA (Fig. 26). Faults that intersect anticlines provide more efficient routes for upward flow, as in Azrou Mountain, Algeria, where old perched fossil caves reflect the current sulfuric outflow at $80{ }^{\circ} \mathrm{C}$

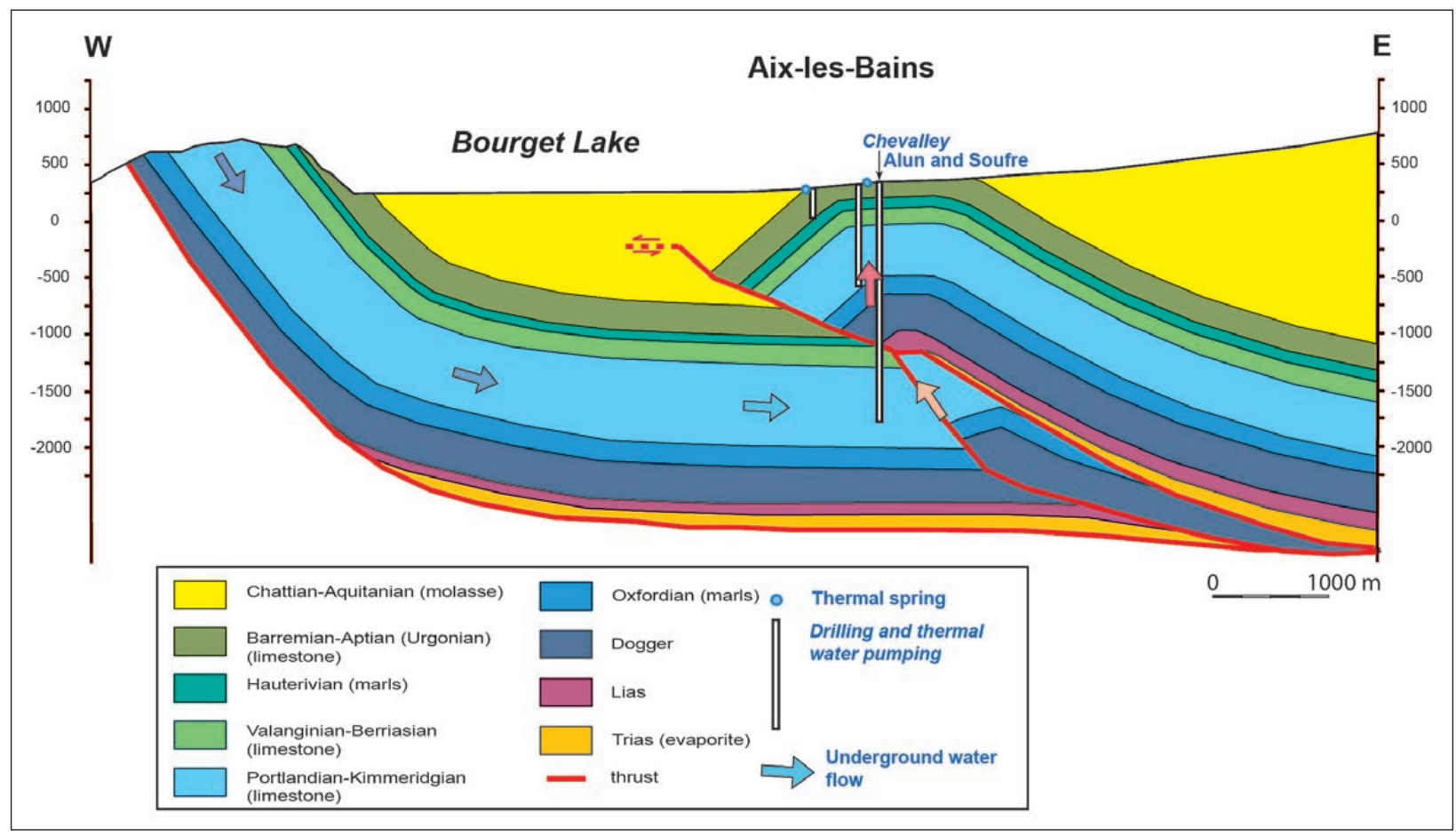

Fig. 28: The Aix-les-Bains thermal springs and caves discharge water from a deep Jurassic synclinal upflowing along the overthrusted anticline where it acquires it sulfuric component at the contact of Triassic evaporites before mixing with shallow cold meteoric water (Geology after Gallino 2007, in Hobléa et al. 2010).

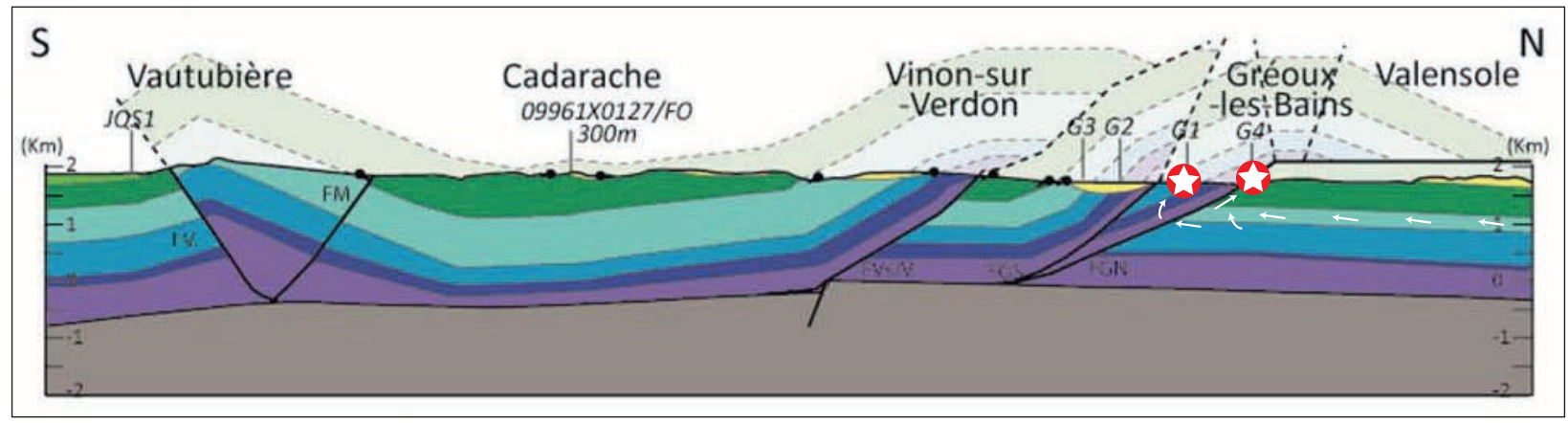

Fig. 29: Hypogenic speleogenesis (left star) focused above the overthrust allowing deep upflow, mainly from Jurassic aquifer. Current thermal spring flows at Gréoux-les-Bains (right star) (Geology after Guyonnet-Benaize 2011). 


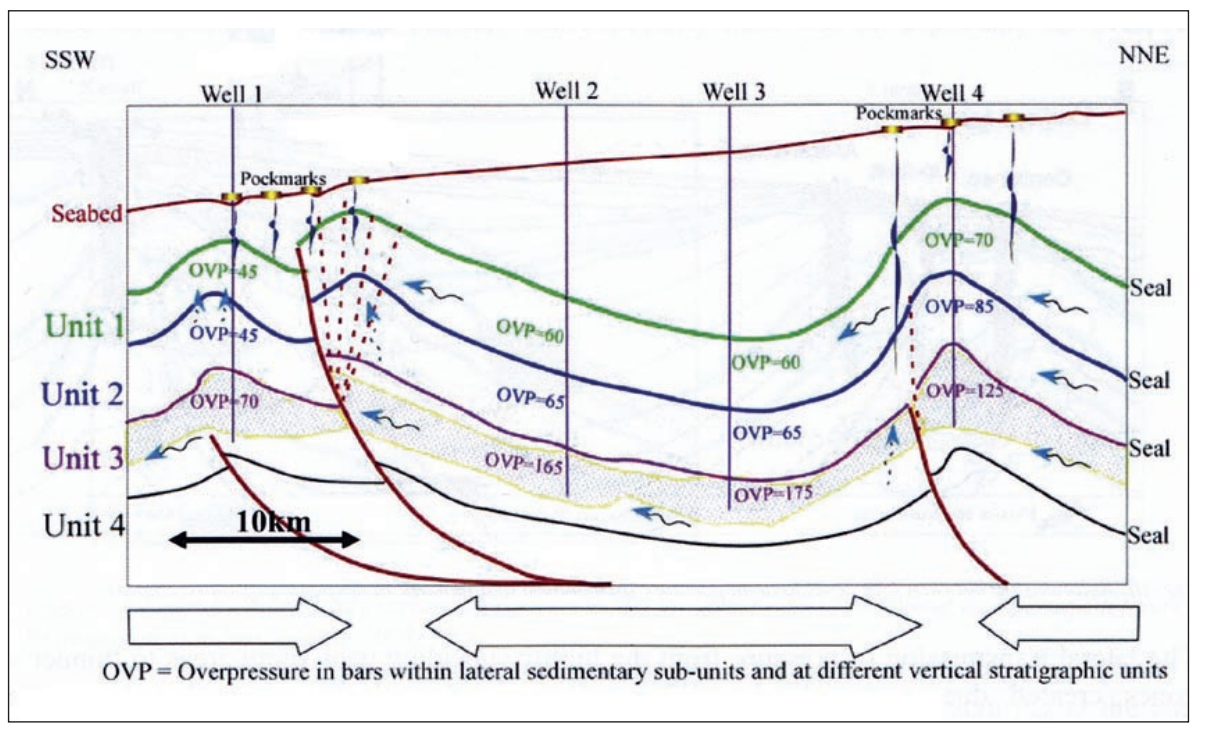

Fig. 30: The deep offshore Niger Delta, Nigeria, displays buried faulted anticlines where hydrocarbons are upflowing, making depressions at the sea bottom (Nosike 2009).

(Fig. 27). Similarly, thermal springs are due to upflow across overthrusting anticline in French Northern Alps (Fig. 28) or along overthrust in French Provence (Fig. 29). An interesting analogue is shown by geophysical interpretation of the deep offshore Niger Delta, Nigeria, where hydrocarbons migrate along faulted anticlines making belts with depressions in the sea floor (Fig. 30). Such settings could include the early phases of some hypogenic karst connected to hydrocarbon basins, such as the Guadalupe Mountains above the Delaware basin.

\section{Disrupted basins}

In disrupted basins, there is a strong gradient (topographic, hydraulic, and thermal) between displaced blocks. In the example from Budapest, Hungary, upper blocks act as recharge areas (Fig. 31). The cold meteoric water feeds both a shallow meteoric loop and deeper loops toward the basin depths. The high geothermal gradient warms up the deep water that fast rises along extensional faults. This geothermal gradient acting on water density seems to be responsible not only for the hydrothermal upflow but also for the meteoric water downflow by a "pumping effect", i.e. with the replacement of upflowing hot water by downflowing cold meteoric water. Possibly without such a thermal pumping effect at the origin of the deep loops, the meteoric water would have entirely focused along the water table and would have discharged at the foot of the hill as

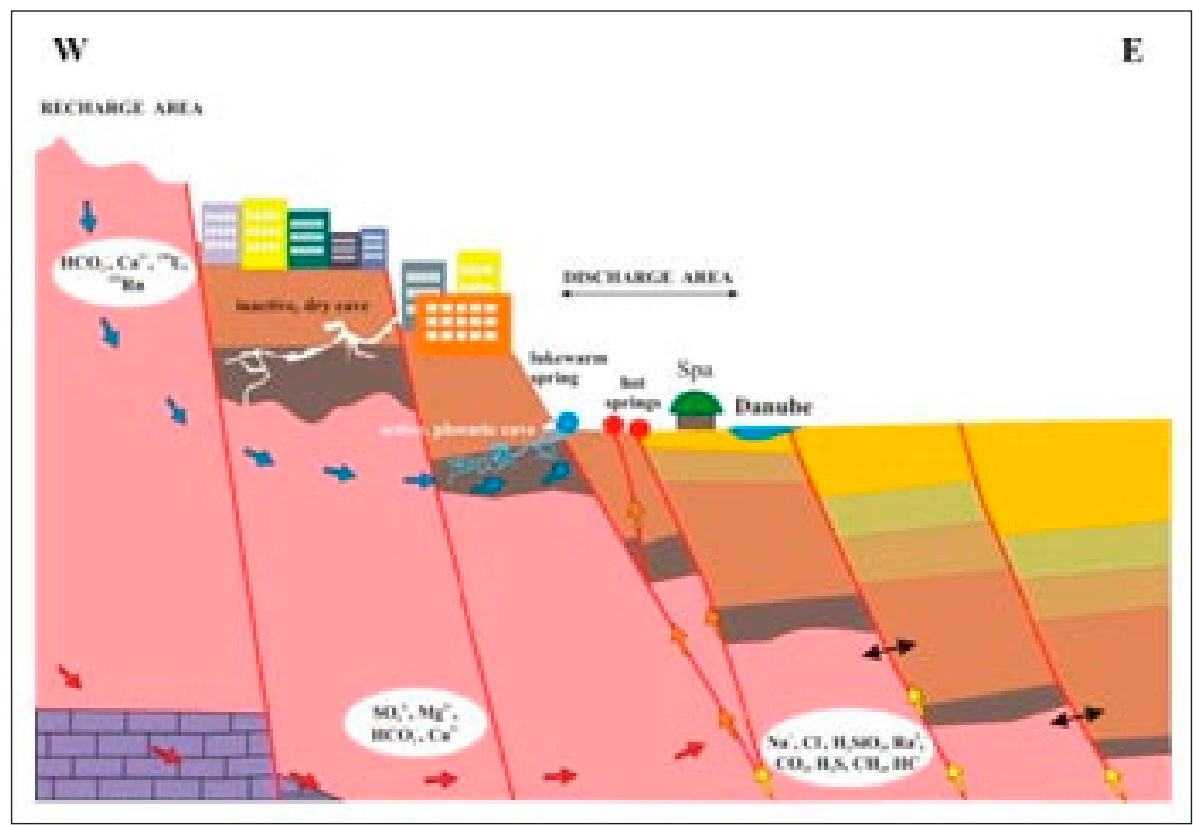

Fig. 31: Model of the Buda thermal karst, Hungary. Deep hot and mineralized water flows up from basin depth along normal faults feeding warm springs along the Danube, whereas mixing with the shallower meteoric component feeds lukewarm and less mineralized springs at the contact of the Buda hills with the development of active cave networks. Upper dry cave levels record the past position of the Danube base level (Eröss 2010). 


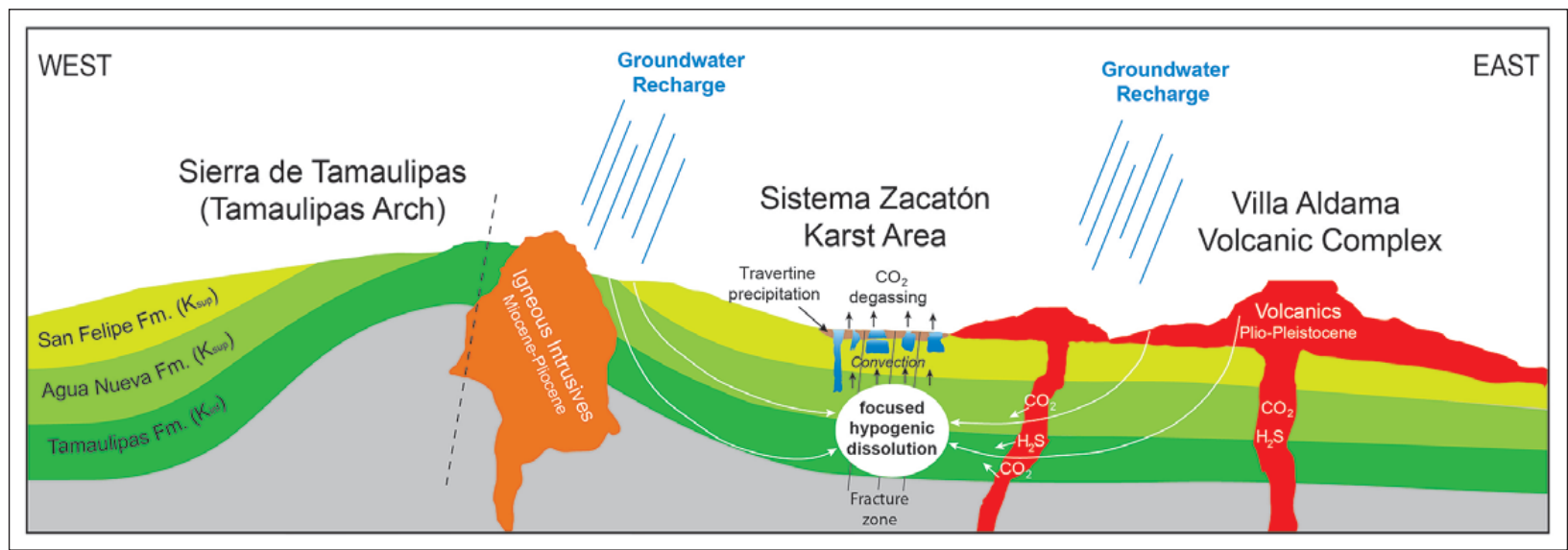

Fig. 32: Hypogenic speleogenesis of the Sistema Zacatón karst area. Groundwater flowpaths to Sistema Zacatón show enrichment of $\mathrm{CO}_{2}$ and $\mathrm{H}_{2} \mathrm{~S}$ from the Pleistocene volcanic complex to the east. The main recharge area is located to the west in the Sierra de Tamaulipas. A fracture zone focused initial flowpaths. Heat source from volcanic activity drives convection in the groundwater system (Gary 2010). The combination of acids $\left(\mathrm{H}_{2} \mathrm{~S}, \mathrm{CO}_{2}\right)$, of thermalism, and of microbial activity is boosting dissolution along fractures acting as upflow paths. Giant ascending shafts are made by enlargement of fractures and by upward stoping of large chamber at depth that eventually open to the surface. This kind of "hyperkarst" generates the deepest phreatic shafts of the Planet.

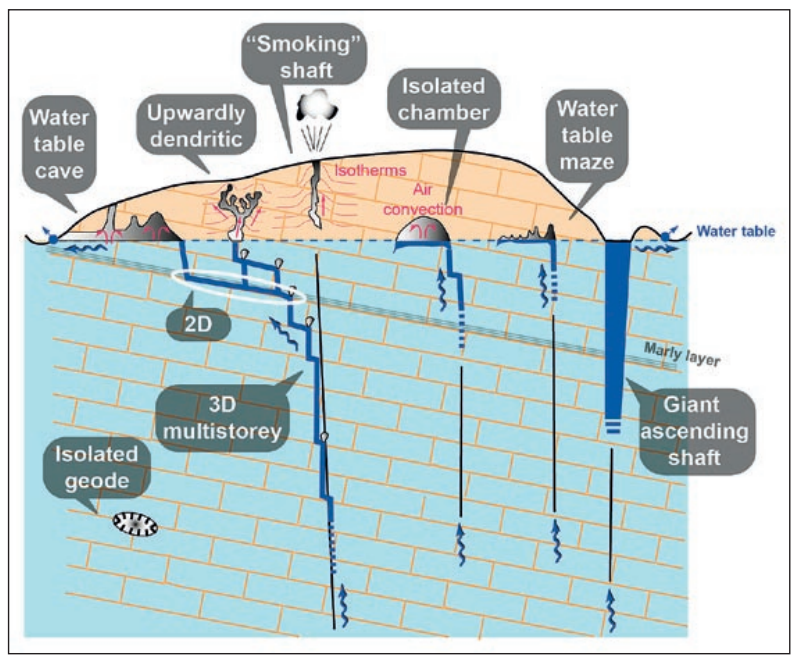

Fig. 33: Conceptual model of most typical hypogenic cave types, according to geological structure and type of flow (Audra 2007, $2009 b, c)$.

"normal" epigenic karst springs without a significant deep component. Since the shallow cold meteoric loop is restricted below the uplifted blocks, different kinds of thermal springs occur: direct thermal outflow along basin faults makes hot thermal spots along the Danube River, whereas faults between the basin and the uplifted blocks allow mixing of the hot deep upflow and the cold meteoric downflow, resulting in lukewarm springs and cave development at the foot of the hill. The fossil perched cave tiers record the position of the base level and the gradual incision of the Danube in the Pannonian plain (Szanyi et al. 2012).

\section{Volcanic and magmatic intrusions areas}

Volcanic and magmatic intrusions are a source of deep acids and heat. The geothermal gradient acts as a driving force for deep upflows that can fast rise to the surface using tectonic disruptions and attracts complementary downward recharge from remote areas. The presence of concentrated acids (from $\mathrm{CO}_{2}, \mathrm{H}_{2} \mathrm{~S}$ ) boosts the dissolution. Microbial activity using sulfo-oxidant pathways strongly participates in the rock solution. This combination of geothermal gradient, deep-seated acids, major fractures, and chemoautotrophic microbial activity is so intense that it can be considered "hyperkarst" (Audra et al. 2009b, c). The main illustrative features are giant ascending shafts, which are among the deepest of the world, with known depth reaching $500 \mathrm{~m}$. Such hypogenic origin accounts for the genesis of numerous oversized karst features, evolving from solution-enlarged fractures, eventually giving collapse shafts, and collapse shafts over large chambers developed at depth:

Examples include Pozzo del Merro, near the Latium volcanic field, and the famous Tivoli travertines (Caramana 2002); Hranica Propast, Czech Rep., is a phreatic shaft deeper than $450 \mathrm{~m}$ which owes its origin to active deep-rooted faults of the European plate releasing deep $\mathrm{CO}_{2}$ (Geršl et al. 2011).

El Zacaton is a large collapse shaft in Tamaulipas, Mexico, derived from solution along fractures (Gary 2010) (Fig. 32).

Collapse shafts above large chambers at depth in the Northern slope of the Caucasus Mountains around Elbruz volcanic area (Klimchouk 2013b); huge collapse dolines called "Obruks" in Taurus, Turkey (Bayari et al. 2009). 


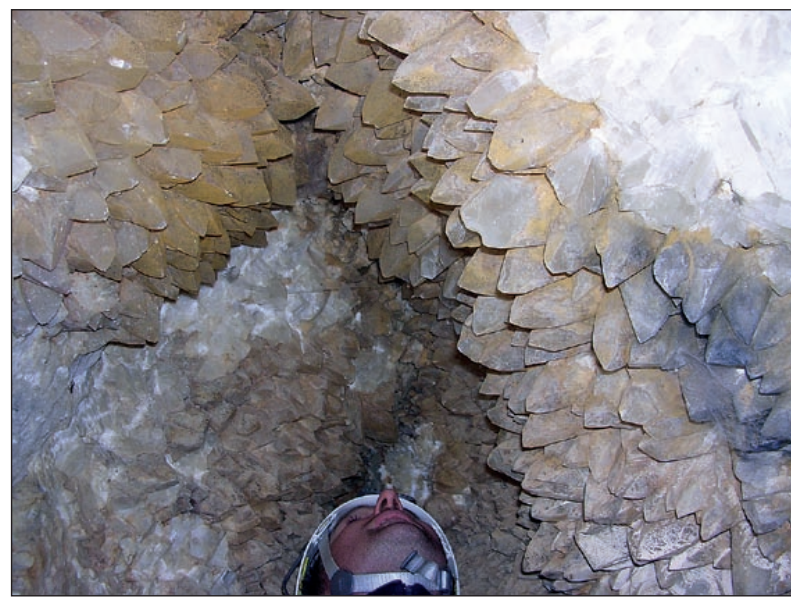

Fig. 34: Geode lined with calcite spar. Cave in Ardèche, France (Photo: P. Deconinck).

\section{TYPES OF HYPOGENIC CAVES}

A synthesis based on field experience and literature takes into account geological structure, hydrology, morphology of caves at different scales (wall features, passage morphology, and cave pattern), mineralogy, deposits, etc. The geologic framwork and speleogenetic processes can be combined into a conceptual model of cave pattern, integrating most typical hypogenic caves (Fig. 33) (Audra 2007, 2009b, c). Patterns are subdivided into two main types: deep phreatic systems generally developed in confined aquifers by transverse speleogenesis (sensu Klimchouk 2000b), and cave systems developed above the water table, where condensation-corrosion plays a paramount role.

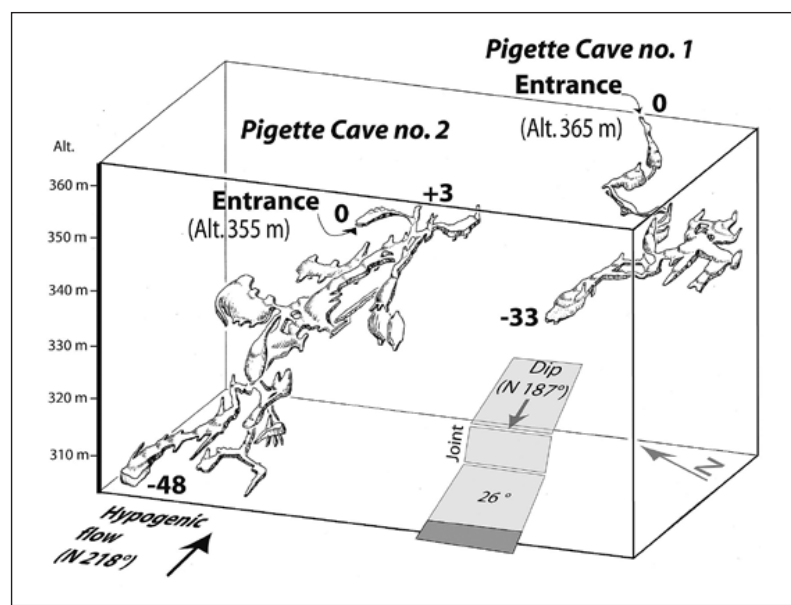

Fig. 35: Pigette Cave, Gréoux-les-Bains, France, is a 3D maze developed in the shallow phreatic zone. Rising flow enlarged alternatively bedding planes and vertical joints, producing a staircaselike pattern.

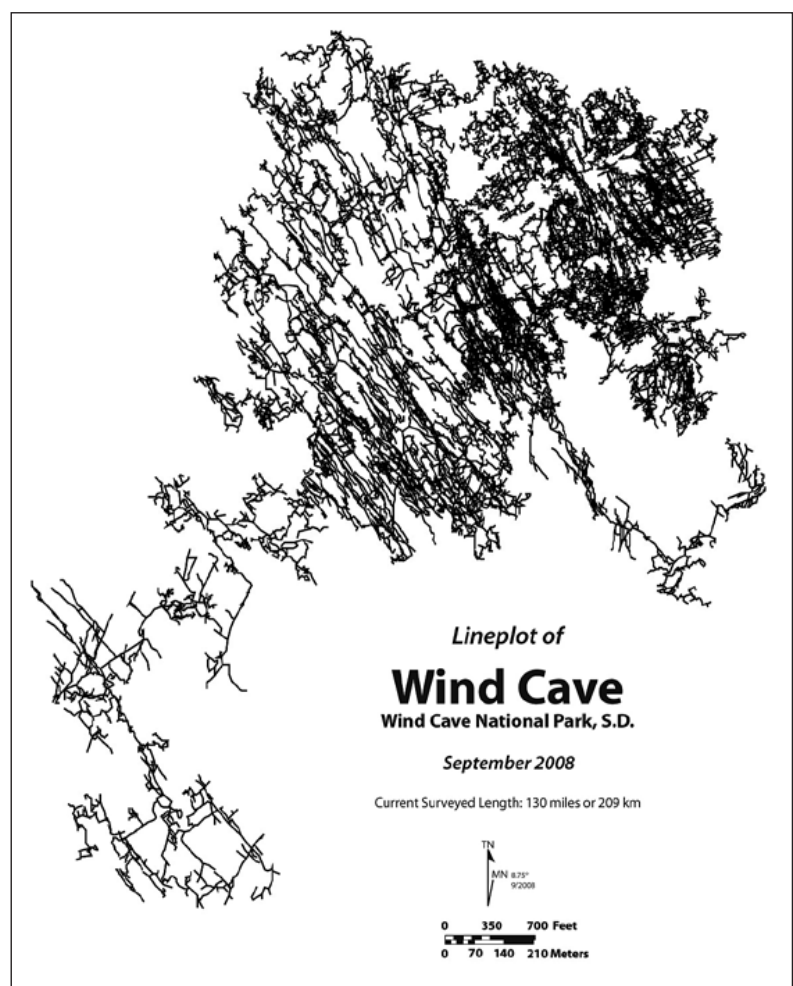

Fig. 36: Wind Cave is a $230 \mathrm{~km}$ long 3D maze cave developed along fractures in inclined strata (Map courtesy: R. Horrocks).

\section{Hypogenic cave pattern in phreatic conditions Isolated geodes}

In deep zones, vertical upflow and mixing of deep fluids of different types of water allows complex dissolution and deposition processes. Dissolution voids are poorly integrated and some are huge. Large crystals (calcite, gypsum, etc.) are deposited in slightly saturated water, together with diverse minerals (such as metallic sulfides) (Fig. 34).

\section{$3 D$ multistorey maze caves}

The rising hypogenic flow alternately follows joints and bedding planes, producing a 3D maze cave, in a staircase pattern. Generally, the cave displays a main trunk where hypogenic flow was rising, surrounded by $3 \mathrm{D}$ mazes, smaller in size (Fig. 35). Monte Cucco Cave system, Italy, with more than $900 \mathrm{~m}$ depth is the deepest known cave of this type in the world. The sulfuric water was rising toward the top of the anticline, where impervious covers are breached, allowing the discharge of the karst aquifer. Some cave entrances record past base level positions (Galdenzi \& Menichetti 1995).

In the Black Hills, South Dakota, USA, Jewel and Wind Caves rank among the largest maze caves of the world (Fig. 36). Their genesis is complex, involving several early phases (Palmer \& Palmer 2000b). The pattern 

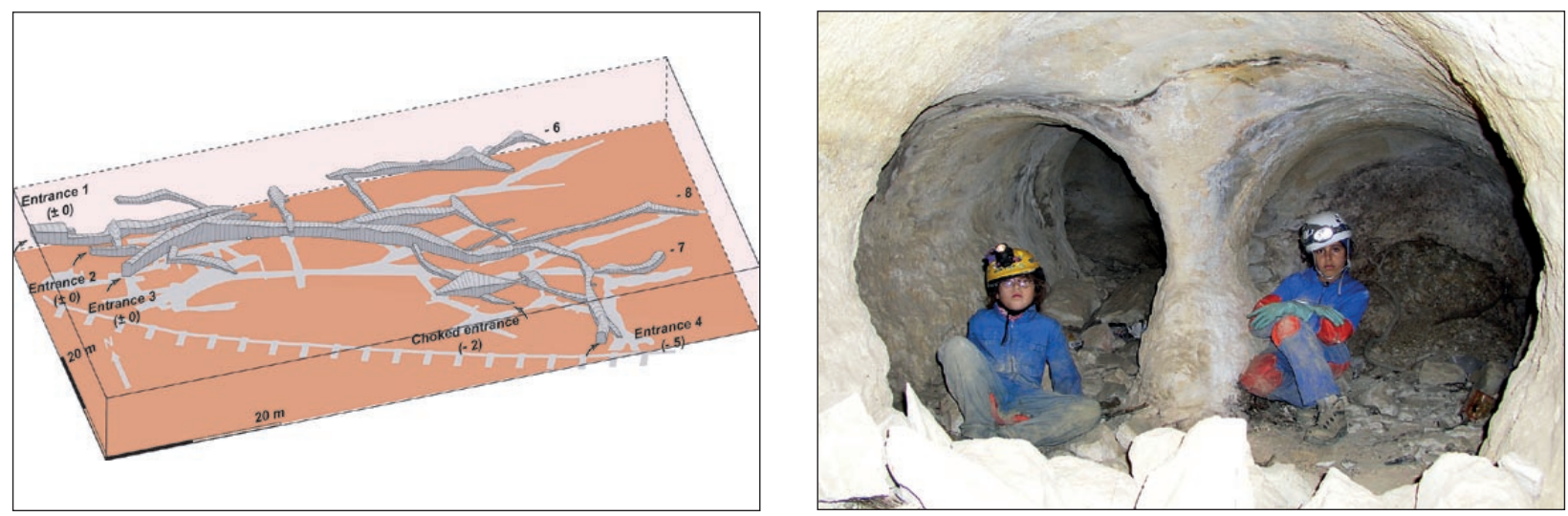

Fig. 37: The cave of Saint-Sébastien (Gréoux-les-Bains, Alpes-de-Haute-Provence) is a 2D maze. It is an inclined planar maze confined below a marly ceiling. Dip is oriented toward the SE, the thermal water rose toward the NW (toward left on the sketch).

resulting from the main speleogenetic phase is a dense network of enlarged discontinuities, similar to the previous examples. However, an origin by rising water is strongly debated. The limited stratigraphic range of the caves, and also their location almost entirely beneath thin overlying sandstone strata, argue for an origin by mixing between groundwater from the limestone outcrops and diffuse infiltration from above. (Palmer et al. 2016). Caves are concentrated along zones of Carboniferous paleokarst and early diagenetic alteration.

\section{$2 D$ maze caves}

If a significant permeability difference exists between two strata, and if no significant fracture is present, a 2D maze cave can develop in the more permeable bed and below the less impermeable ceiling (Fig. 37). The 2D maze cave is a subtype of 3D maze cave; some parts of 3D mazes locally develop as 2D mazes, when a less permeable stratum is present on the ceiling. The passages are horizontal or inclined, according to the dip. The Denis Parisis system in the central part of Paris basin is horizontal. In Monte

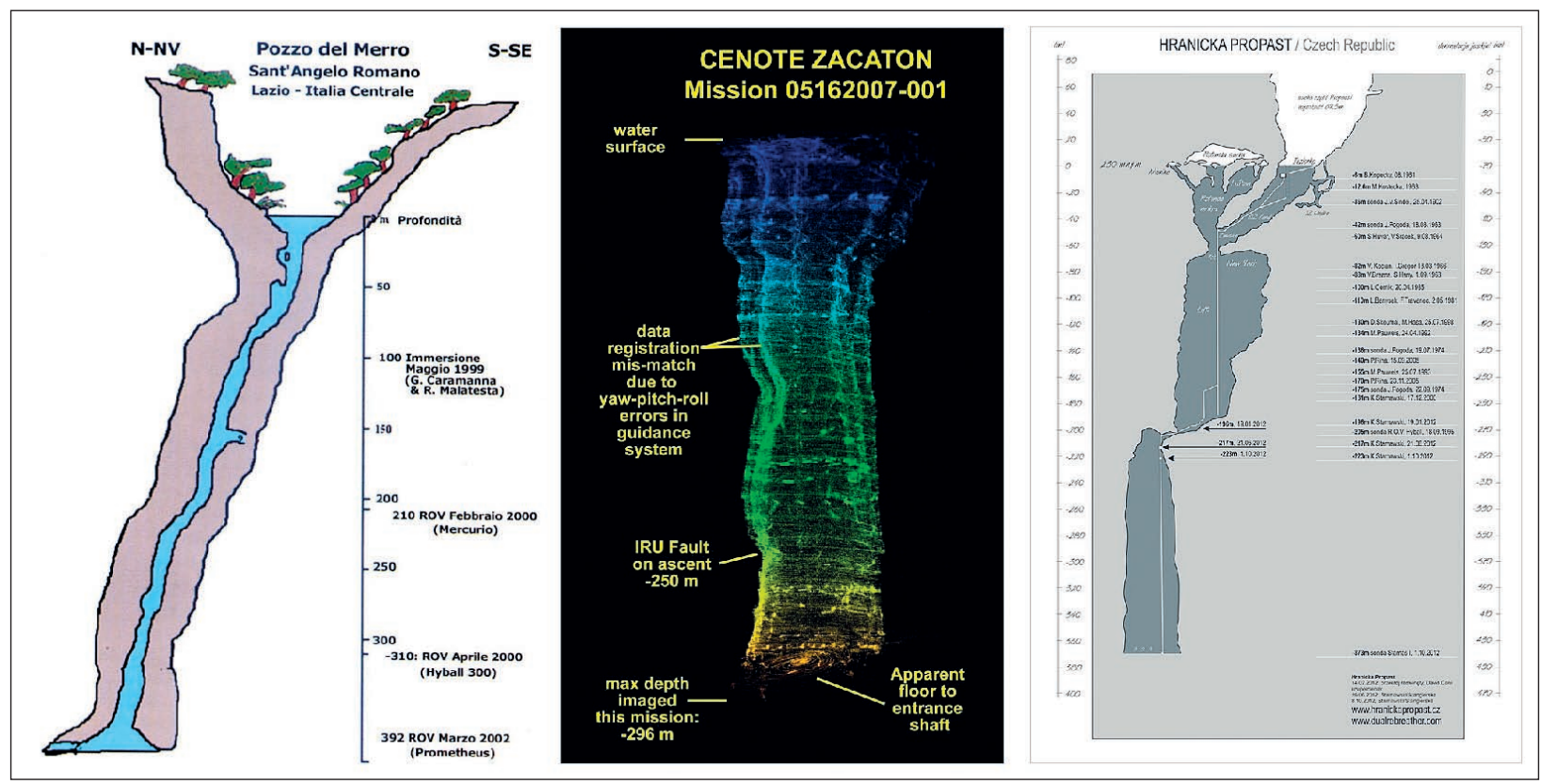

Fig. 38: Giant ascending shafts, the deepest such features in the world, are the result of "hyperkarst" processes around volcanic or active deep-rooted faults combining thermalism, degassing, and microbial activity. Pozzo del Merro, Italy, is more than $450 \mathrm{~m}$ deep including the collapse doline (Caramana 2002); Zacaton shaft, Mexico, survey using a 3D scanner (Gary 2000); Hranica propast, Czech Rep., focuses thermalism and $\mathrm{CO}_{2}$ degassing from deep-rooted fault (http://www.boinc.sk). Pozzo del Merro and Hranica propast are enlarged fractures, whereas Zacaton eventually evolved as a collapse shaft. 


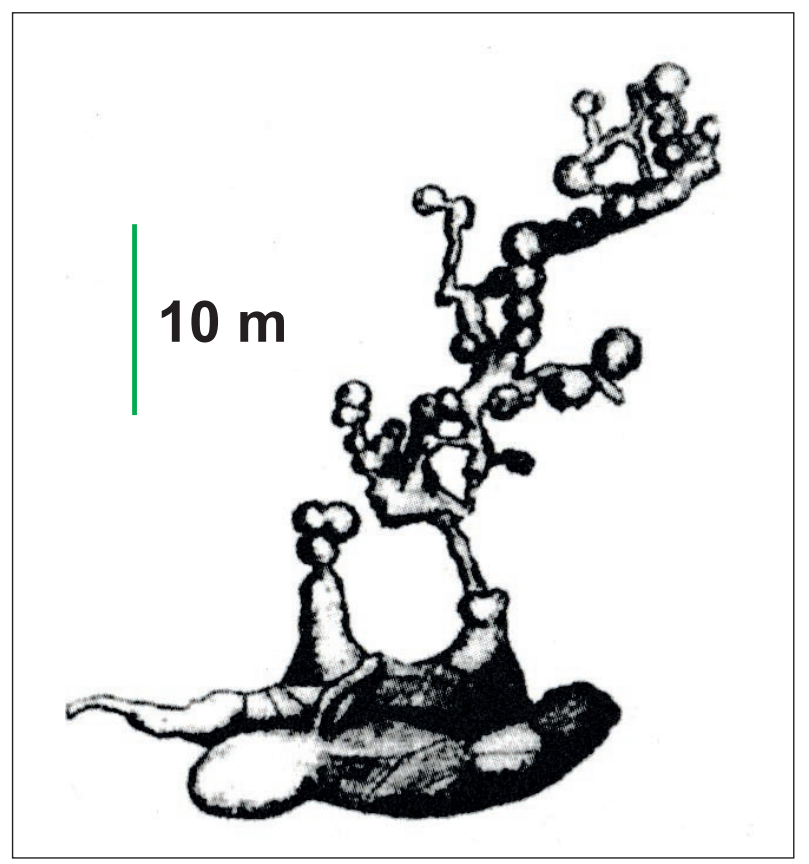

Fig. 39: Sátorkö-puszta, Hungary. The "model" of hydrothermal cave, stacked spheres made by convective processes of sulfuric condensation-corrosion (Ford \& Williams 2007).

Cucco, the Faggeto Tondo develops below the inclined marly cover.

\section{Giant ascending shafts}

In active tectonic areas, the combination of rising warm water, $\mathrm{CO}_{2}$ and $\mathrm{H}_{2} \mathrm{~S}$ outgassing, and microbial activity makes "hyperkarst" along major fault lines, producing the deepest ascending shafts of the world (Fig. 38).

\section{Hypogenic cave pattern along or above} the water table

At shallow depth along the water table, degassing, sulfide oxidation and mixing with oxygenated meteoric water produces strong dissolution. This corrosive process also propagates through the cave atmosphere above the water
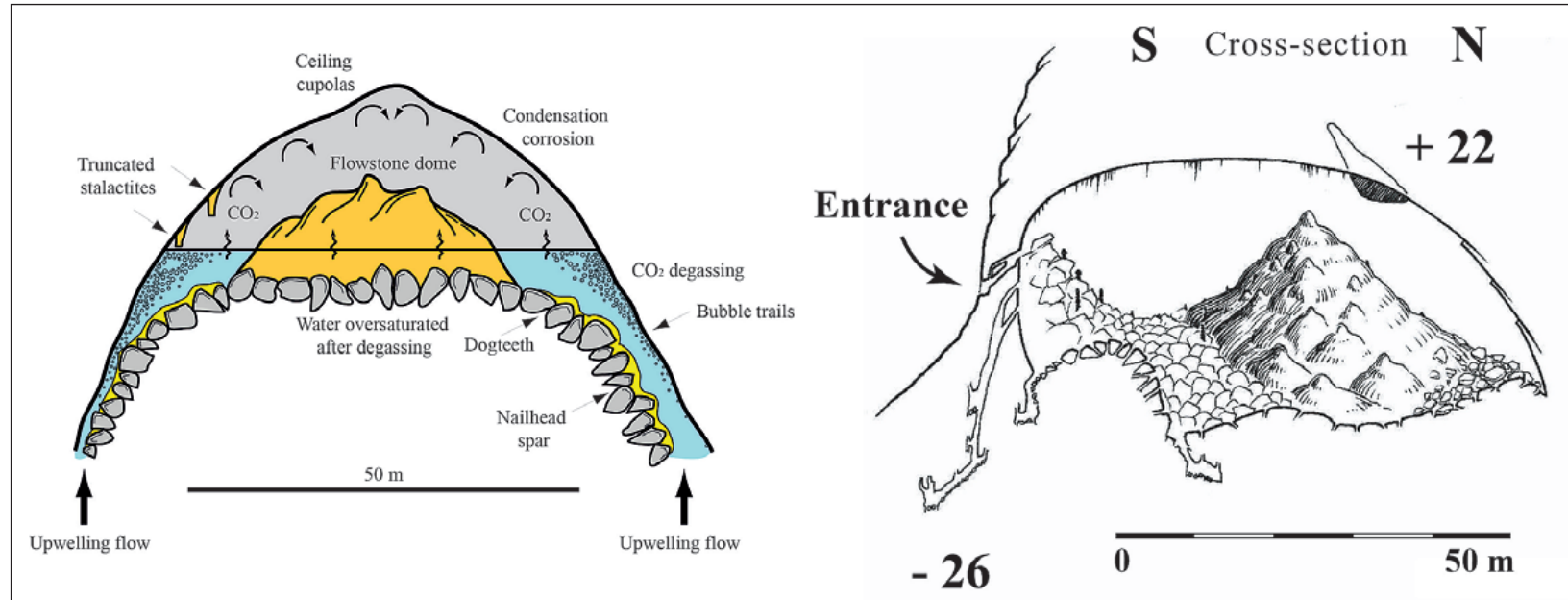

Fig. 40. The Champignons Cave, Provence, France, is an isolated chamber. Thermal hypogenic flow degassed CO at shallow depth. Thermal convection enhanced condensation-corrosion to develop a large isolated chamber more than $50 \mathrm{~m}$ wide, which tends toward a hemispherical shape. Simultaneously, massive calcite deposits occurred in the lake, which was supersaturated with calcite because of $\mathrm{CO}_{2}$ degassing (Audra et al. 2002).
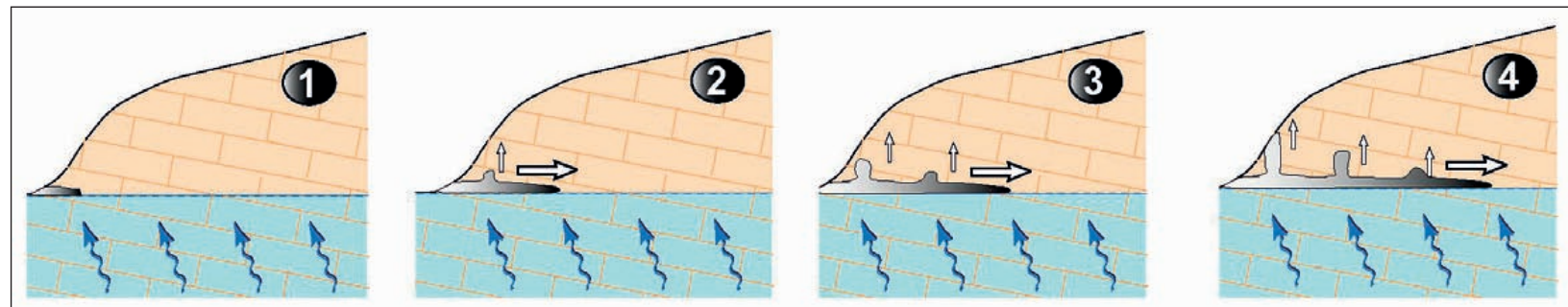

Fig. 41: A water-table sulfuric acid cave. Headward evolution by condensation-corrosion along the water table, supplied by major sulfuric upwelling along a fracture. Simultaneously, hydrothermal conditions lift the hot air so that condensation-corrosion occurs, bells and chimneys develop, and some finally break through to the surface. The white arrows indicate the direction of cave development; inspired by Villa Luz Cave, Mexico (Audra et al. 2009b, c). 


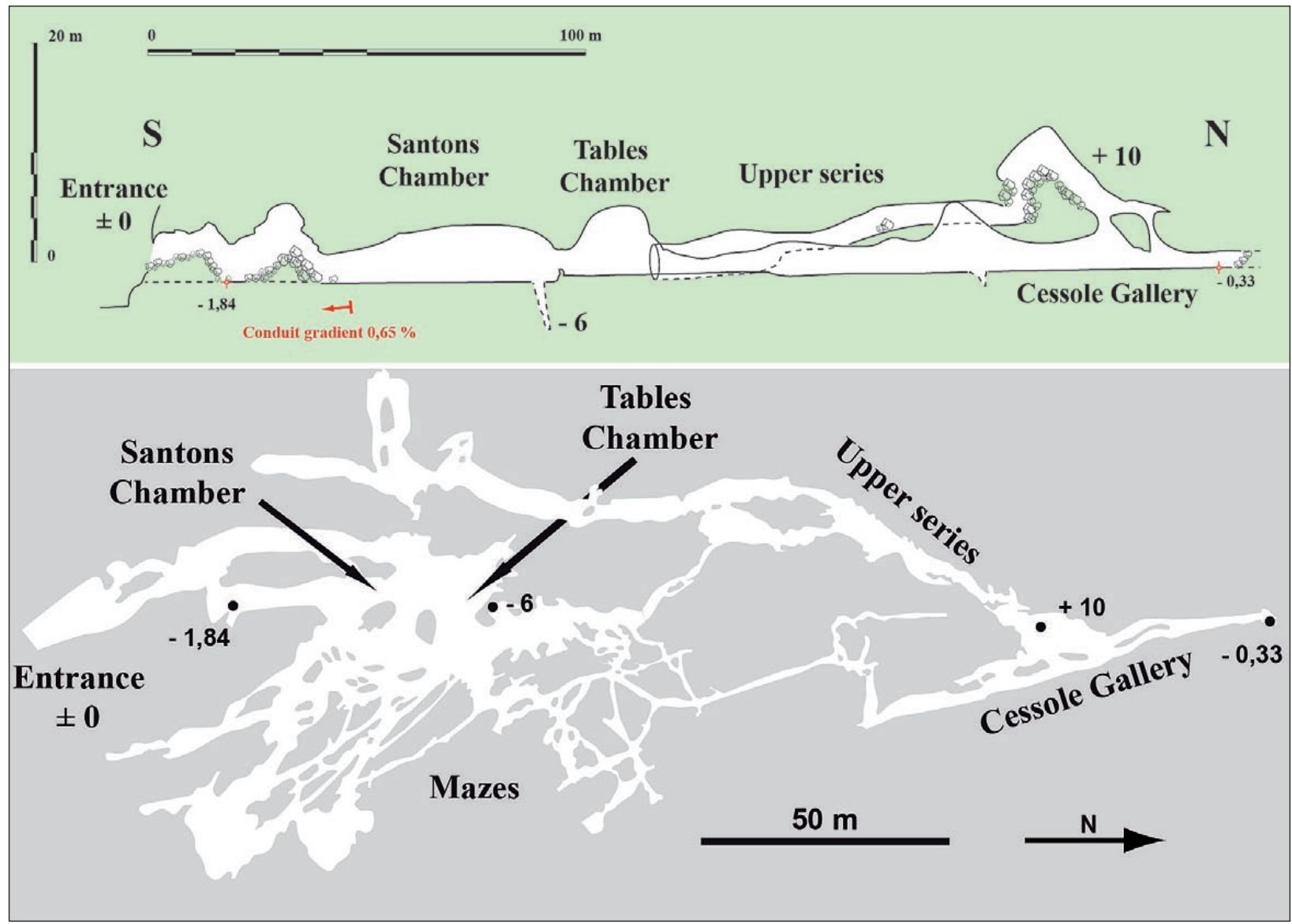

Fig. 42: Grotte du Chat, France. The longitudinal profile (top) shows a very low gradient $(<0.65 \%)$ made by sulfuric flow along the water table. A dead-end closes the passage upstream to the last sulfuric slot. The plan view (below) shows mazes, developed successively after lateral sliding of the flow toward the west, following very small base-level drops. The largest chambers in the center developed by integration of the neighboring mazes around the main sulfuric slots (Audra et al. 2009b, c; De Waele et al. 2016).

table by thermal air convection carrying aggressive droplets.

\section{Upwardly dendritic caves}

$\mathrm{CO}_{2}$ and $\mathrm{H}_{2} \mathrm{~S}$ degassing enhance aggressivity. By condensation-corrosion, cupolas develop upward as a dendritic pattern of stacked spheres (Audra et al. 2007). The development of two neighboring spheres will be divergent, toward the greatest potential heat transfer, because the rock in between the two spheres has less transfer potential and remains warm (Szunyogh 1990), giving the bush-like structure, as found in the Sátorkö-puszta Cave, Hungary (Fig. 39). Above thermal water, condensation occurs at the ceiling which is cooler.

\section{Isolated chambers}

When strong degassing occurs, upwardly dendritic spheres enlarge and merge, eventually producing large isolated chambers (Fig. 40) (Audra et al. 2002). Taking into account moderate thermal gradient and $\mathrm{pCO}_{2}$, mod- eling has shown that such volume can develop in a rather short time span, about 10000 years (Lismonde 2003). From examples in Israel, Frumkin and Fischhendler (2005) assign the origin of isolated chambers to phreatic convection.

\section{Water table sulfuric caves}

Above the water table, sulfuric vapors and thermal convections produce strong condensation-corrosion and replacement gypsum crusts (Egemeier 1981). The main drain develops headwards from springs (Fig. 41). Due to the sulfuric corrosion the long profile displays a tiny gradient (Fig. 42). Minor changes in base level cause the flow to migrate laterally forming incipient mazes (Audra 2007, 2009b, c). Condensation domes develop upward and may breach the surface (Fig. 41). The most demonstrative water table sulfuric cave are Cueva de Villa Luz (Hose and Pisarowicz 1999; Hose et al. 2000), Mexico; Chat Cave, France (De Waele et al. 2016); Kane Caves, Wyoming, USA (Egemeier 1981; Engel et al. 2004), Acqua Fitusa, Italy (De Waele et al. 


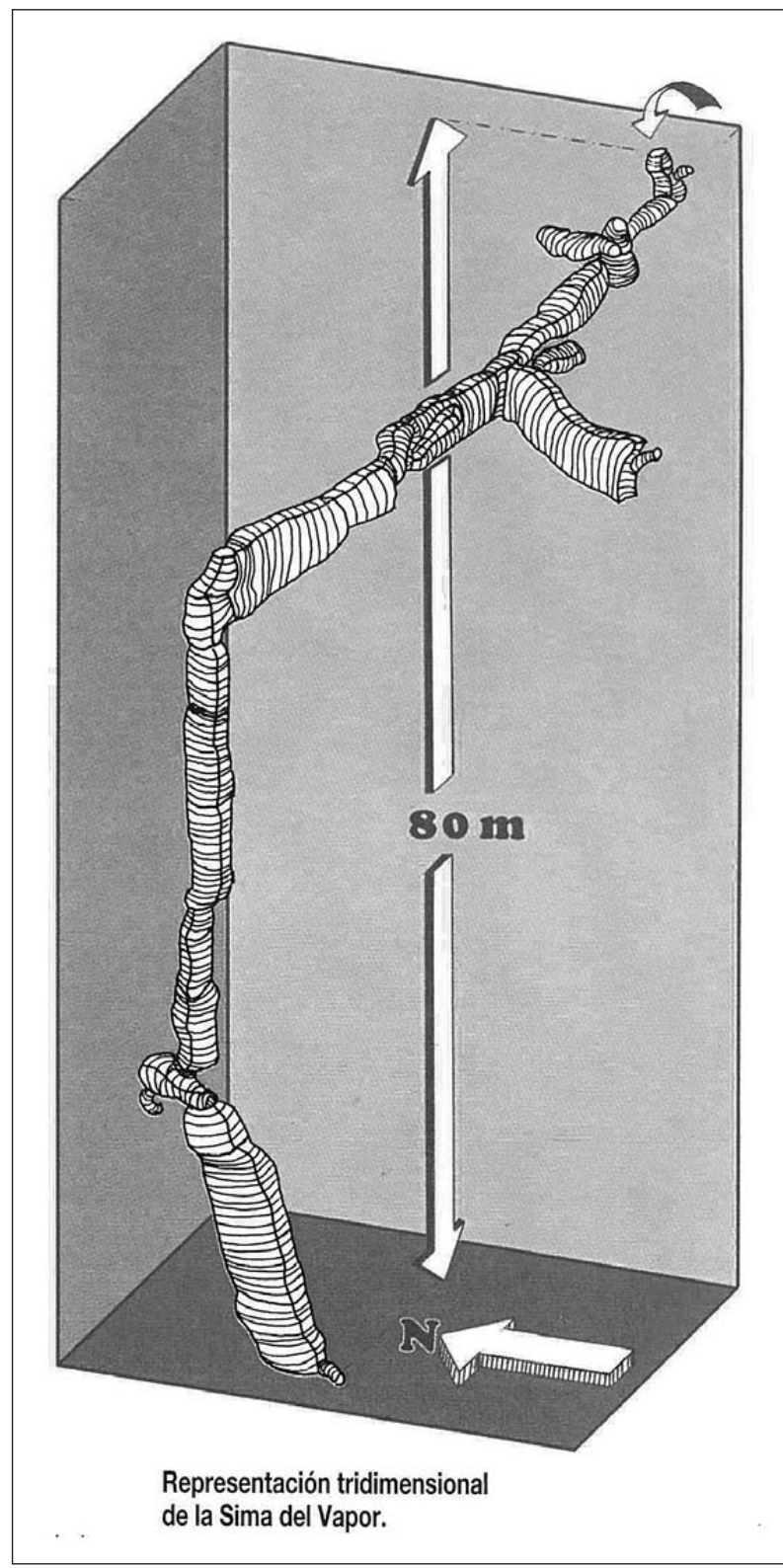

Fig. 43: Vapor shaft, Spain, is a "smoking shaft » made by warm rising air producing condensation-corrosion along a fracture while cooling. The cave air is warmed by the thermal aquifer located below (survey Cuatro Picos, Cartagena).
2016), Kraushöhle and Bad Deutsch Altenburg Caves in Austria (Plan et al. 2012; De Waele et al. 2016). In case of major base level lowering, successive horizontal cave levels develop: Frasassi Cave, Italy (Galdenzi \& Menichetti 1995; Galdenzi \& Maruoka 2003).

"Smoking" shafts in the vadose zone

Above thermal aquifers, the rock is significantly heated by the geothermal gradient. In winter the atmosphere of open shafts is unstable: the cold air sinks inside the shaft and expels outside the warm air of the shaft making it condense, giving the impression that the shaft is smoking. The rising warm air flow follows ceiling channels where condensation-corrosion focuses while cooling. Eventually, it produces condensation ceiling cupolas and channels, which could leading to their misinterpretation as phreatic in origin (Vapeur Shaft, France; Nasser Schacht, Austria; Fumarollas and Vapor Shafts, Spain). These shafts are generally guided by mechanical fractures (Fig. 43); the hypogenic role through thermal gradient and air convection is indirect and limited to the etching of the wall features.

The diversity of hypogenic caves is now placed in a global model, explaining main types of patterns, depending on the geological structure, the groundwater recharge, and the speleogenetic processes. In addition to hypogenic caves developed at depth by mixing corrosion and rising flow, some hypogenic caves are developing in the atmosphere at -or above- the water table, mainly by condensation-corrosion, and also corrosion by sulfuric and carbonic acids.

\section{CONCLUSION}

The understanding of speleogenesis has increased considerably in the past few decades, and this has helped to explain the pattern of caves, in both epigenic and hypogenic context. Regarding epigenic caves, the vertical pattern of cave levels may be related not only to successive base level lowering, but also to base level rises or alterna- tions of both. The Per Ascensum Model of Speleogenesis (PAMS) explains many deep phreatic systems discharging through vauclusian springs, not only around the Mediterranean affected by the Messinian Salinity Crisis, but also in any place where base level rise left its imprint, especially in coastal areas which have undergone 
regressions and transgressions, as well as glaciated areas, and subsident regions. Irregular recharge rates cause flooding in the epiphreatic zone, which results in looping caves, where the top of the loops indicates the maximal relief of the epiphreatic zone, which can be significantly above the base level. Water table caves are generally limited to places where a semi-impervious cover can regulate discharge and limit flooding, or in stable areas where evolution toward equilibrium allows the regularization of the long profile, especially by paragenetic processes resulting from sediment influx. The juvenile pattern offers a view of the initial stage of cave development.

Ghost-rock karstification must be investigated more thoroughly, since it is probably a widespread process producing maze patterns, especially in low relief areas such as plains and plateaus. The origin of ghost weathering is still under debate. Originally considered epigenic, it now appears to be more frequently hypogenic.

Regarding hypogenic speleogenesis, the concept of Regional Gravity Flow offers a framework explaining the location and the conditions of uprising flows that produce discrete caves in discharge areas. Cave patterns display 3D networks developed in the phreatic zone. The giant ascending shafts, which result from "hyperkarst" process combining deep-seated acids $\left(\mathrm{CO}_{2}+\mathrm{H}_{2} \mathrm{~S}\right)$, thermalism and microbial activity, are generally formed in active regions of volcanism or deep-rooted faults. Cave development along the water table points toward processes involving Sulfuric acid speleogenesis (SAS), where thermal air convection and condensation-corrosion play a key role, a process that has often been underestimated up to now.

Likely future directions for research will rely increasingly on analytical and modeling methods. The complex processes of hypogenic dissolution by flow mixing at depth remains to be investigated. Isotopic assessment will greatly enhance the understanding of enrichment/depletion processes and the origin of fluids. Dating will not only give insights into the chronology of speleogenesis, but will greatly help to correlate cave evolution phases to their corresponding environmental conditions. And field investigation will remain an important approach, especially in testing the effect of processes with a permanent balance between theoretical processes and resulting morphologies, in terms of cave features and patterns, as well as their scale.

\section{ACKNOWLEDGEMENTS}

The two anonymous reviewers have helped to improve this paper a lot.

\section{REFERENCES}

Audra, P., 1994: Karsts Alpins, Genèse de Grands Réseaux Souterrains. Exemples: le Tennengebirge (Autriche), l'Ile de Crémieu, la Chartreuse et le Vercors (France).- Karstologia Mémoires, 5, pp. 280.

Audra, P., 2001: L'organisation verticale des réseaux karstiques non confinés. Contrôle de la structure et du niveau de base. $-X I^{e}$ Congrès national suisse de spéléologie, Genève, 125-127.

Audra, P., 2007: Karst et spéléogenèse épigènes, hypogènes, recherches appliquées et valorisation.- Habilitation Thesis, University of Nice Sophia-Antipolis, pp. 278.
Audra, P. \& Hobléa, F. 1996: La traversée du Gébroulaz en Vanoise. Morphologie d'une cavité gypseuse de haute montagne. - In: International Congress, Alpine caves: alpine karst systems and their environmental context, Asiago 1992, 49-56.

Audra, P. \& Palmer, A.N. 2013: The vertical dimension of karst. Controls of vertical cave pattern.- In: Shroder J. (ed. in chief), Frumkin, A. (ed.) Treatise on Geomorphology, vol. 6 (Karst Geomorphology). Academic Press, 186-206, San Diego, CA.

Audra, P., Bigot, J.-Y. \& Mocochain, L., 2002: Hypogenic caves in Provence (France). Specific features and sediments.- Acta Carsologica, 3, 33-50. 
Audra, P., Mocochain, L., Camus, H., Gilli, E., Clauzon, G. \& Bigot, J.-Y., 2004: The effect of the Messinian deep stage on karst development around the Mediterranean Sea. Examples from southern France.Geodinamica Acta, 17/6, 27-38.

Audra, P., Hobléa, F., Bigot, J.-Y. \& Nobécourt, J.-Cl., 2007: The role of condensation-corrosion in thermal speleogenesis. Study of a hypogenic sulfidic cave in Aix-les-Bains.- Acta Carsologica, 2, 185-194.

Audra, P., Mocochain, L. \& Bigot, J.-Y., 2009a: Base level rise and per ascensum model of speleogenesis (PAMS): Interpretation of deep phreatic karsts, vauclusian springs and chimney-shafts.- In: Proceedings of $15^{\text {th }}$ International Congress of Speleology, Kerrville, Texas, 2, 788-794.

Audra, P., Mocochain, L., Bigot, J.-Y. \& Nobécourt, J.-C. 2009 b: The pattern of hypogenic caves.- In: Proceedings of $15^{\text {th }}$ International Congress of Speleology, Kerrville, Texas, 2, 795-800.

Audra, P., Mocochain, L., Bigot, J.-Y. \& Nobecourt, J.-C. 2009c: Hypogene cave patterns.- In: Klimchouk, A., Ford, D. (eds.) Hypogene Speleogenesis and Karst Hydrogeology of Artesian Basins. Special Paper, 1. Ukrainian Institute of Speleology and Karstology, 17-22, Kiev.

Audra, P., Lauritzen, S. E. \& Rochette, P. 2011: Speleogenesis in the hyperkarst of the Nakanai Mountains (New Britain, Papua New-Guinea). Evolution model of a juvenile system (Muruk Cave) inferred from U/Th and paleomagnetic dating). Speleogenesis and evolution of karst aquifer (SEKA), 11, 1, 6 pp.

Bayari, C.S., Pekka, E. \& Ozyurt, N.N., 2009: Obruks, as giant collapse dolines caused by hypogene karstification in central Anatolia, Turkey: Analysis of likely formation processes.- Hydrogeology Journal, 17, 327-345

Bella, P. \& Bosak, P. 2012: Speleogenesis along deep regional faults by ascending waters: case studies from Slovakia and Czech Republic.- Acta Carsologica, 41.2-3, 169-192

Bretz, J H., 1942: Vadose and phreatic features of limestone caverns.- Journal of Geology, 50, 675-811.

Brod, L.G, 1964: Artesian origin of fissure caves in Missouri.- National Speleological Society Bulletin, 26, 3, 83-112.

Bruthans, J. \& Zeman, O., 2003: Factors controlling exokarst morphology and sediment transport trough caves: comparison of carbonate and salt karst.- Acta Carsologica, 32, 1, 83-99.
Bruxelles, L. \& Wienin, M. 2009: Les fantômes de roche de la mine de la Grande Vernissière (Fressac, Gard). Premières observations sur l'origine de certains karsts de la bordure cévenole.- In: Actes du colloque AFK - Pierre Saint-Martin 2007, Karstologia Mémoires, 17, 192-200.

Bruxelles, L., Quinif, Y. \& Wienin, M., 2009: How can ghost rocks help in karst development?- $15^{\text {th }}$ International Congress of Speleology, Kerrville, 2, 814-818. www.karstportal.org

Camus, H. \& Bruxelles, L., 2013: Formes et couvertures karstiques des Avants-Causses du St-Affricain et du Causse du Guilhaumard. Rapport PROTEE PROR-2011-12 - In: Étude hydrogéologique des AvantsCausses du St-Affricain et du Causse Guilhaumard, GEOTER GTR-PNR-1212-1016.

Caramana, G., 2002: Exploring on of the world's deepest sinkholes: The Pozzo del Merro (Italy).- Underwater Speleology, February, 4-8.

Collignon, B., 1990: Les karsts hydrothermaux d’Algérie.In: $10^{\text {th }}$. International Congress of Speleology, Budapest 1989, III. Hungarian Speleological Society, 758760, Budapest.

Cunningham, K.J. \& Walker, C., 2009: Seismic-sag structures in Tertiary carbonate rocks beneath southeastern Florida, USA: evidence for hypogene speleogenesis?- In: Klimchouk, A.B., and Ford, D.C., (eds.) Hypogene Speleogenesis and Karst Hydrogeology of Artesian Basins. Ukrainian Institute of Speleology and Karstology, Special Paper, 1, 151-158, Simferopol, Ukraine.

Davies, W.E., 1960: Origin of caves in folded limestone.National Speleological Society Bulletin, 22, 5-18.

Davis, W.M., 1930: Origin of limestone caverns.- Geological Society of America Bulletin, 41, 475-628.

De Waele, J., Audra, P., Madonia, G., Vattano, M., Plan, L., D'Angeli, I.M., Bigot, J.-Y. \& Nobécourt, J.-C., 2016: Sulphuric acid speleogenesis (SAS) close to the water table: examples from southern France, Austria, and Sicily.- Geomorphology 253 (2016) 452-467

Dreybrodt, W., 1990: The role of dissolution kinetics in the development of karst aquifers in limestone: A model simulation of karst evolution.- Journal of Geology, 98, 639-655.

Dreybrodt, W., 1996: Principles of early development of karst conduits under natural and man-made conditions revealed by mathematical analysis of numerical models.- Water Resources Research, 32, 2923-2935. 
Dreybrodt, W., Gabrovšek, F. \& Romanov, D., 2005: Processes of Speleogenesis: A Modeling Approach. Carsologica, ZRC Publishing, pp. $376+\mathrm{CD}$, Ljubljana.

Droppa, A., 1966: Untersuchungen der parallelität von Flussterrassen mit horizontalen Höhlen.- In: Proceedings of $3^{\text {rd }}$ International Congress of Speleology, Vienna, 5, 79-81.

Dubois, C., Quinif, Y., Baele, J.-M., Barriquand, L., Bini, A., Bruxelles, L., Dandurand, G., Havron, C., Kaufmann, O., Lans, B., Maire, R., Martin, J., Rodet, J., Rowberry, M. D., Tognini, P. \& Vergari, A., 2004: The process of ghost-rock karstification and its role in the formation of cave systems.- Earth Science Reviews, 131, 116-148

Dublyansky, Y.V., 2014: Hypogene speleogenesis - discussion of definitions.- In: A. Klimchouk, I. Sasowsky, J. Mylroie, S.A. Engel, and A.S. Engel (Eds.) Hypogene Cave Morphologies. Karst Waters Institute Special Publication, 18, 1-3, Leesburg, Virginia.

Egemeier, S. J. 1981: Cavern development by thermal waters.- NSS Bulletin,. 43, 2, 31-51.

Engel, A.S., Stern, L.A. \& Bennet, P.C., 2004: Microbial contributions to cave formation: new insights into sulfuric acid speleogenesis.- Geology, 32, 369-372.

Eröss, A., 2010: Characterization of fluids and evaluation of their effects on karst development at the Rózsadomb and Gellért Hill, Buda Thermal Karst, Hungary.- PhD thesis, Eötvös Loránd University, pp. 171.

Exley, S., 1994: Caverns Measureless to Man.- Cave Books, pp. 326, St. Louis.

Farrant, A. R., 2004: Paragenesis.- In: Gunn, J. (ed.) Encyclopedia of Caves and Karst Science. Fitzroy Dearborn, pp. 569-571, New York.

Farrant, A., Smart, P., Whitaker, F. \& Tarling, D., 1995: Long-term Quaternary uplift rates inferred from limestone caves in Sarawak, Malaysia.- Geology, 23, 357-360.

Farrant, A.R. \& Smart, P.L., 2011. Role of sediment in speleogenesis; sedimentation and paragenesis.Geomorphology, 134, 1-2, 79-93

Ford, D.C., 1971: Geologic structure and a new explanation of limestone cavern genesis.- Transactions of the Cave Research Group of Great Britain, 13, 81-94.

Ford, D.C. (Ed.), 1983: Castleguard cave and karst, Columbia Icefield area, Rocky Mountains of Canada.In: Symposium at $8^{\text {th }}$ International Congress of Speleology, Bowling Green, Kentucky, 1981, Arctic and alpine research, 15, 4, 425-560.
Ford, D.C., 1999: Perspectives in karst hydrogeology and cavern genesis.- In: A. Palmer, M. Palmer and I. Sasowsky (eds.) Karst modeling. Karst Waters Institute Special Publication, 5, 17-29.

Ford, D.C., 2006: Karst geomorphology, caves and cave deposits: A review of North American contributions during the past half century.- In: Harmon R.S. \& Wicks C.W. (Eds.) Perspectives on Karst Geomorphology, Hydrology and Geochemistry. GSA Special Paper, 404, pp. 1-14, Boulder, Colorado.

Ford, D.C., 2014: Perspectives on the 'Four-State Model' of cave genesis in the dimensions of length and depth.- [Online] Available from: http://speleogenesis.info/community/blog/post/?id=Perspectiveson-the-Four-State-Model-of-cave-genesis [Accessed 26 April 2015].

Ford, D.C. \& Ewers, R.O., 1978: The development of limestone cave systems in the dimensions of length and depth.- Canadian Journal of Earth Sciences, 15, 1783-1798.

Ford, D.C. \& Williams, P.W., 2007: Karst Hydrogeology and Geomorphology.- John Wiley and Sons, Ltd., pp. 562, Chichester, U.K.

Gallino, S. 2007: Hydrogéologie, géochimie et modélisation hydrodynamique-thermique d'un système thermo-minéral associé à un contact structural alpin (Aix-les-Bains, Savoie).- $\mathrm{PhD}$ thesis, University of Savoie, pp. 339.

Gàzquez, F., Calaforra, J.-M., Forti, P., De Waele, J. \& Sanna, L., 2015 : The role of condensation in the evolution of dissolutional forms in gypsum caves: Study case in the karst of Sorbas (SE Spain).- Geomorphology, 229, 100-111.

Frumkin, A., 1998: Salt cave cross-section and their paleoenvironmental implications.- Geomorphology, 23, 183-191.

Frumkin, A. \& Fischhendler, I., 2005: Morphometry and distribution of isolated caves as a guide for phreatic and confined paleohydrological conditions.- Geomorphology, 67, 3-4, 457-471.

Gabrovšek, F., 2000: Evolution of early karst aquifers: From simple principles to complex models.- Inštitut za razusjivanje krasa ZRC SAZU, pp. 150, Postojna.

Galdenzi, S. \& Menichetti, M., 1995: Occurrence of hypogene caves in a karst region: examples from central Italy.- Environmental Geology, 26, 39-47.

Galdenzi, S. \& Maruoka, T., 2003: Gypsum deposits in the Frasassi caves, Central Italy.- Journal of Cave and Karst Studies, 65, 111-125. 
Gary, M.O., 2010: Karst Hydrogeology and Speleogenesis of Sistema Zacatón, Tamaulipas, Mexico.- PhD thesis, University of Texas, Austin, pp. 114. AMCS Bulletin, 21, Association for Mexican Cave Studies, Austin.

Gary, M.O. \& Sharp, J.M., 2009: Volcanogenic karstification: implications of this hypogene process.- In: Stafford, K.W., Land, L., Veni, G. (eds.) Advances in Hypogene Karst Studies, NCKRI Symposium 1. National Cave and Karst Research Institute, pp. 27-39, Carlsbad, NM.

Geršl, M., Geršlová, E., Hypr, D., Kolejka, V., 2011: Subcrustal $\mathrm{CO}_{2}$ Flux Measurement in the Hranice Hydrothermal Karst.- In: $21^{\text {th }}$ Goldschmidt Conference "Earth evolution", Prague, 2011. European Association of Geochemistry, [Online] Available from: http://goldschmidt.info/2011/abstracts/G.pdf [Accessed 24 April 2015].

Granger, D.E. \& Fabel, D., 2005: Cosmogenic isotope dating.- In: D.C. Culver and W.B. White (eds.) Encyclopedia of Caves, Elsevier Academic Press, pp. 137-141, San Diego.

Granger, D.E., Fabel, D. \& Palmer, A.N., 2001: PliocenePleistocene incision of the Green River, Kentucky, determined from radioactive decay of cosmogenic ${ }^{26} \mathrm{Al}$ and ${ }^{10} \mathrm{Be}$ in Mammoth Cave sediments.- Geological Society of America Bulletin, 113, 825-836.

Grund, A., 1903: Die Karsthydrographie.- In: Geographisches Abhandlung herausgegeben von A. Penck, 7, $200 \mathrm{pp}$.

Guyonnet-Benaize, C., 2011: Modélisation numérique $3 D$ haute résolution des structures géologiques de la Moyenne Durance, Provence, SE France (Multi-scale $3 \mathrm{D}$ modeling of geological structures of Middel Durance fault region SE, FRANCE).- $\mathrm{PhD}$ thesis, AixMarseille University, pp. 182 p.

Häuselmann, P., 2002: Cave genesis and its relation to surface processes: Investigations in the Siebenhengte region (BE, Switzerland).- Ph.D. thesis, University of Bern, pp. 168.

Häuselmann, P. \& Granger, D.E., 2005: Dating of caves by cosmogenic nuclides: Method, possibilities, and the Siebenhengste example (Switzerland).- Acta Carsologica, 34, 43-50.

Häuselmann, P., Jeannin, P.-Y. \& Monbaron, M., 2003: Role of epiphreatic flow and soutirages in conduit morphogenesis: the Bärenschacht example (BE, Switzerland).- Zeitschrift für Geomorphologie, 47/2, 171-190.

Hill, C. A., 1987: Geology of Carlsbad cavern and other caves in the Guadalupe Mountains, New Mexico and Texas.- New Mexico Bureau of Mines and Mineral Resources, 117, pp. 1-150.
Hobléa, F., Gallino-Josnin, S. \& Audra, P., 2010: Genesis and functioning of the Aix-les-Bains hydrothermal karst (Savoie, France): past research and recent advances.- Bulletin de la Société Géologique de France, 181, 315-326.

Hose, L.D. \& Pisarowicz, J.A., 1999: Cueva de Villa Luz, Tabasco, Mexico: reconnaissance study of an active sulfur spring cave and ecosystem.- Journal of Cave and Karst Studies, 61, 13-21.

Hose, L.D., Palmer, A.N., Palmer, M.V., Northup, D.E., Boston, P.J. \& Duchene, H.R., 2000: Microbiology and geochemistry in a hydrogen-sulphide-rich karst environment.- Chemical Geology, 169, 399-423.

Katzer, F., 1909: Karst und Karsthydrographie.- Zur Kunde der Balkanhalbinsel, 8, pp. 94.

Kempe, S., 2014a: Hypogene limestone caves in Germany: geochemical background and regionality.- In: A. Klimchouk, I. Sasowsky, J. Mylroie, S.A. Engel, and A.S. Engel (eds.) Hypogene Cave Morphologies. Karst Waters Institute Special Publication, 18, pp. 48-56, Leesburg, VA.

Kempe, S., 2014b: How deep is hypogene? Gypsum caves in the South harz.- In: A. Klimchouk, I. Sasowsky, J. Mylroie, S.A. Engel, and A.S. Engel (eds.) Hypogene Cave Morphologies. Karst Waters Institute Special Publication, 18, pp. 57-64, Leesburg, VA.

Klimchouk, A.B., 1992: Large gypsum caves in the Western Ukraine and their genesis.- Cave Science, 19, 1, 3-11.

Klimchouk, A. B., 2000a: Speleogenesis of great gypsum mazes in the Western Ukraine.- In: Klimchouk, A. B., Ford, D. C., Palmer, A. and Dreybrodt, W., (eds.) Speleogenesis: Evolution of karst aquifers. National Speleological Society, pp. 261-273, Huntsville, AL.

Klimchouk, A. B., 2000b: Speleogenesis under deepseated and confined settings.- In: Klimchouk, A. B., Ford, D. C., Palmer, A. and Dreybrodt, W., (eds.) Speleogenesis: Evolution of karst aquifers. National Speleological Society, pp. 244-260, Huntsville, AL.

Klimchouk A., 2007: Hypogene speleogenesis. Hydrogeological and morphogenetic perspective.- NCKRI Special Paper Series, 1, National Cave and Karst Research Institute, pp. 77, Carlsbad.

Klimchouk, A.B., 2013a: Hypogene speleogenesis.- In: Shroder, J. (editor in Chief), Frumkin, A. (ed.), Treatise on Geomorphology, 6, Karst Geomorphology, Academic Press, pp. 220-240, San Diego, CA.

Klimchouk, A.B., 2013b: Hydrogeological approach to distinguishing hypogene speleogenesis settings.- In: International Symposium on Hierarchical Flow Systems in Karst Regions, Budapest, Hungary, Book of Abstracts, pp. 94. [Online] Available from: http://www.karstflow2013.org/?nic=boo [Accessed 24 April 2015]. 
Klimchouk, A.B., 2013c: Hypogene Speleogenesis, its hydrogeological significance and role in karst evolution.- Simferopol: DIP, - 180 pp. (in Russian). Available from: http://www.institute.speleoukraine. net/uisk_pages/download.php?id=12680 [Accessed 24 April 2015].

Krause, R.E. \& Randolph, R.B., 1989: Hydrology of the Floridan aquifer system in southeast Georgia and adjacent parts of Florida and South Carolina.- U.S. Geological Survey Professional Paper, 1403-D, pp. 65.

Land, L., 2003: Evaporite karst and regional groundwater circulation in the lower Pecos Valley.- In: K. S. Johnson and J.T. Neal (eds.) Evaporite Karst and Engineering / Environmental Problems in the United States, Oklahoma Geological Survey Circular, 109. Oklahoma Geological Survey,pp.227-232, Norman.

Lauritzen, S.-E. \& Lauritsen, A, 1995: Differential diagnosis of paragenetic and vadose canyons.- Cave and Karst Science, 21, 55-59.

Lauritzen, S.-E., Ive, A. \& Wilkinson, B., 1983: Mean annual runoff and the scallop flow regime in a subarctic environment.- British Cave Research Association Transactions, 10/2, 97-102.

Lismonde, B., 2003: Limestone wall retreat in a ceiling cupola controlled by hydrothermal degassing with wall condensation.- Speleogenesis and Evolution of Karst Aquifers, 1/4, pp. 3.

Martel, E. A., 1921: Nouveau traité des eaux souterraines.Librairie Octave Doin, pp. 838, Paris.

Mocochain L., Audra P., Clauzon G., Bellier O., Bigot J.-Y., Parize O. \& Monteil P., 2009: The effect of river dynamics induced by the Messinian Salinity Crisis on karst landscape and caves: Example of the Lower Ardèche River (mid Rhône valley).- Geomorphology, 106, 1, 46-61.

Nosike, L., 2009: Relationship between tectonics and vertical hydrocarbon leakage: a case study of the deep offshore Niger Delta.- PhD thesis, University of NiceSophia Antipolis, pp. 281.

Onac, B.P., Wynn, J.G. \& Sumrall, J.B., 2011: Tracing the sources of cave sulfates: a unique case from Cerna Valley, Romania.- Chemical Geology, 288, 105-114.

Osborne, R.A.L., H. Zwingmann, R. E. Pogson, \& D.M. Colchester., 2006: Carboniferous Cave Deposits from Jenolan Caves, New South Wales: implications for timing of speleogenesis and regional geology.Australian Journal of Earth Sciences, 53, 377-405

Palmer, A.N., 1987: Cave levels and their interpretation.National Speleological Society Bulletin, 49, 50-66.
Palmer, A.N., 1991: Origin and morphology of limestone caves.- Geological Society of America Bulletin, 103, $1-21$.

Palmer, A. N., 2000: Hydrogeologic control of cave patterns.- In: Klimchouk A., Ford D.C., Palmer A.N., \& Dreybrodt W. (eds.) Speleogenesis: Evolution of Karst Aquifers, pp. 77-90.

Palmer, A.N., 2007: Cave Geology.- Cave Books, pp. 454 pp., Dayton, $\mathrm{OH}$,

Palmer, A.N., 2013: Sulfuric acid caves.- In: Frumkin, A. (vol. ed.), Shroder, J., (ed. in chief) Treatise on Geomorphology, Elsevier, pp. 241-257.

Palmer, A.N. \& Audra, P., 2004: Patterns of caves.- In: Gunn, J. (ed.) Encyclopedia of Cave and Karst Science. Fitzroy Dearborn, pp. 573-574, London.

Palmer, A.N. \& Palmer, M.V., 2000: Hydrochemical interpretation of cave patterns in the Guadalupe Mountains, New Mexico.- Journal of Cave and Karst Studies, 62, 91-108.

Palmer, A. N. \& Palmer, M. V., 2000b: Speleogenesis of the Black Hills maze caves, South Dakota, USA.- In: Klimchouk A., Ford D. C., Palmer A. N. \& Dreybrodt W. (eds.) Speleogenesis. Evolution of karst aquifers. National Speleological Society, pp. 274-281, Huntsville

Palmer, A.N. \& Palmer, M.V., 2009: Caves and karst of the USA.- National Speleological Society, pp. 446, Huntsville, AL.

Palmer, A.N., Palmer, M.V., \& Paces, J.B., 2016: Geologic history of the Black Hills caves, South Dakota.Geological Society of America, Special Paper 516, in press.

Pasini, G., 2009: A terminological matter: paragenesis, antigravitative erosion or antigravitational erosion.International Journal of Speleology, 38, 129-138.

Piccini, L. \& Iandelli, N. 2011: Tectonic uplift, sea level changes and Plio-Pleistocene evolution of a coastal karst system: the Mount Saint Paul (Palawan, Philippines).- Earth Surface Processes and Landforms, 36, 5, 594-609

Piccini, L., De Waele, J., Galli, E., Polyak, V.J., Bernasconi, S.M. \& Asmerom, Y., 2015 : Sulphuric acid speleogenesis and landscape evolution: Montecchio cave, Albegna river valley (Southern Tuscany, Italy).- Geomorphology, 229, 134-143.

Plan, L., Tschegg, C., De Waele, J. \& Spötl, C., 2012: Corrosion morphology and cave wall alteration in an Alpine sulfuric acid cave (Kraushöhle, Austria).Geomorphology, 169/170, 45-54.

Polyak, V.J., McIntosh, W.C., Provencio, P. \& Güven, N., 1998: Age and origin of Carlsbad Caverns and related caves from ${ }^{40} \mathrm{Ar} /{ }^{39} \mathrm{Ar}$ of alunite.- Science, 279 , 1919-1922. 
Quinif, Y., 1994: Le puits de Flenu: la plus grande structure endokarstique du monde $(1200 \mathrm{~m})$ et la problématique des puits du Houiller (Belgique).- Karstologia, 24, 29-36.

Quinif, Y., 2010: Fantômes de roche et fantômisation Essai sur un nouveau paradigme en karstogenèse. Karstologia Mémoires, 18, pp. 196.

Renault, P., 1970: La Formation des Cavernes.- Presses Universitaires de France, pp. 127, Paris.

Sanna, L., Saez, F., Simonsen, S.L., Constantin, S., Calaforra, J.M., Forti, P. \& Lauritzen, S.-E., 2010: Uranium-series dating of gypsum speleothems: methodology and examples.- International Journal of Speleology, 39, 1, 35-46.

Sarbu, S. M. \& Lascu, C. 1997: Condensation corrosion in Movile cave, Romania.- Journal of Cave and Karst Studies, 59, 3, 99-102.

Sasowsky, I.D., 2005: Paleomagnetic record in cave sediments.- In: D.C. Culver and W.B. White (eds.) Encyclopedia of Caves. Elsevier Academic Press, pp. 427-431, San Diego.

Schmidt, V.A., 1982: Magnetostratigraphy of sediments in Mammoth Cave, Kentucky.- Science, 217, 827-829.

Spechler, R.M., 1994: Saltwater intrusion and quality of water in the Floridan aquifer system, northeastern Florida.- U.S. Geological Survey Water-Resources Investigations Report, 92-4174, pp. 76.

Swinnerton, A.C., 1932: Origin of limestone caverns.- Geological Society of America Bulletin, 43, 662-693.

Szanyi, G., Surányi, G. \& Leél-Őssy, S., 2012: Cave development and Quaternary uplift history in the Central Pannonian Basin derived from speleothem ages.- Quaternary Geochronology, 14, p. 18-25.

Szunyogh, G., 1990: Theoretical investigation of the development of spheroidal niches of thermal water origin - Second approximation.- In: Proceedings of the $10^{\text {th }}$ International Congress of Speleology, Budapest 1989, III, Hungarian Speleological Society, pp. 766-768, Budapest.

Thomas, C., 2010: Le karst du Yucatàn: rôle du flux géothermique, des failles, de l'eau de mer et des évaporites dans sa genèse.- Karstologia, 55, 1-18.
Tisato, N., Sauro, F., Bernasconi, S.M., Bruijn, R. \& De Waele, J., 2012: Hypogenic contribution to speleogenesis in a predominant epigenic karst system: a case study from the Venetian Alps, Italy.- Geomorphology, 151-152, 156-163.

Tóth, J. 1970: A conceptual model of the ground water regime and the hydrogeologic environment.- Journal of Hydrology, 10, 2, 164-176.

Tóth, J., 2009: Gravitational system of groundwater flow: Theory, Evaluation, Utilization.- Cambridge University Press, pp. 310.

Vergari, A., 1997: Contraintes paléokarstiques dans l'exploitation du calcaire carbonifère sur le bord nord $d u$ synclinorium de Namur en Hainaut occidental.- PhD thesis, Faculté polytechnique de Mons, pp. 268.

Vigna, B., Fiorucci, A., Banzato, C.,Forti, P. \& De Waele, J., 2010: Hypogene gypsum karst and sinkhole formation at Moncalvo (Asti, Italy). - Zeitschrift für Geomorphologie, Supplementary Issues, 54, 2, 285-306.

Vsevolozhskiy, V.A., 2007: Principles of Hydrogeology.Moscow University, pp. 448.

White, W.B. \& White, E.L., 2001: Conduit fragmentation, cave patterns, and the localization of karst groundwater basins: The Appalachians as a test case.- Theoretical and Applied Karstology, 13-14, 9-23.

Worthington, S.R.H., 2004: Hydraulic and geological factors influencing conduit flow depth.- Cave and Karst Science, 31, 123-134.

Worthington, S.R.H., 2005: Evolution of caves in response to base-level lowering.- Cave and Karst Science, 32, 3-12.

Wright, G. M. (ed.), 1984: The Western Canada sedimentary basin: a series of geological sections illustrating basin stratigraphy and structure.- Canadian Society of Petroleum Geologists and Geological Association of Canada, Calgary. 